\title{
Selective Modification of Peptides and Proteins at Tryptophan Using a Biomimetic Electron Transfer Process.
}

Samantha J. Tower, Wesley J. Hetcher, Tyler E. Myers, Nicholas J. Kuehl, and Michael T. Taylor*.

Department of Chemistry, University of Wyoming, Laramie, Wyoming, 82071

*mtaylo45@uwyo.edu

Supplementary Information 
Table of Contents

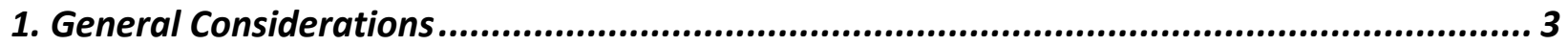

2. General Synthetic Procedures ...................................................................... 5

3. Peptide and Protein Irradiation Procedures............................................................ 13

4. Characterization of labelled protein conjugates by tandem mass spectrometry and circular

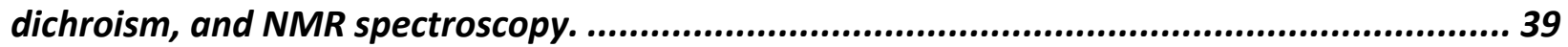

5. Mechanistic Studies ................................................................................. 54

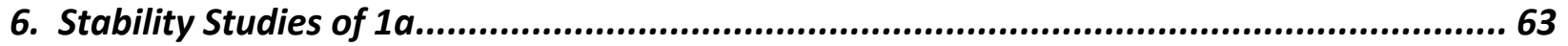

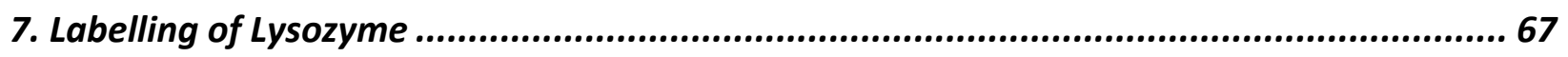

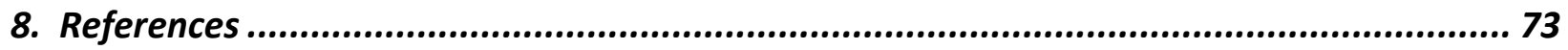

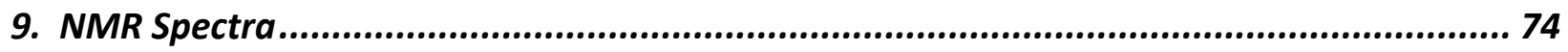




\section{General Considerations}

Nuclear magnetic resonance (NMR) spectra were acquired at ambient temperature using either a Bruker DRX-400 or an Avance III 600 spectrometer. Chemical shifts $(\delta)$ are reported in ppm and coupling constants $(\mathrm{J})$ are reported in $\mathrm{Hz}$. Data are reported in the following format: Chemical shift (multiplicity, coupling constants, number of protons). The following convention is used to report multiplicity: $s=$ singlet, $\mathrm{d}=$ doublet, $\mathrm{t}=$ triplet, $\mathrm{q}=$ quartet, $\mathrm{qn}=$ quintet, sext $=$ sextet, sept = septet, $\mathrm{m}=$ multiplet, $\mathrm{br}=$ broad. ${ }^{19} \mathrm{~F}-\mathrm{NMR}$ spectra were recorded using fluorobenzene $\left(\mathrm{C}_{6} \mathrm{H}_{5} \mathrm{~F}\right.$; $\delta \mathrm{F}=-115.3 \mathrm{ppm}$ in acetonitrile- $\left.\mathrm{d}_{3}\right)^{1}$ as an internal standard. Many of the pyridinium salts exist as rotamers. Where possible, NMR signals are assigned integration values equal to the number of protons associated with the given functional group of the given rotamer. Signals where rotameric peaks are overlapping are assigned hydrogens based directly on their integration values. Infrared (IR) spectra were collected on a Perkin Elmer Spectrum Two FT-IR equipped with an ATR probe. Absorptions are reported in wavenumbers $\left(\mathrm{cm}^{-1}\right)$. Analytical thin layer chromatography (TLC) was performed using Merck pre-coated glass backed silica gel plates (TLC Silica gel $60 \mathrm{~F} 254)$. TLC plates were visualized using either UV-light $(254 \mathrm{~nm})$, potassium permanganate or ceric ammonium molybdate staining solutions. Flash column chromatography was performed under positive pressure of compressed air using SiliCycle SiliaFlash ${ }^{2}$ P60 silica gel (230-400 mesh) unless otherwise stated. High-resolution mass spectra were obtained using a SCIEX 5800 MALDI TOF-TOF. MS/MS spectra were obtained on a Thermo Fisher Vanquish LTQ XL unless otherwise specified, with various conditions specific to each substrate analyzed. MS/MS spectra were processed using either Mmass or Lorikeet. Mass spectra were deconvolved using ThermoFisher Biopharma ${ }^{\mathrm{TM}}$ software and plotted using Prism. Absorption and emission spectra were acquired on a Jasco V-670 spectrophotometer. Circular dichroism spectra were acquired using an AVIV Biomedical Model 430 circular dichroism spectrometer.

Protein modification reactions were monitored and evaluated via LC/MS using a Thermo-Fisher Vanquish Flex LC coupled to a Thermo-Fisher LTQ XL ion trap mass spectrometer equipped with a heated ESI probe. Conversions were estimated using total ion count (TIC). Purification of labelled biomolecules was performed on a Thermo Fisher Dionex UltiMate 3000 semi-preparative HPLC.

Reactions which did not involve modification of proteins were performed in heat-dried glassware using appropriate Schlenk techniques. 2,4,6-trimethylpyrylium tetrafluoroborate was synthesized as reported previously ${ }^{2}$. Octreotide•OAc was purchased from Apex Bio, Leuprolide•OAc and Daptomycin were purchased from SelleckChem. Melittin (from honeybee venom, 85\% pure), Lysozyme (from chicken egg white, $>40,000$ units $/ \mathrm{mg}$ of protein) and Glucagon (European pharmacopeia standard) were purchased from Sigma Aldrich. All peptides and proteins were used without additional purification. All other reagents were purchased from commercial sources and used as received.

We gratefully acknowledge the Clennan research group for use of their Jasco V-670 spectrophotometer, the Basile group for assistance acquiring MALDI mass spectra, the Leonard group for assistance acquiring cyclic voltammetry data, and the Lehmann group for the assistance acquiring circular dichroism data. 


\section{General LC/MS methods:}

Method A. solvents: A: $0.1 \%$ formic acid in $\mathrm{H}_{2} \mathrm{O}$ B: $0.1 \%$ formic acid in $\mathrm{CH}_{3} \mathrm{CN}$, method: $20-70 \%$ B over $5 \mathrm{~min}, 70-90 \%$ B over $1 \mathrm{~min}, 90-20 \%$ B over $1 \mathrm{~min}$, then hold $20 \%$ B $3 \mathrm{~min}$, column: Kinetex® $1.3 \mu \mathrm{m}$ C18 $100 \AA$, LC Column $50 \times 2.1 \mathrm{~mm}$, m/z range: $500-2000$, flow rate: $0.2 \mathrm{~mL} / \mathrm{min}$.

Method B. solvents: A: $0.1 \%$ formic acid in $\mathrm{H}_{2} \mathrm{O}$ B: $0.1 \%$ formic acid in $\mathrm{CH}_{3} \mathrm{CN}$, method: $20-70 \%$ B over $5 \mathrm{~min}, 70-90 \%$ B over $1 \mathrm{~min}, 90-20 \%$ B over $1 \mathrm{~min}$, then hold $20 \%$ B $3 \mathrm{~min}$, m/z range: 500-2000, column: Aeris ${ }^{\mathrm{TM}} 3.6 \mu \mathrm{m}$ WIDEPORE XB-C18 20, LC Column $100 \times 21 \mathrm{~mm}$, flow rate: $0.2 \mathrm{~mL} / \mathrm{min}$.

Method C. solvents: A: $0.1 \%$ formic acid in $\mathrm{H}_{2} \mathrm{O}$ B: $0.1 \%$ formic acid in $\mathrm{CH}_{3} \mathrm{CN}$, method: $10-90 \%$ B over $1 \mathrm{~min}$, hold $90 \%$ B $2.5 \mathrm{~min}, 90-10 \%$ B over $0.5 \mathrm{~min}$, hold $10 \%$ B over $1 \mathrm{~min}, \mathrm{~m} / \mathrm{z}$ range: 100-300, column: Aeris ${ }^{\mathrm{TM}} 3.6$ um WIDEPORE XB-C18 20, LC Column $100 \times 21 \mathrm{~mm}$, flow rate: $0.3 \mathrm{~mL} / \mathrm{min}$.

Method D. solvents: A: $0.1 \%$ formic acid in $\mathrm{H}_{2} \mathrm{O}$ B: $0.1 \%$ formic acid in $\mathrm{CH}_{3} \mathrm{CN}$, method: $10-90 \%$ B over $1 \mathrm{~min}$, hold $90 \%$ B $2.5 \mathrm{~min}, 90-10 \%$ B over $0.5 \mathrm{~min}$, hold $10 \%$ B $1 \mathrm{~min}, \mathrm{~m} / \mathrm{z}$ range: $200-$ 800, column: Aeris ${ }^{\mathrm{TM}} 3.6 \mu \mathrm{m}$ WIDEPORE XB-C18 20, LC Column $100 \times 21 \mathrm{~mm}$, flow rate: 0.3 $\mathrm{mL} / \mathrm{min}$.

Method E. solvents: A: $0.1 \%$ formic acid in $\mathrm{H}_{2} \mathrm{O}$, B: $0.1 \%$ formic acid in $\mathrm{CH}_{3} \mathrm{CN}$, method: $10-40 \%$ B over 2 min, 40-90\% B over 1.5 min, hold $90 \%$ B 1 min, 90-10\% B over 30

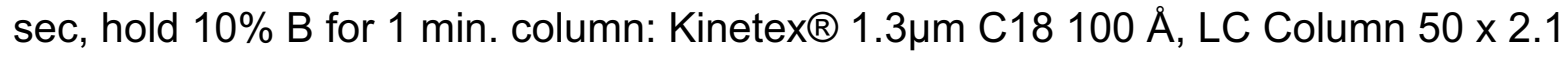
$\mathrm{mm}$, flow rate: $0.3 \mathrm{~mL} / \mathrm{min}$.

\section{General HPLC methods:}

HPLC Method A. solvents: A: $0.1 \%$ TFA in $\mathrm{H}_{2} \mathrm{O}$, B: $0.1 \%$ TFA in $\mathrm{CH}_{3} \mathrm{CN}$, method: hold $5 \%$ B 1 min, 5-35\% B over $28 \mathrm{~min}, 35-90 \%$ B over $1 \mathrm{~min}$, hold $90 \%$ B $2 \mathrm{~min}, 90-5 \%$ B over $1 \mathrm{~min}$, hold 5\% B 2 min, UV-Vis: 290, 280, 220 nm, column: Kinetex® $5 \mu \mathrm{m}$ C18 100 Å, LC Column 150 x $21.2 \mathrm{~mm}$, flow rate: $10 \mathrm{~mL} / \mathrm{min}$. 


\section{General Synthetic Procedures}

\section{General Procedure A: Synthesis of pyridinium salts}<smiles>Cc1cc(C)[o+]c(C(C)(Br)Br)c1</smiles>
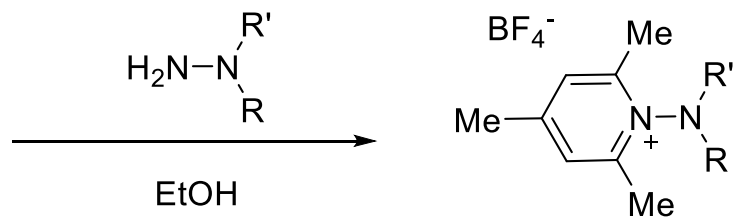

The synthesis of pyridinium salts was achieved by adapting the procedure of Studer ${ }^{2}$ as follows: A round-bottom flask equip with a stir bar and a side arm inlet adapter was heat dried under vacuum, allowed to cool to room temperature, and refilled with $\mathrm{N}_{2}$. The flask was charged with the pyrylium salt $(1 \mathrm{eq})$ and was then evacuated and refilled with $\mathrm{N}_{2}$. To the flask was added ethanol via syringe $(3.6 \mathrm{~mL} / \mathrm{mmol}$ pyrylium $)$, and the resulting mixture stirred vigorously. To the stirring solution was added the hydrazine (1.1 eq., $1 \mathrm{M}$ solution in ethanol) dropwise over 20 minutes, and the resulting solution was stirred vigorously at room temperature for 12-24 hours. The resultant mixture was then concentrated to dryness using a rotary evaporator. The resulting residue was redissolved in methylene chloride and extracted with a saturated aqueous sodium tetrafluoroborate solution a minimum of 3 times. The organic layer was dried over sodium tetrafluoroborate, filtered and concentrated using a rotary evaporator. The resulting residue was dissolved in methylene chloride-ethanol solution (2:1 v/v ratio), and then precipitated via dropwise addition of diethyl ether. The resulting solid was filtered, and the precipitate washed with additional ether and then dried to yield the desired pyridinium salt.

\section{1-((methoxycarbonyl)(methyl)amino)-2,4,6-trimethylpyridin-1-ium tetrafluoroborate (1a)}

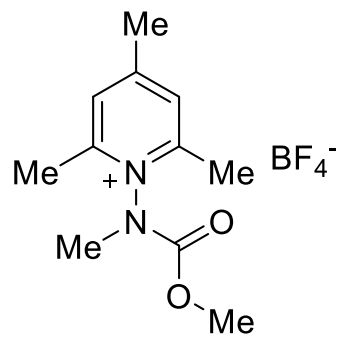

Salt 1a was synthesized by following general procedure A using Methyl 1-methylhydrazine-1carboxylate $^{10}(2.000 \mathrm{~g}, 19.21 \mathrm{mmol}), 2,4,6$-trimethyl pyrylium tetrafluoroborate (3.676 $\mathrm{g}, 17.51$ $\mathrm{mmol})$ and ethanol $(62 \mathrm{~mL})$. The reaction was allowed to stir for 18 hours at room temperature and was then directly filtered with no aqueous workup required to yield $1 \mathrm{a}$ as a white solid (3.737g, $82 \%$ yield). An additional crop of material was isolated by concentrating the filtrate under reduced pressure, dissolving the residue in methylene chloride-ethanol solution $(2: 1 \mathrm{v} / \mathrm{v}$ ratio) and precipitating via slow addition of diethyl ether to yield a yellow solid. The yellow solid was then redissolved in methylene chloride-ethanol solution (2:1 v/v ratio) and precipitated via slow addition of diethyl ether yielding a second batch of $1 \mathrm{a}$ for a combined yield of (4.548 $\mathrm{g}, 88 \%$ yield). $1 \mathrm{a}$ exists as a 1.2:1 mixture of rotamers at 300 Kelvin. 
${ }^{1} \mathrm{H}-\mathrm{NMR}\left(600 \mathrm{MHz}, \mathrm{CD}_{3} \mathrm{CN}\right)$ ס: $7.74(\mathrm{~s}, 2 \mathrm{H}), 3.92(\mathrm{~s}, 1.7 \mathrm{H}), 3.74(\mathrm{~s}, 3 \mathrm{H}), 3.50(\mathrm{~s}, 3 \mathrm{H}), 3.46(\mathrm{~s}, 3 \mathrm{H})$, $2.65(\mathrm{~s}, 6 \mathrm{H}), 2.60(\mathrm{~s}, 3 \mathrm{H})$.

${ }^{13} \mathrm{C}-\mathrm{NMR}\left(150 \mathrm{MHz}, \mathrm{CD}_{3} \mathrm{CN}\right) \delta: 162.1,162.1,157.3,157.1,153.6,152.2,128.7,117.4,54.854 .7$, $37.2,36.3,21.2,21.2,20.5,18.1,18.1$.

${ }^{19}$ F-NMR $\left(565 \mathrm{MHz}, \mathrm{CD}_{3} \mathrm{CN}\right) \delta:-152.1$.

FT-IR: 1714, 1636, 1572, 1478, 1352, 1328, 1276, 1214, 1175, 1056, 1020.

HR-MS (m/z) Found (M+): 209.0351, Calc'd $\mathrm{C}_{11} \mathrm{H}_{17} \mathrm{~N}_{2} \mathrm{O}_{2}{ }^{+} 209.1285$.

MP: $114-116^{\circ} \mathrm{C}$.

1-((tert-butoxycarbonyl)(methyl)amino)-2,4,6-trimethylpyridin-1-ium tetrafluoroborate (S1)<smiles></smiles>

Salt S1 was synthesized by following general procedure A with the following: Tert-butyl 1methylhydrazine-1-carboxylate $(2.003 \mathrm{~g}, 13.70 \mathrm{mmol}), 2,4,6$-trimethyl pyrylium tetrafluoroborate $(2.625 \mathrm{~g}, 12.50 \mathrm{mmol})$ and ethanol $(45 \mathrm{~mL})$. The reaction was allowed to stir for 18 hours at room temperature and was then directly filtered with no aqueous workup required to yield $\mathbf{S 1}$ as a white solid $(3.499 \mathrm{~g}, 83 \%$ yield). An additional crop of material was isolated by concentrating the filtrate under reduced pressure, dissolving the residue in methylene chloride-ethanol solution $(2: 1 \mathrm{v} / \mathrm{v}$ ratio) and precipitating via slow addition of diethyl ether to yield a yellow solid. The yellow solid was then redissolved in methylene chloride-ethanol solution $(2: 1 \mathrm{v} / \mathrm{v}$ ratio) and precipitated via slow addition of diethyl ether yielding a second batch of $\mathbf{S 1}$ for a combined yield of $(3.949 \mathrm{~g}, 93 \%$ yield). $\mathbf{S 1}$ exists as a 1.2:1 mixture of rotamers at 300 Kelvin.

${ }^{1} \mathrm{H}-\mathrm{NMR}\left(400 \mathrm{MHz}, \mathrm{CD}_{3} \mathrm{CN}\right)$ d: $7.71(\mathrm{~s}, 2 \mathrm{H}), 7.70(\mathrm{~s}, 2 \mathrm{H}), 3.44(\mathrm{~s}, 3 \mathrm{H}), 3.40(\mathrm{~s}, 3 \mathrm{H}), 2.65(\mathrm{~s}, 6 \mathrm{H})$, $2.63(\mathrm{~s}, 6 \mathrm{H}), 2.60(\mathrm{~s}, 6 \mathrm{H}), 1.57(\mathrm{~s}, 9 \mathrm{H}), 1.38(\mathrm{~s}, 9 \mathrm{H})$.

${ }^{13} \mathrm{C}-\mathrm{NMR}\left(150 \mathrm{MHz}, \mathrm{CD}_{3} \mathrm{CN}\right) \delta: 161.9,161.8,157.2,156.9,151.8,150.2,128.7,128.6,85.2$, 84.9, 37.2, 35.5, 27.1, 26.9, $21.2(2 \mathrm{C}), 18.3,18.1$.

${ }^{19} \mathrm{~F}-\mathrm{NMR}\left(565 \mathrm{MHz}, \mathrm{CD}_{3} \mathrm{CN}\right) \mathrm{\delta}:-152.2$.

FT-IR 3080, 2977, 1722, 1639, 1344, 1163,1060, 1032, 1013.

HRMS (m/z) Found (M-BF $\left.{ }_{4}\right): 251.1486$, Calc'd $\mathrm{C}_{14} \mathrm{H}_{13} \mathrm{~N}_{2} \mathrm{O}_{2}{ }^{+} 251.1754$.

MP $139-140^{\circ} \mathrm{C}$. 


\section{2,4,6-trimethyl-1-(methyl(((5-)(3aS,4S,6aR)-2-oxohexahydro-1H-thieno[3,4-d]imidazol-4- yl)pentyl)oxy)carbonyl)amino)pyridin-1-ium tetrafluoroborate (S3)}
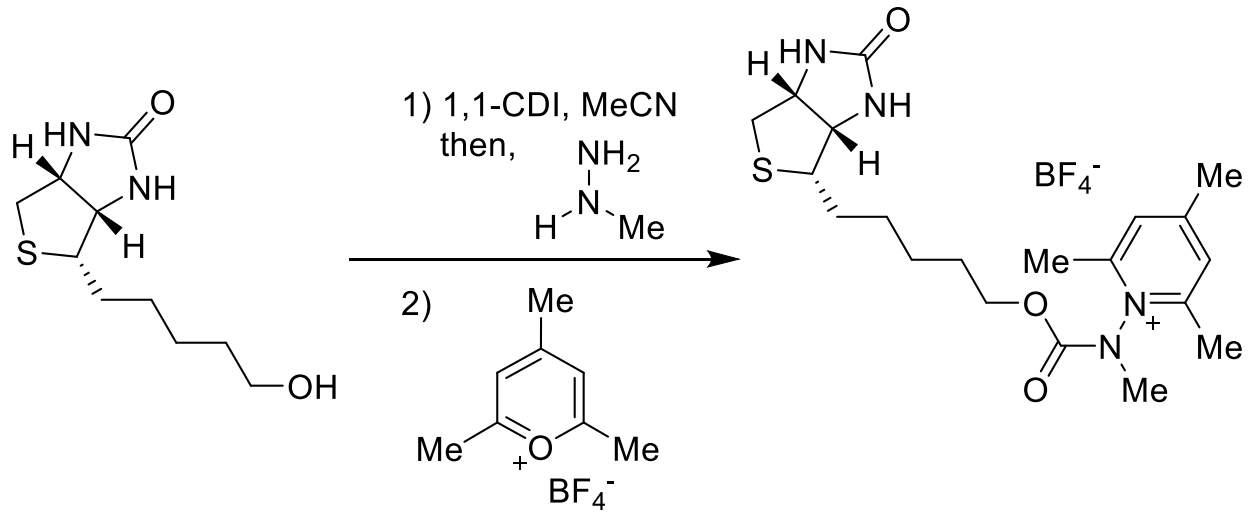

$\mathrm{EtOH}$

Pyridinium salt $\mathbf{S} \mathbf{3}$ was synthesized by adapting the procedure from Gaunt ${ }^{6}$ as follows: To a heatdried round-bottom flask, equip with a stir bar and a side arm inlet adapter, was added D-Biotin alcohol $^{7}(0.970 \mathrm{mg}, 4.21 \mathrm{mmol})$ and 1,1-carbonyldiimidizole $(1.023 \mathrm{~g}, 6.31 \mathrm{mmol})$. The flask was then evacuated and refilled with $\mathrm{N}_{2}$. This was followed by the addition of dry acetonitrile $(9.2 \mathrm{~mL})$ via syringe, and the reaction was allowed to stir vigorously for 4.5 hours at room temperature. An additional portion of dry acetonitrile $(5 \mathrm{~mL})$ was added followed by methyl hydrazine $(0.44 \mathrm{~mL}, 8.4$ $\mathrm{mmol}$ ), and the resultant mixture was allowed to stir vigorously for 3 hours at room temperature. The resulting suspension was filtered and washed with dry acetonitrile to afford a solid. The solid was washed twice in $20 \mathrm{~mL}$ dry acetonitrile-diethyl ether solution (1:1 v/v ratio) and filtered to afford a white solid that was directly used in the synthesis of pyridinium salt S3. The identity of the crude hydrazide intermediate $\mathbf{S 2}$ was confirmed via ${ }^{1} \mathrm{H}-\mathrm{NMR}$ and LC/MS.

${ }^{1} \mathrm{H}-\mathrm{NMR}\left(600 \mathrm{MHz}, \mathrm{CD}_{3} \mathrm{OD}\right) \mathrm{\delta}: 4.51$ (dd, J=5.0, $\left.7.9 \mathrm{~Hz}, 1 \mathrm{H}\right), 4.33$ (dd, J=4.4, $\left.7.9 \mathrm{~Hz}, 1 \mathrm{H}\right), 4.16-$ 4.06 (m, 2H), 3.27-3.19 (app. m, 1H), 3.10 (s, 3H), 2.95 (dd, J=5.0, $12.5 \mathrm{~Hz}, 1 \mathrm{H}$ ), 2.73 (d, $\mathrm{J}=12.7 \mathrm{~Hz}, 1 \mathrm{H}), 1.81-1.27(\mathrm{~m}, 10 \mathrm{H})$.

LC/MS (m/z) Found (M+H): 303.3, Calc'd $\mathrm{C}_{12} \mathrm{H}_{23} \mathrm{~N}_{4} \mathrm{O}_{3} \mathrm{~S}^{+}$303.2.

To a heat-dried round-bottom flask, equip with a stir bar and a side arm inlet adapter, was added the crude hydrazide $(0.221 \mathrm{~g}, 0.731 \mathrm{mmol})$ and 2,4,6-trimethylpyrylium tetrafluoroborate $(0.140$ $\mathrm{g}, 0.660 \mathrm{mmol})$. The flask was then evacuated and refilled with Ar. This was followed by the addition of ethanol $(2.3 \mathrm{~mL})$ via syringe, and the reaction was allowed to stir for 21 hours at room temperature. The reaction mixture was then concentrated under reduced pressure to yield a residue that was dissolved in methylene chloride-ethanol solution (2:1 v/v ratio), and precipitated via dropwise addition of diethyl ether $(\sim 1 \mathrm{~mL})$. The mother liquor was decanted, and the resultant oily residue was concentrated under reduced pressure to afford a yellow solid. The yellow solid was dissolved in methylene chloride $(10 \mathrm{~mL})$, and washed with saturated $\mathrm{NaBF}_{4}$ (aq., $\left.1 \mathrm{~mL}\right)$. The layers were separated, and the aqueous layer was extracted with methylene chloride $(15 \times 10$ $\mathrm{mL})$. The combined organic layers were dried over $\mathrm{NaBF}_{4}$ and concentrated under reduced pressure to afford an orange oil. The resulting oil was dissolved in methylene chloride-ethanol solution (2:1 v/v ratio) and precipitated via slow addition of diethyl ether. The mother liquor was 
decanted, and the resultant oily residue was concentrated under reduced pressure to afford a pale orange solid $(0.066 \mathrm{~g}, 35 \%)$. S3 exists as a 1.2:1 mixture of rotamers at 300 Kelvin.

${ }^{1} \mathrm{H}-\mathrm{NMR}\left(400 \mathrm{MHz}, \mathrm{CD}_{3} \mathrm{CN}\right)$ ס: 7.73 (s, 2H), 7.72 (s, 2H), 5.07 (bs, 2H), 4.46 (app

$\mathrm{m}, 2 \mathrm{H}), 4.31(\mathrm{t}, J=6.4 \mathrm{~Hz}, 2 \mathrm{H}), 4.29-4.21(\operatorname{app~m}, 2 \mathrm{H}), 4.17(\mathrm{t}, J=6.2 \mathrm{~Hz}, 2 \mathrm{H}), 3.50(\mathrm{~s}, 3 \mathrm{H}), 3.45$ $(\mathrm{s}, 3 \mathrm{H}), 3.21(\operatorname{app} \mathrm{m}, 1 \mathrm{H}), 3.12(\operatorname{app} \mathrm{m}, 1 \mathrm{H}), 2.96-2.87(\operatorname{app~m}, 2 \mathrm{H}), 2.66(\mathrm{~s}, 6 \mathrm{H}), 2.65(\mathrm{~s}, 6 \mathrm{H})$, $2.62(\mathrm{~s}, 3 \mathrm{H}), 2.61(\mathrm{~s}, 3 \mathrm{H}), 2.29(\mathrm{bs}, 2 \mathrm{H}), 1.84-1.10(\operatorname{app~m}, 18 \mathrm{H})$.

${ }^{13}$ C-NMR (150 MHz, CD $\left.{ }_{3} \mathrm{CN}\right)$ ס: 163.1, 162.1 (2C), 157.2, 157.1 (2C), 153.1, 151.6, 128.7, 68.4, $68.1,65.3,61.7,60.0,55.5,55.4,40.1,40.0,37.2,36.1,28.4,28.2,28.1,27.8,25.4,25.3,21.3$ (2C), 18.3, 18.1, 14.6.

${ }^{19}$ F-NMR (376 MHz, $\left.\mathrm{CD}_{3} \mathrm{CN}\right)$ ס: 150.68, -150.73, -152.2, -152.3.

FT-IR 3400, 3259, 3072, 2930, 1729, 1697, 1635, 1457, 1339, 1319, 1269, 1195, 1174, 1052, $1031,871,760,519$.

HRMS (m/z) Found (M-BF 4 ): 407.2036, Calc'd $\mathrm{C}_{20} \mathrm{H}_{31} \mathrm{~N}_{4} \mathrm{O}_{3} \mathrm{~S}^{+} 407.2111$.

MP $105-109^{\circ} \mathrm{C}$ (Decomposition).

\section{1-(((((rel-1r,4r)-4-((tert-butoxycarbonyl)amino)cyclohexyl)oxy)carbonyl)(methyl)amino)- 2,4,6-trimethylpyridin-1-ium tetrafluoroborate (1b)}

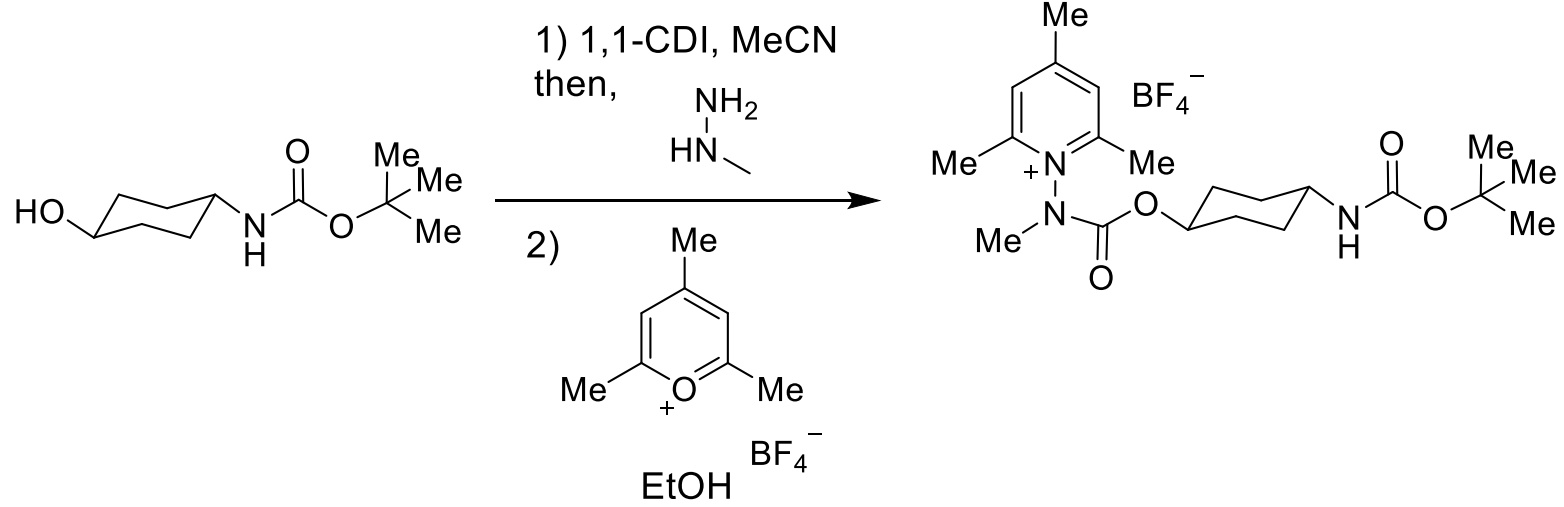

Salt $1 \mathrm{~b}$ was synthesized by adapting the procedure from Gaunt ${ }^{6}$ as follows: To a heat-dried roundbottom flask, equip with a stir bar and a side arm inlet adapter, was added tert-butyl $((1 \mathrm{r}, 4 \mathrm{r})-4-$ hydroxycyclohexyl)carbamate $(2.362 \mathrm{~g}, 10.97 \mathrm{mmol})$ and 1,1-carbonyldiimidizole $(2.684 \mathrm{~g}, 16.55$ $\mathrm{mmol})$. The flask was evacuated and refilled with Ar. This was followed by the addition of dry acetonitrile $(22 \mathrm{~mL})$ via syringe and the reaction was allowed to stir vigorously for 3 hours at room temperature. $N$-methyl hydrazine $(1.160 \mathrm{~mL}, 22.03 \mathrm{mmol})$ was added and the resulting solution was allowed to stir for 3 hours. The reaction mixture was then concentrated under reduced pressure to afford an orange solid, which was dissolved in dichloromethane $(20 \mathrm{~mL})$ and washed with aqueous $\mathrm{NaHCO}_{3}(10 \times 5 \mathrm{~mL})$. The organic layer was concentrated under reduced pressure, and the resulting, crude hydrazine was used directly in the synthesis of pyridinium salt $\mathbf{1} \mathbf{b}$. The identity of the crude hydrazide intermediate $\mathbf{S 4}$ was confirmed via ${ }^{1} \mathrm{H}-\mathrm{NMR}$ and LC/MS. 
${ }^{1} \mathrm{H}-\mathrm{NMR}\left(400 \mathrm{MHz}, \mathrm{CD}_{3} \mathrm{CN}\right)$ d: 5.21 (bs, 1H), 4.59-4.45 (app. m, 1H), 4.18 (s, 1H), 3.39 (bs, 1H), $3.01(\mathrm{~s}, 1 \mathrm{H}), 1.54-1.20(\mathrm{~m}, 15 \mathrm{H})$.

LC/MS (m/z) Found (M+Na): 310.3 , Calc'd $\mathrm{NaC}_{13} \mathrm{H}_{25} \mathrm{~N}_{3} \mathrm{O}_{4}{ }^{+} 310.2$.

To a heat-dried round-bottom flask, equip with a stir bar and a side arm inlet adapter, was added the crude hydrazine $(1.263 \mathrm{~g}, 4.400 \mathrm{mmol})$ and 2,4,6-trimethyl pyrylium tetrafluoroborate $(0.839$ $\mathrm{g}, 4.000 \mathrm{mmol}$ ). The flask was then evacuated and refilled with $\mathrm{N}_{2}$. This was followed by the addition of dry ethanol $(15 \mathrm{~mL})$ via syringe, and the reaction was allowed to stir for 19 hours at room temperature. The reaction mixture was then concentrated under reduced pressure, redissolved in methylene chloride-ethanol solution $(2: 1 \mathrm{v} / \mathrm{v}$ ratio) and precipitated via slow addition of diethyl ether to afford a pale yellow solid $(1.714 \mathrm{~g}, 90 \%$ yield). $\mathbf{1 b}$ exists as a 1.1:1 mixture of rotamers at 300 Kelvin.

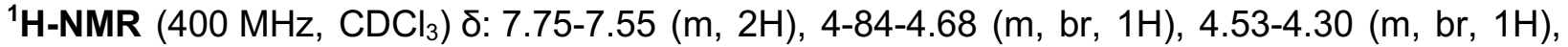
3.67-3.46 (m, br, 4H), 3.44-3.26 (m, br, 0.2H), 2.75-2.56 (m, 9H), 2.21-2.08 (m, br, 2H), 2.04-1.90 $(\mathrm{m}, \mathrm{br}, 1 \mathrm{H}), 1.74-1.59(\mathrm{~m}, \mathrm{br}, 1 \mathrm{H}), 1.55-1.40(\mathrm{~m}, 9 \mathrm{H}), 1.38-1.16(\mathrm{~m}, \mathrm{br}, 1 \mathrm{H})$.

${ }^{13}$ C-NMR (100 MHz, CD $\left.{ }_{3} \mathrm{CN}\right)$ ס: 162.0, 157.2, 157, 155.2, 152.5, 150.9, 128.7 (2C), 78.1, 76.9, $76.4,37.1,36.0,29.9,29.7,29.5,29.2,27.6(2 \mathrm{C}), 21.3,18.2,18.1$.

${ }^{19}$ F-NMR (565 MHz, $\left.\mathrm{CD}_{3} \mathrm{CN}\right) \delta:-152.298$.

FT-IR :3315, 3064, 2950, 1738, 1676, 1638, 1531, 1194, 1169, 1049, 1030, 901, 761.

HR-MS: (m/z) Found (M-BF $)$ : 392.2460, Calc'd $\mathrm{C}_{21} \mathrm{H}_{34} \mathrm{~N}_{3} \mathrm{O}_{4}{ }^{+} 392.2549$.

MP: $158-160.5^{\circ} \mathrm{C}$.

\section{1-((((rel-1r,4r)-4-ammoniocyclohexyl)oxy)carbonyl)(methyl)amino)-2,4,6-trimethylpyridin- 1-ium tetrafluoroborate (1c)}<smiles></smiles>

Salt 1c was prepared by adapting the procedure of Gonzalez-Sabín ${ }^{11}$ as follows: To a heat-dried round-bottom flask, equip with a stir bar and a side arm inlet adapter, was added with Salt 1b $(900 \mathrm{mg}, 1.88 \mathrm{mmol})$. The flask was then evacuated and refilled with Ar. This was followed by the addition of trifluoroacetic acid $(0.9 \mathrm{~mL}, 10.5 \mathrm{mmol})$ in methylene chloride $(0.9 \mathrm{~mL})$ via syringe, and the reaction mixture was allowed to stir for 2 hours at room temperature. The resulting mixture was concentrated under reduced pressure, dissolved in methylene chloride-ethanol solution (2:1 $\mathrm{v} / \mathrm{v}$ ratio) and precipitated via slow addition of diethyl ether. The mother liquor was decanted, and the resultant oily residue was concentrated under reduced pressure to afford a pale yellow solid (805 mg, $83 \%$ yield). 1c exists as a 1.1:1 mix of rotamers at 300 Kelvin. 
${ }^{1} \mathrm{H}-\mathrm{NMR}\left(400 \mathrm{MHz}, \mathrm{CD}_{3} \mathrm{CN}\right)$ ס: $7.72(\mathrm{~s}, 1 \mathrm{H}), 7.71(\mathrm{~s}, 1 \mathrm{H}), 7.55(\mathrm{~s}, \mathrm{br}, 2 \mathrm{H}), 4.81-4.63(\mathrm{~m}, 1 \mathrm{H}), 3.55-$ $3.40(\mathrm{~m}, 3 \mathrm{H}), 3.33-3.18(\mathrm{~m}, 1 \mathrm{H}), 3.15-3.03(\mathrm{~m}, 1 \mathrm{H}), 3.01-2.75(\mathrm{~m}, 1 \mathrm{H}), 2.71-2.54(\mathrm{~m}, 9 \mathrm{H}), 2.27-$ $2.09(\mathrm{~m}, 2 \mathrm{H}), 2.05-1.91(\mathrm{~m}, 1 \mathrm{H}), 1.75-1.48(\mathrm{~m}, 3 \mathrm{H}), 1.35-1.20(\mathrm{~m}, 1 \mathrm{H})$.

${ }^{13}$ C-NMR $\left(100 \mathrm{MHz}, \mathrm{CD}_{3} \mathrm{CN}\right) \delta: 162.1,157.2,156.9,152.4,150.8,128.7,75.9,75.4,49.1,48.9$, $37.1,36.0,28.7,28.4,27.5,27.4,21.3,18.2,18.1$.

${ }^{19} \mathrm{~F}-\mathrm{NMR}\left(565 \mathrm{MHz}, \mathrm{CD}_{3} \mathrm{CN}\right) \delta:-154.1$.

FT-IR: 3317, 3060, 2943, 1740, 1676, 1635, 1534, 1198, 1171, 1052, 1033.

HR-MS: (m/z) Found (M+): 292.9167 Calc'd $\mathrm{C}_{16} \mathrm{H}_{26} \mathrm{~N}_{3} \mathrm{O}_{2}{ }^{+} 292.2025$.

MP: $58-64^{\circ} \mathrm{C}$ (decomposed).

2,4,6-trimethyl-1-(methyl((((rel-1r,4r)-4-(pent-4ynamido)cyclohexyl)oxy)carbonyl)amino)pyridin-1-ium tetrafluoroborate (S5)<smiles></smiles><smiles></smiles>

To a heat-dried round-bottomed flask, equipped with a stir bar and a side arm inlet adapter, was added pyridinium salt 1c (free amine, $100 \mathrm{mg}, 0.19 \mathrm{mmol}$ ) and 2,5-dioxopyrrolidin-1-yl pent-4ynoate $(55 \mathrm{mg}, 0.29 \mathrm{mmol})^{9}$. The flask was then evacuated and refilled with Ar. To the flask was added methylene chloride $(1.9 \mathrm{~mL}, 0.1 \mathrm{M})$ via syringe, and the solution was stirred. To the stirring solution was added triethylamine $(52 \mu \mathrm{L}, 0.38 \mathrm{mmol})$ via syringe, in two portions, and the reaction mixture was allowed to stir for 7 hours at room temperature. The mixture was concentrated under reduced pressure to yield an oily residue that was dissolved in excess methylene chloride and extracted three times with $\mathrm{NaBF}_{4}$ (aq.). The organic layer was dried over $\mathrm{NaBF}_{4}$, filtered and concentrated under reduced pressure to afford an oily residue. The resultant oil was dissolved in methylene chloride and was precipitated via slow addition of diethyl ether to afford a dark pink oil, which was concentrated under reduced pressure to yield a pale pink solid (35 mg, 21\% yield). S5 exists as a 1.03:1 mix of rotamers at 300 Kelvin.

${ }^{1} \mathrm{H}-\mathrm{NMR}\left(400 \mathrm{MHz}, \mathrm{CD}_{3} \mathrm{CN}\right) \delta: 7.72(\mathrm{~s}, 2 \mathrm{H}), 7.71(\mathrm{~s}, 2 \mathrm{H}) 6.34(\mathrm{dd}, \mathrm{J}=6.82 \mathrm{~Hz}, \mathrm{~J}=18.76 \mathrm{~Hz}, 1$ $\mathrm{H})$, 4.87-4.67 (m, $1 \mathrm{H}), 3.80-3.70(\mathrm{~m}, 1 \mathrm{H}), 3.63-3.52(\mathrm{~m}, 1 \mathrm{H}), 3.52-3.48(\mathrm{~m}, 3 \mathrm{H}), 2.64-2.60(\mathrm{~m}, 9 \mathrm{H})$, 2.49-2.37 (m, 2H), 2.34-2.24 (m, 2H), 2.20-2.16 (m, 1H), 2.06-2.03 (m, 1H), 2.03-1.87 (m, 2H), $1.81-1.60(\mathrm{~m}, 2 \mathrm{H}), 1.44-1.24(\mathrm{~m}, 3 \mathrm{H})$.

${ }^{13}$ C-NMR (100 MHz, CD ${ }_{3} \mathrm{CN}$ ) ס: 170.0 (2C), 162.1, 157.2, 156.9, 152.5, 150.9, 182.7 (2C), 83.4 (2C), 76.9, 76.3, 68.9, 46.7, 46.5, 37.1, 35.9, 34.6 (2C), 29.4 29.2, 29.0, 28.9, 21.3, 18.2, 18.1, 14.3, 14.2. 
${ }^{19}$ F-NMR (565 MHz, $\left.\mathrm{CD}_{3} \mathrm{CN}\right)$ ס: -153.6.

FT-IR: 3386, 3274, 3076, 2940, 2865, 1730, 1661, 1636, 1346, 1200, 1049, 1030, 760, 645, 519.

HR-MS: (m/z) Found (M-BF 4 ): 372.2500, Calc'd $\mathrm{C}_{21} \mathrm{H}_{30} \mathrm{~N}_{3} \mathrm{O}_{3} 372.2287$.

MP: $58-64^{\circ} \mathrm{C}$ (decomposed).

\section{2,6-dimethyl-4-phenylpyrylium tetrafluoroborate (S6)}

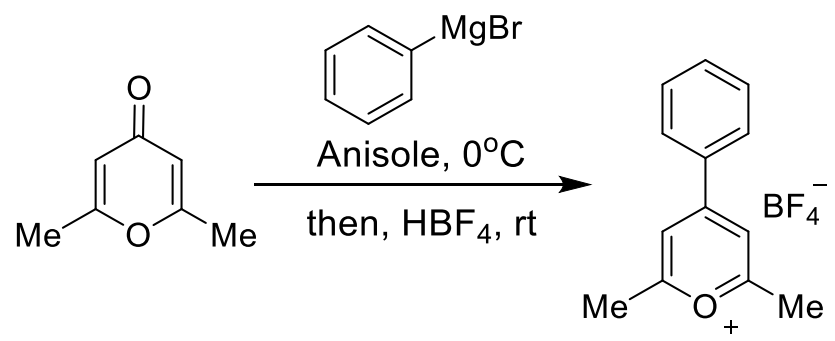

Salt $\mathbf{S} 6$ was prepared by adapting the procedure of Kozlowski ${ }^{4}$ as follows: To a heat-dried roundbottom flask, equip with a stir bar and a side arm inlet adapter, was added 2,6-dimethylpyrone $(4.642 \mathrm{~g}, 37.39 \mathrm{mmol})$. The flask was then evacuated and refilled with Ar. This was followed the addition of anisole $(32 \mathrm{~mL})$ via syringe. The solution was cooled to $0^{\circ} \mathrm{C}$ and phenylmagnesium bromide $(10.7 \mathrm{~mL}$ as a $3 \mathrm{M}$ solution in diethyl ether, $32.1 \mathrm{mmol}$ ) was added dropwise via syringe. The resultant purple solution was allowed to warm to room temperature, and tetrafluoroboric acid ( $8.0 \mathrm{~mL}$ as a $50 \%$ solution in ether, $54 \mathrm{mmol}$ ) was added. The reaction was stirred for 10 minutes and then diethyl ether $(25 \mathrm{~mL})$ was added. The reaction was then filtered and washed with diethyl ether followed by ethanol. The precipitate was dissolved in acetonitrile and precipitated via slow addition of diethyl ether to yield $\mathbf{S 6}$ as a light-purple solid (4.57 g, $52 \%$ yield).

${ }^{1} \mathrm{H}$ NMR: $\left(600 \mathrm{MHz}, \mathrm{CD}_{3} \mathrm{CN}\right) \delta: 8.19(\mathrm{~s}, 2 \mathrm{H}), 8.10$ (app d, J=7.5Hz, 2H), 7.85 (app t, J=7.4Hz, $1 \mathrm{H}), 7.74$ (app t, J=7.7Hz, 2H), $2.91(\mathrm{~s}, 6 \mathrm{H})$.

${ }^{13} \mathrm{C}$ NMR: $\left(100 \mathrm{MHz}, \mathrm{CD}_{3} \mathrm{CN}\right) \delta: 178.5,166.2,135.4,132.0,130.2,129.4,118.5,20.9$.

${ }^{19}$ F NMR: $\left(565 \mathrm{MHz}, \mathrm{CD}_{3} \mathrm{CN} / \mathrm{C}_{6} \mathrm{H}_{5} \mathrm{~F}\right) \delta:-149.8$.

FT-IR: 2926, 2339, 1727, 1635, 1591, 1487, 1377, 1334.

HRMS: (m/z) Found (M-BF4): 185.0836, Calc'd $\mathrm{C}_{13} \mathrm{H}_{13} \mathrm{O}^{+} 185.0961$.

MP: $202-203^{\circ} \mathrm{C}$ 
<smiles>COC(=O)N(C)[n+]1c(C)cc(-c2ccccc2)cc1C</smiles>

Salt 1d was synthesized by following general procedure A using the following: Methyl 1methylhydrazine-1-carboxylate $(0.90 \mathrm{~mL}, \quad 8.6 \mathrm{mmol}), \quad$ 2,6-dimethyl-4-phenylpyrylium tetrafluoroborate $(2.10 \mathrm{~g}, 7.70 \mathrm{mmol})$ and ethanol $(10 \mathrm{~mL})$. The reaction mixture was stirred for 18 hours at room temperature and was directly filtered with no aqueous workup required. The isolated solid was then dissolved in methylene chloride-ethanol solution $(2: 1 \mathrm{v} / \mathrm{v}$ ratio) and precipitated via slow addition of diethyl ether. This resulting precipitate was filtered and redissolved methylene chloride-ethanol solution $(2: 1 \mathrm{v} / \mathrm{v}$ ratio) and precipitated via slow addition of diethyl ether to yield salt $\mathbf{1 d}$ as an off-white solid $(2.10 \mathrm{~g}, 76 \%$ yield). $\mathbf{1 d}$ exists as a $1.2: 1$ rotameric ratio at 300 Kelvin.

${ }^{1} \mathrm{H}$ NMR: $\left(600 \mathrm{MHz}, \mathrm{CD}_{3} \mathrm{CN}\right) \delta: 8.18(\mathrm{~s}, 2 \mathrm{H}), 7.97(\mathrm{~d}, \mathrm{~J}=6.9 \mathrm{~Hz}, 2 \mathrm{H}), 7.76-7.64(\mathrm{~m}, 3 \mathrm{H}), 3.95(\mathrm{~s}$, $3 \mathrm{H}), 3.78(\mathrm{~s}, 3 \mathrm{H}), 3.54(\mathrm{~s}, 3 \mathrm{H}), 3.51(\mathrm{~s}, 3 \mathrm{H}), 2.76(\mathrm{~s}, 6 \mathrm{H})$.

${ }^{13} \mathrm{C}$ NMR: $\left(150 \mathrm{MHz}, \mathrm{CD}_{3} \mathrm{CN}\right) \delta: 158.3,158.1,157.6,157.5,153.6,152.2,133.6,133.5,132.8$, 132.7, 129.9, 129.6, 128.4 (2C), 125.1, 125.0, 54.8 (2C), 37.3, 36.4, 18.5, 18.4 .

${ }^{19}$ F NMR: $\left(565 \mathrm{MHz}, \mathrm{CD}_{3} \mathrm{CN} / \mathrm{C}_{6} \mathrm{H}_{5} \mathrm{~F}\right) \delta:-150.0$.

FT-IR: 2358, 1731, 1628, 1563, 1448, 1333.

HRMS: (m/z) Found (M-BF $\left.{ }_{4}\right): 271.1166$, Calc'd $\mathrm{C}_{16} \mathrm{H}_{19} \mathrm{~N}_{2} \mathrm{O}_{2} 271.1441$.

MP: $152-154^{\circ} \mathrm{C}$. 


\section{Peptide and Protein Irradiation Procedures}

\section{Analysis of crude-LC/MS traces}

Analysis of crude reactions by LC/MS was performed by integrating the area under the peak associated with peptide starting material, conjugate, and any oxidation or decomposition peaks. These values were totaled, and estimated percentages were assigned according to relative intensities of peaks. A sample is shown below for 1 of the 2 experiments that comprise the data point in Table 1, Entry 3.

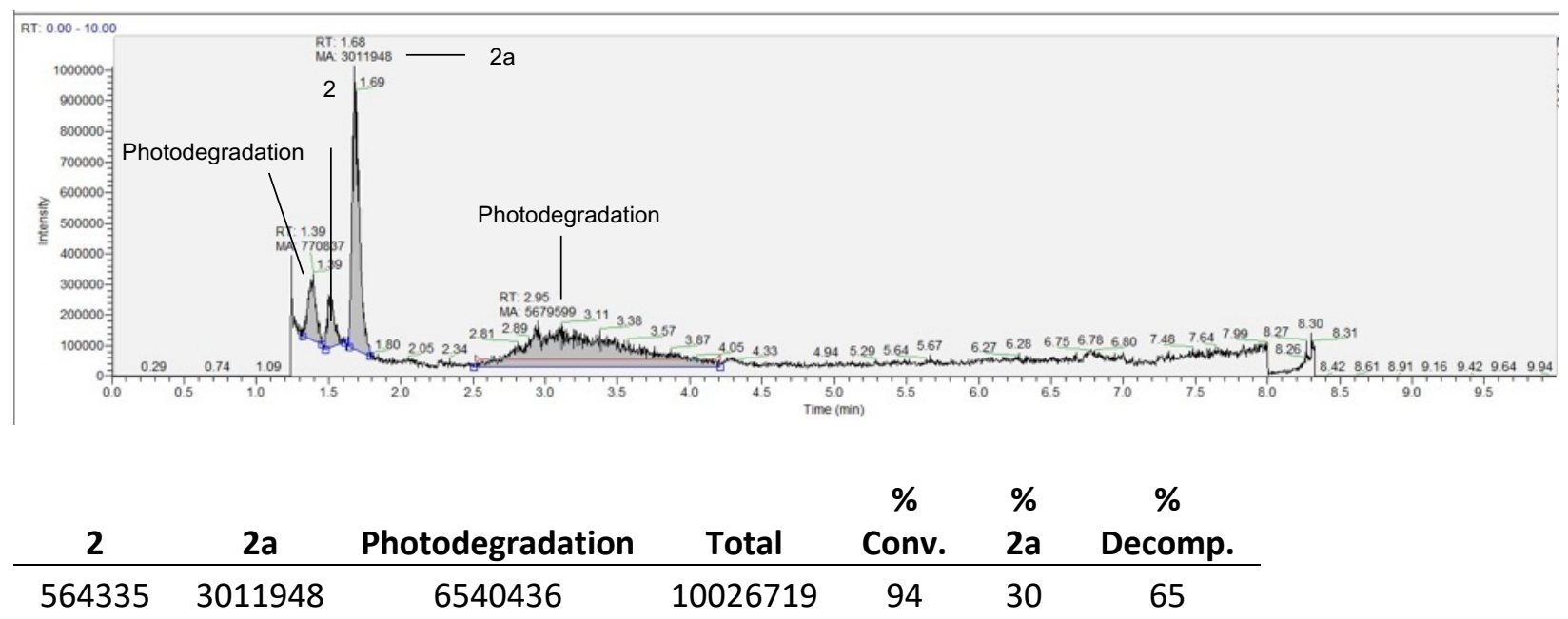

\section{General Procedure B: Photochemical irradiation of peptides \& proteins*}<smiles>BrCCc1c[nH]c2ccccc12</smiles><smiles>[R]OC(=O)N(C)[n+]1c(C)cc([R])cc1CCCCCCc1c[nH]c2cc([N+](C)C)ccc12</smiles>

To a $2 \mathrm{~mL}$ Pyrex LC/MS vial (Thermo model \# 03-391-39) with a solution containing the desired peptide were sequentially added solutions of glutathione, pyridinium salt, and ammonium acetate. The resulting solution was diluted to a final volume of $300 \mu \mathrm{L}$ and then degassed using Ar for a minimum of 20 minutes prior to irradiation. The actively sparging solution was then irradiated using a $302 \mathrm{~nm}$ UV lamp (Analytikjena, UVP 3UV Lamp, $8 \mathrm{~W}$ ), placed at a distance of $2 \mathrm{~mm}$ from the vial for the given time. The reaction mixture was then analyzed directly via LC/MS. 


\section{General procedure C: Labeling of Octreotide with pyridinium salt 1a using long-pass}

filters

To a $2 \mathrm{~mL}$ Pyrex LC/MS vial (Thermo model \# 03-391-39) with a solution containing the desired biomolecule were added solutions of pyridinium salt, glutathione, ammonium acetate. The resulting solution was diluted to a final volume of $300 \mu \mathrm{L}$ and then degassed using $\mathrm{Ar}$ for a minimum of 20 minutes prior to irradiation. The actively sparging solution was then irradiated using a $302 \mathrm{~nm}$ UV lamp (Analytikjena, UVP 3UV Lamp, $8 \mathrm{~W}$ ), fit with a $305 \mathrm{~nm}$ (Edmund Optics, R5000413228-17993) or a 320 nm (Edmund Optics, 4500187652-00-18078) long-pass filter, for the given time. The reaction mixture was directly analyzed via LC/MS.

\section{* Photochemistry Reactions Considerations/Troubleshooting}

To avoid oxidation of the peptide, the sparging with $\mathrm{N}_{2}$ or Ar must be continuous throughout both the 20-minute minimum sparge time as well as the reaction time. Lack of continuous sparging or inadequate sparging will lead to oxidation.

Stock solutions containing oxygen or moisture sensitive reagents such as glutathione should be prepared daily.

Verify concentrations of peptides via UV-Vis prior to reactions. With peptide acetate salts, the concentration by mass will often be incorrect.

Expunge all solutions before taking designated amount for reactions for consistent concentrations. 
(A)

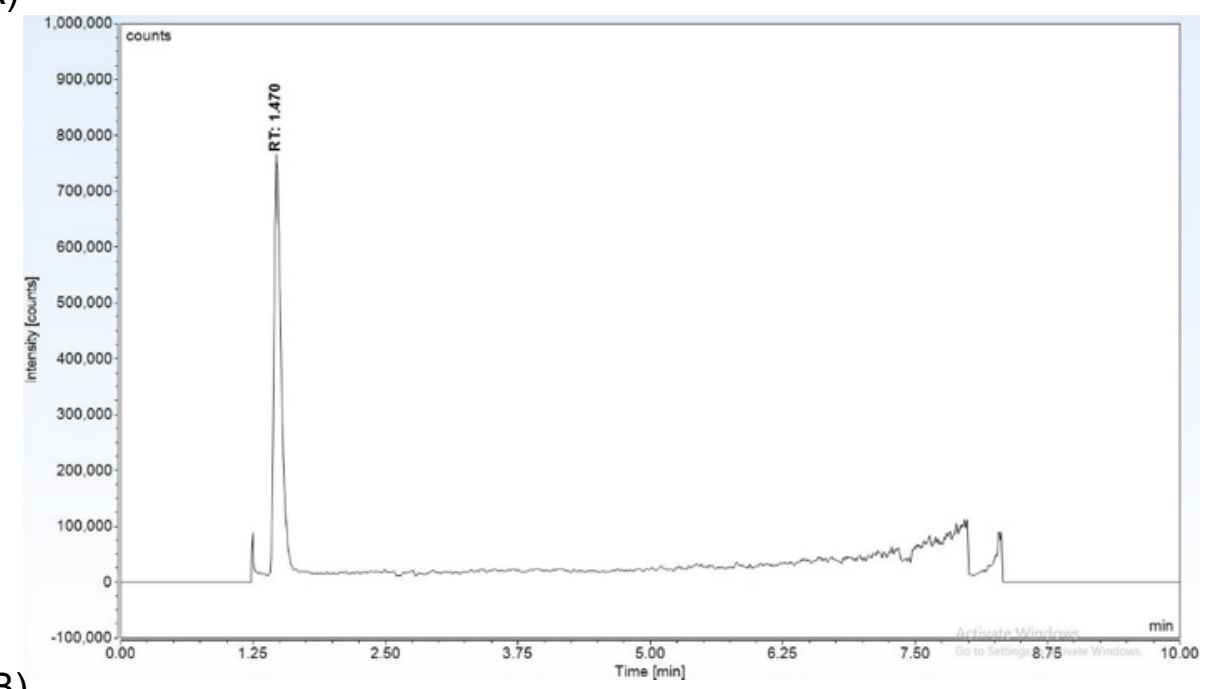

(B)

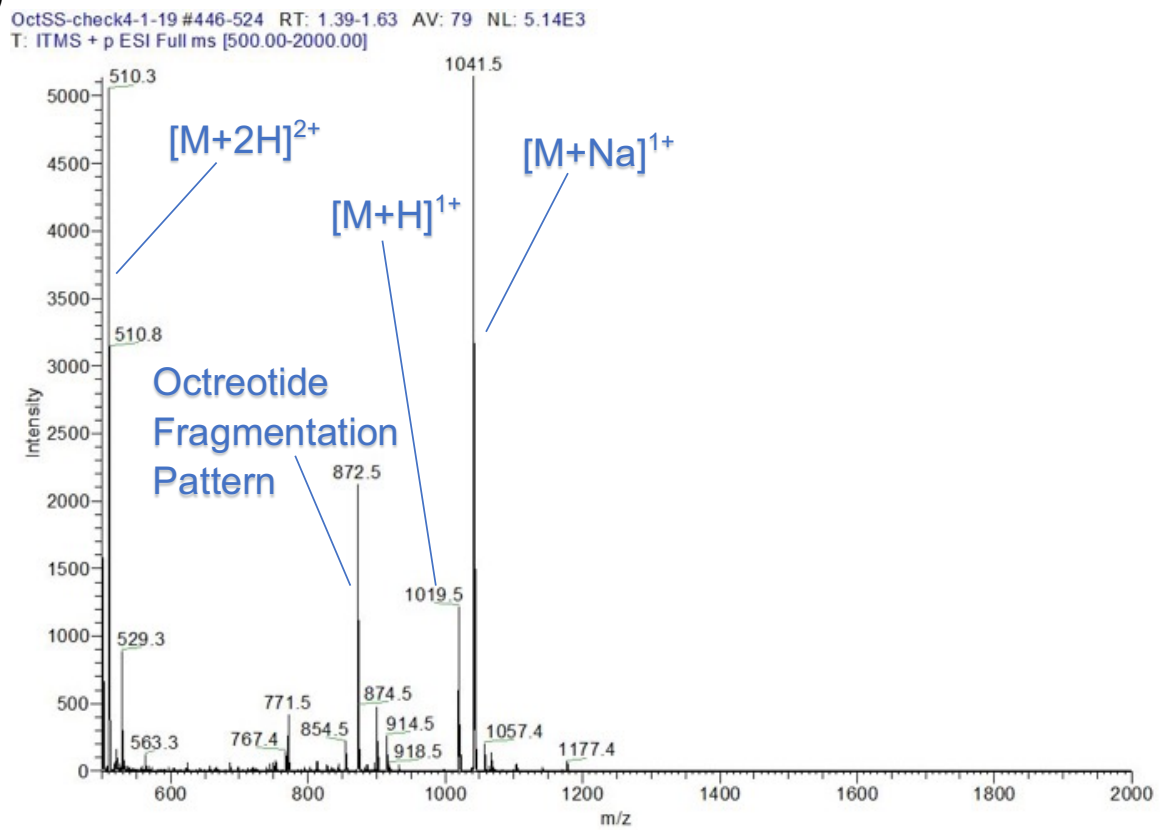

Figure 1. (A) LC/MS trace of 2 using method $B$. (B) Mass spectrum of $2\left(T_{r}=1.39-1.63 \mathrm{~min}\right)$. 


\section{Labelling of Octreotide with pyridinium salt 1a}

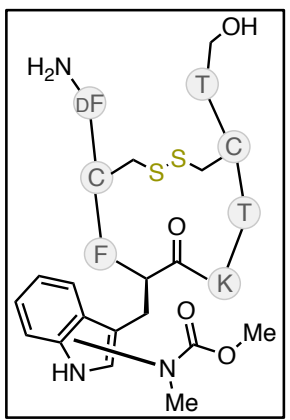

Labeling of octreotide with salt $1 \mathrm{a}$ was performed by following general procedure $\mathrm{B}$ using octreotide acetate $2\left(3 \mu \mathrm{L}, 10.7 \mathrm{mM}\right.$ solution in $\mathrm{H}_{2} \mathrm{O}, 100 \mu \mathrm{M}$ final concentration), $1 \mathrm{a}\left(21 \mu \mathrm{L}, 100 \mathrm{mM}\right.$ in $\mathrm{H}_{2} \mathrm{O}, 7 \mathrm{mM}$ final concentration), $\mathrm{NH}_{4} \mathrm{OAc}\left(3 \mu \mathrm{L}, 2 \mathrm{M}\right.$ in $\mathrm{H}_{2} \mathrm{O}, \mathrm{pH} 6.9,20 \mathrm{mM}$ final concentration), glutathione (3 $\mu \mathrm{L}, 100 \mathrm{mM}$ in $\mathrm{H}_{2} \mathrm{O}, 1 \mathrm{mM}$ final concentration) and water $(270 \mu \mathrm{L})$ with a 30 minute irradiation time. The reaction mixture was directly analyzed via LC/MS using method $B$ and was judged to have proceeded in $>95 \%$ conversion with a $>20: 1$ mono:di labelled ratio.

A similar reaction using $2\left(3 \mu \mathrm{L}, 10.7 \mathrm{mM}\right.$ solution in $\mathrm{H}_{2} \mathrm{O}, 100 \mu \mathrm{M}$ final concentration), $1 \mathrm{a}\left(21 \mu \mathrm{L}, 100 \mathrm{mM}\right.$ in $\mathrm{H}_{2} \mathrm{O}, 7 \mathrm{mM}$ final concentration), $\mathrm{NH}_{4} \mathrm{OAc}$

(3 $\mu \mathrm{L}, 2 \mathrm{M}$ in $\mathrm{H}_{2} \mathrm{O}, \mathrm{pH} 6.9,20 \mathrm{mM}$ final concentration), glutathione $\left(3 \mu \mathrm{L}, 100 \mathrm{mM}\right.$ in $\mathrm{H}_{2} \mathrm{O}, 1 \mathrm{mM}$ final concentration) and water $(270 \mu \mathrm{L})$ proceeded in $>95 \%$ conversion with a $>20: 1$ : mono:di labelled ratio.

(A)

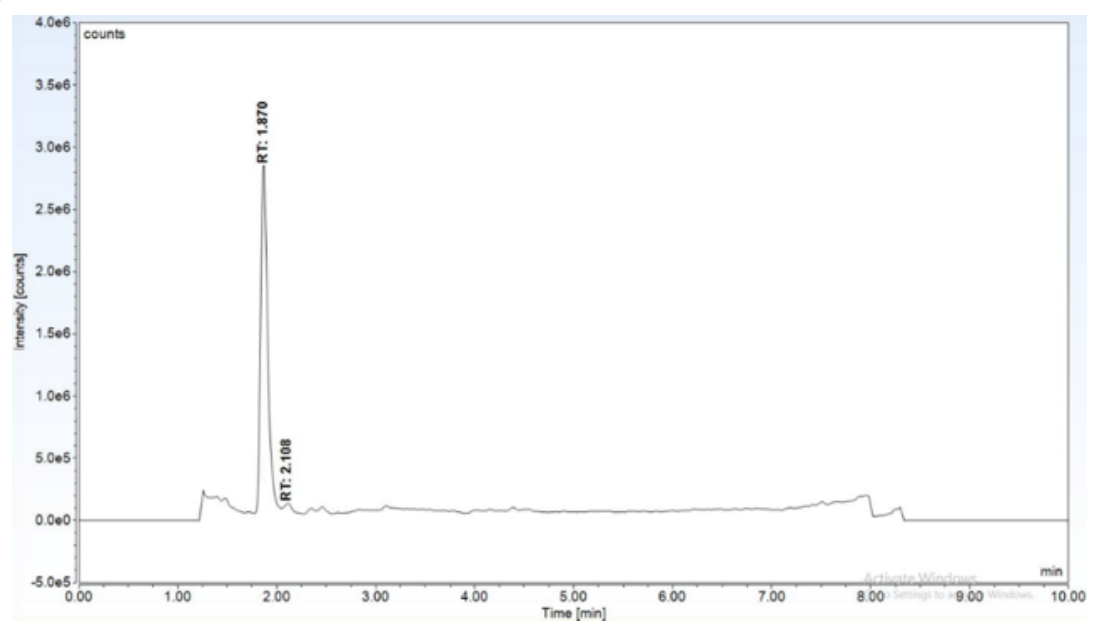

(B)

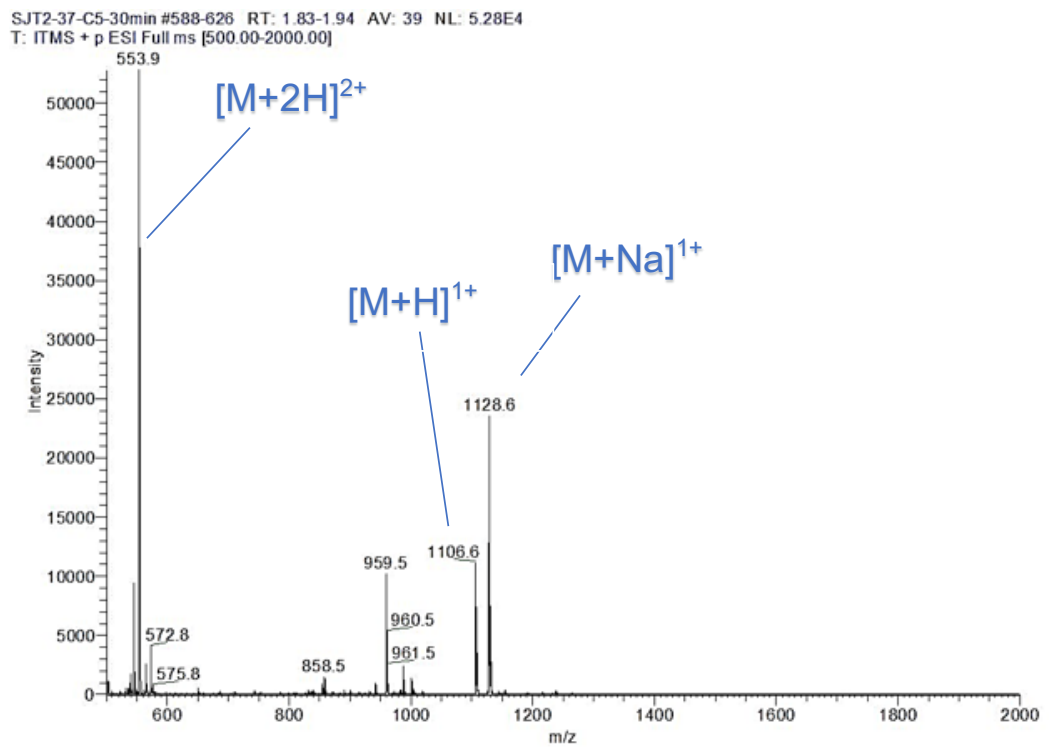

Figure 2. (A) LC/MS trace of crude reaction mixture between 2 and salt 1a. (B) Mass spectrum of conjugate $2 \mathrm{a}\left(\mathrm{T}_{\mathrm{r}}=1.83-1.94 \mathrm{~min}\right)$. 


\section{Labeling of Octreotide with pyridinium salt 1a at low concentration}

Labeling of octreotide with salt 1a was performed by following general procedure $\mathrm{B}$ using 2 (10 $\mu \mathrm{L}, 240 \mu \mathrm{M}, 10 \mu \mathrm{M}$ final concentration), $1 \mathrm{a}\left(84 \mu \mathrm{L}, 25 \mathrm{mM}, 7 \mathrm{mM}\right.$ final concentration), $\mathrm{NH}_{4} \mathrm{OAc}$ $(60 \mu \mathrm{L}, 100 \mathrm{M}, \mathrm{pH} 6.9,20 \mathrm{mM}$ final concentration), glutathione $(60 \mu \mathrm{L}, 5 \mathrm{mM}, 1 \mathrm{mM}$ final concentration), and water $(86 \mu \mathrm{L})$ with a 30 minute irradiation time. The reaction mixture was directly analyzed via LC/MS using method B and was judged to have proceeded in $>95 \%$ conversion with a $>20: 1$ mono:di labelled ratio.

A replicate reaction using $2(10 \mu \mathrm{L}, 240 \mu \mathrm{M}, 10 \mu \mathrm{M}$ final concentration), 1a (84 $\mu \mathrm{L}, 25 \mathrm{mM}, 7 \mathrm{mM}$ final concentration), $\mathrm{NH}_{4} \mathrm{OAc}(60 \mu \mathrm{L}, 100 \mathrm{mM}, \mathrm{pH} 6.9,20 \mathrm{mM}$ final concentration), glutathione (60 $\mu \mathrm{L}, 5 \mathrm{mM}, 1 \mathrm{mM}$ final concentration) and water $(86 \mu \mathrm{L})$ proceeded in $>95 \%$ conversion, $>20: 1$ mono:di labelled ratio.

(A)

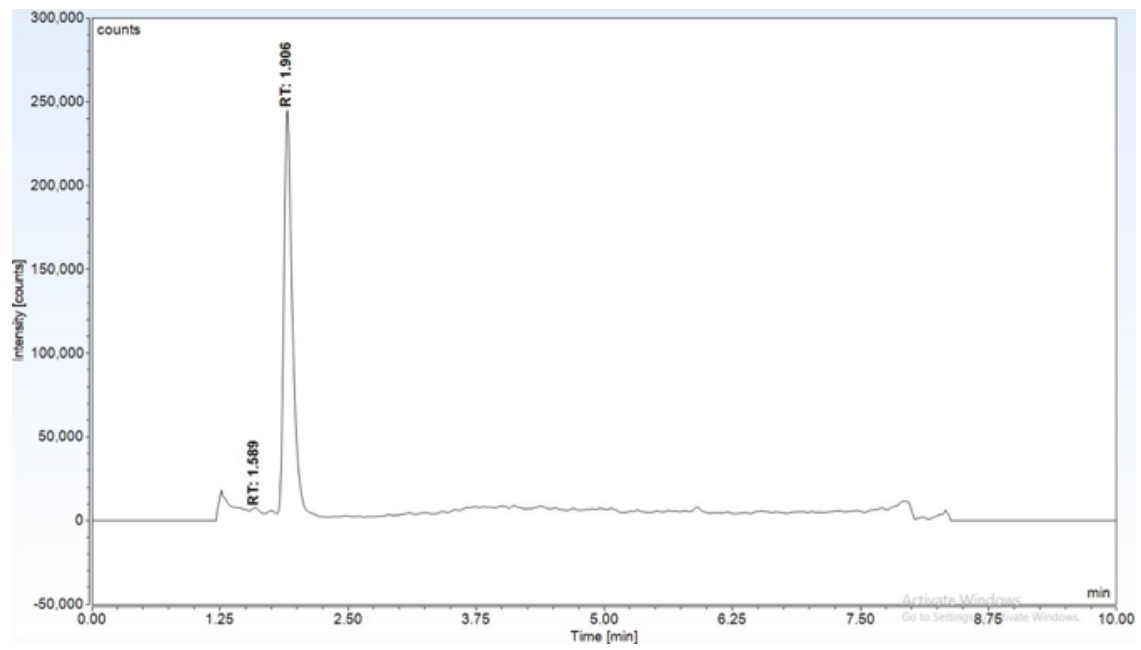

(B)

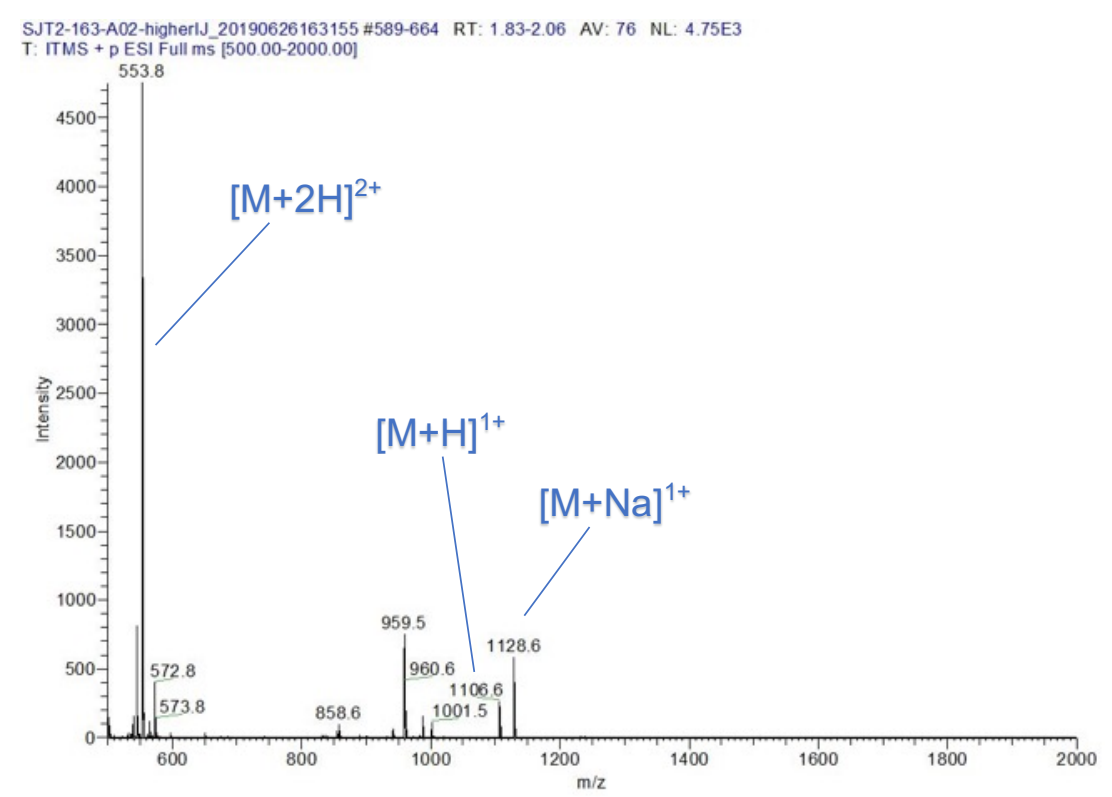

Figure 3. (A) LC/MS of crude reaction between 2 and salt 1a. (B) Mass spectrum of conjugate 2a $\left(\mathrm{T}_{\mathrm{r}}=1.83-2.06 \mathrm{~min}\right)$. 


\section{Preparative Scale Labeling of Octreotide (2) with 1a}

Preparative scale labeling of Octreotide with salt 1 a was performed using the following procedure: to a $10 \mathrm{~mL}$ pear-shaped flask equipped with a stir-bar and fitted with a Chemglass air-free Schlenk adapter (item number AF-0501-01) were sequentially added salt 1a (29.6 mg, 100 mmols, $20 \mathrm{mM}$ final concentration), LC/MS grade water ( $3.3 \mathrm{~mL}), 2(700 \mu \mathrm{L}, 5 \mathrm{mM}, 700 \mu \mathrm{M}$ final concentration), $\mathrm{NH}_{4} \mathrm{OAc}\left(500 \mu \mathrm{L}, 200 \mathrm{mM}\right.$ in $\mathrm{H}_{2} \mathrm{O}, \mathrm{pH}$ 6.9, $20 \mathrm{mM}$ final concentration), and glutathione ( $500 \mu \mathrm{L}, 50 \mathrm{mM}, 5 \mathrm{mM}$ final concentration) to give a final volume of $5 \mathrm{~mL}$. The homogeneous solution was then degassed via iterative freeze, pump, thaw cycles before being placed $6 \mathrm{~cm}$ above a stir plate. A $302 \mathrm{~nm}$ UV lamp (Analytikjena, UVP 3UV Lamp, 8W) was positioned $2 \mathrm{~mm}$ away from the flask, at an angle parallel to the taper of the flask such that the solution was entirely in the path of the lamp. The solution was irradiated for the 3 hours while stirring at $800 \mathrm{rpm}$. The reaction mixture was analyzed directly via LC/MS where it was judged to have proceeded in $91 \%$ conversion corresponding to $82 \%$ monolabeled, and $2 \%$ dilabeled (>20:1 mono:di labeled ratio). The reaction mixture was then purified directly by HPLC using method A to obtain $\mathbf{2 a}$ ( $2.4 \mathrm{mg}, 71 \%$ yield). Two additional experiments were performed, using the same procedure, which resulted in $66 \%$ and $68 \%$ isolated yields for an average of $68 \%$. Yields were determined via NMR using $450 \mu \mathrm{M}$ DMF as an internal standard.

\section{(A)}

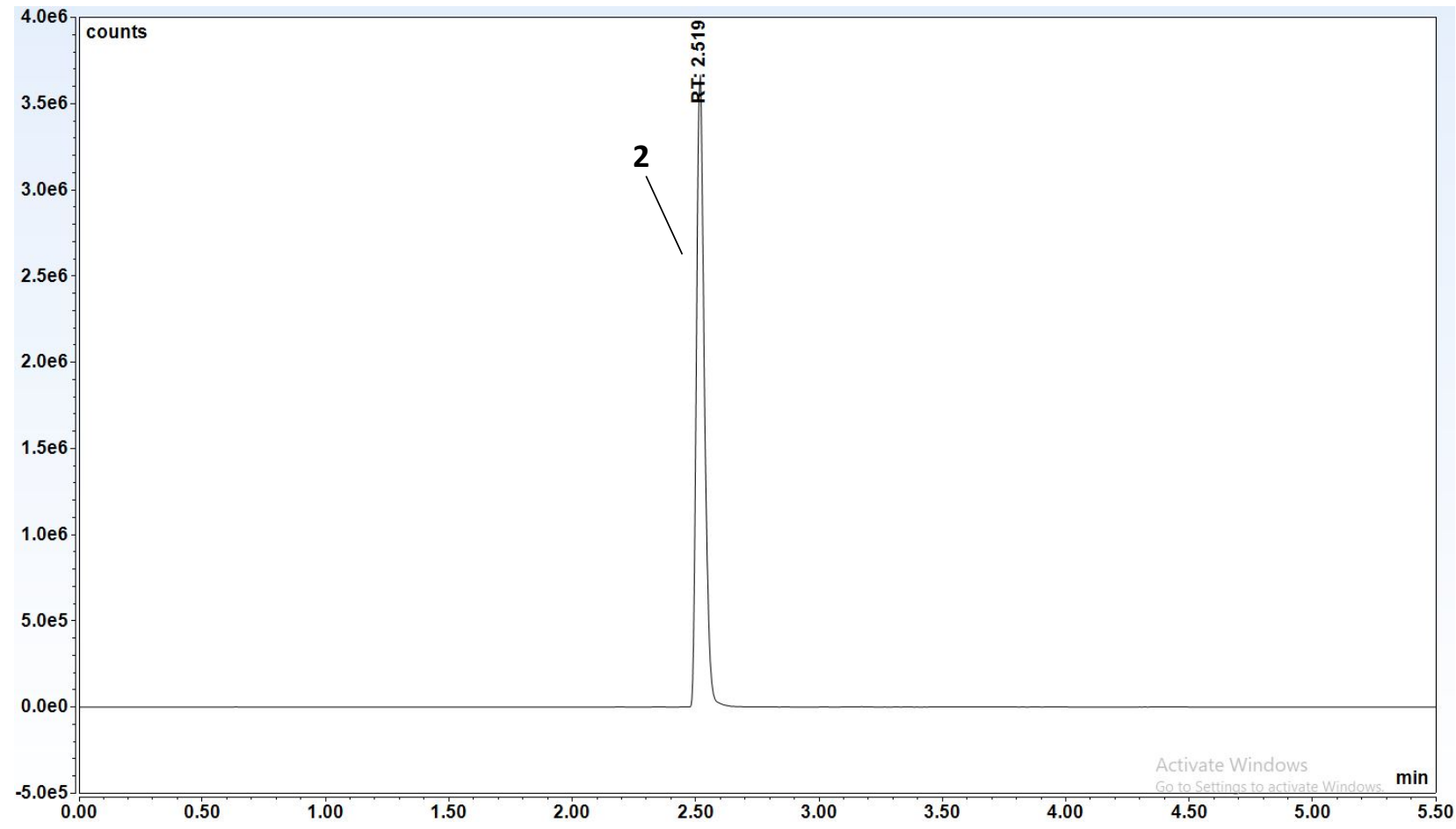


(B)

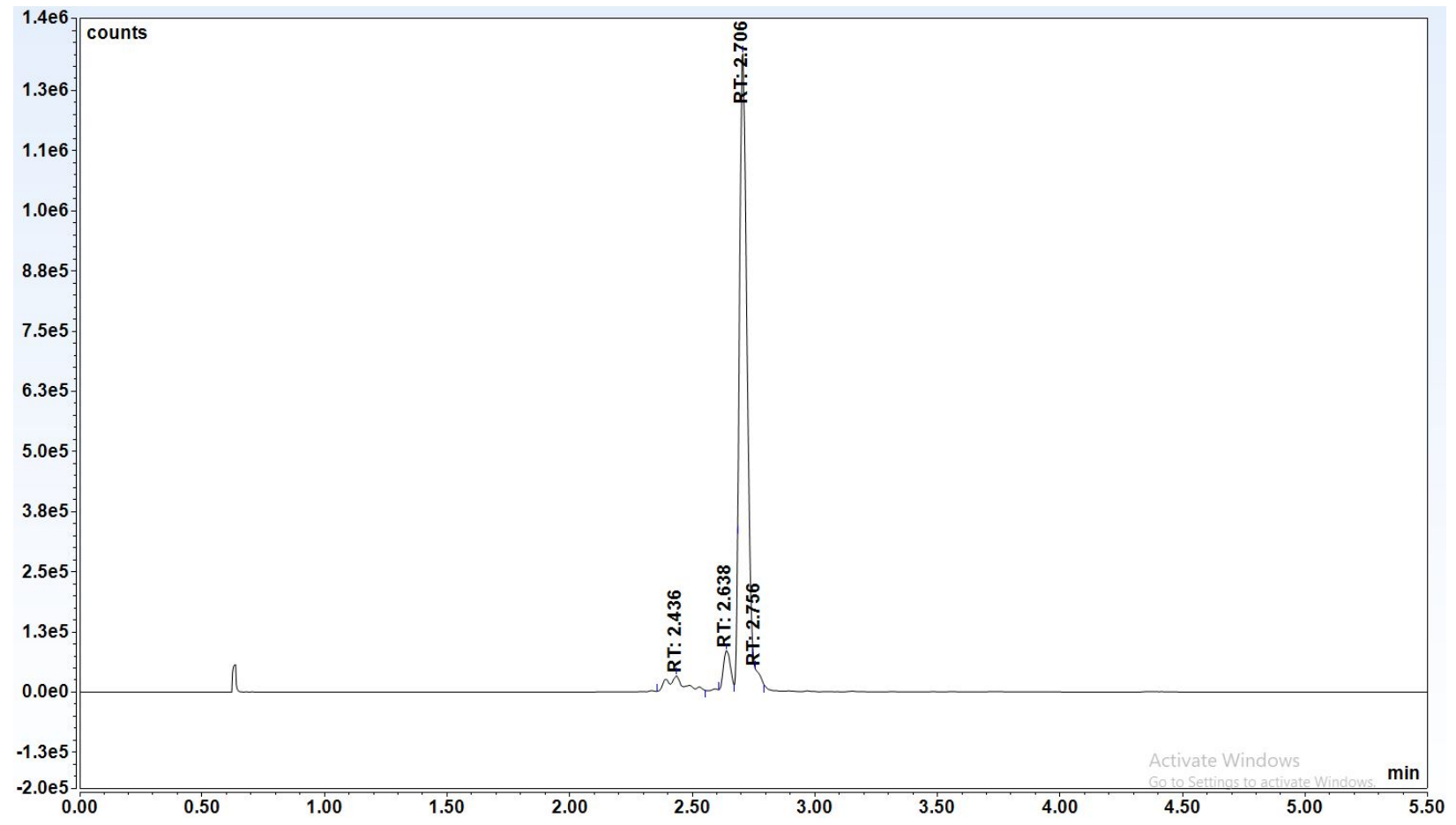

(C)

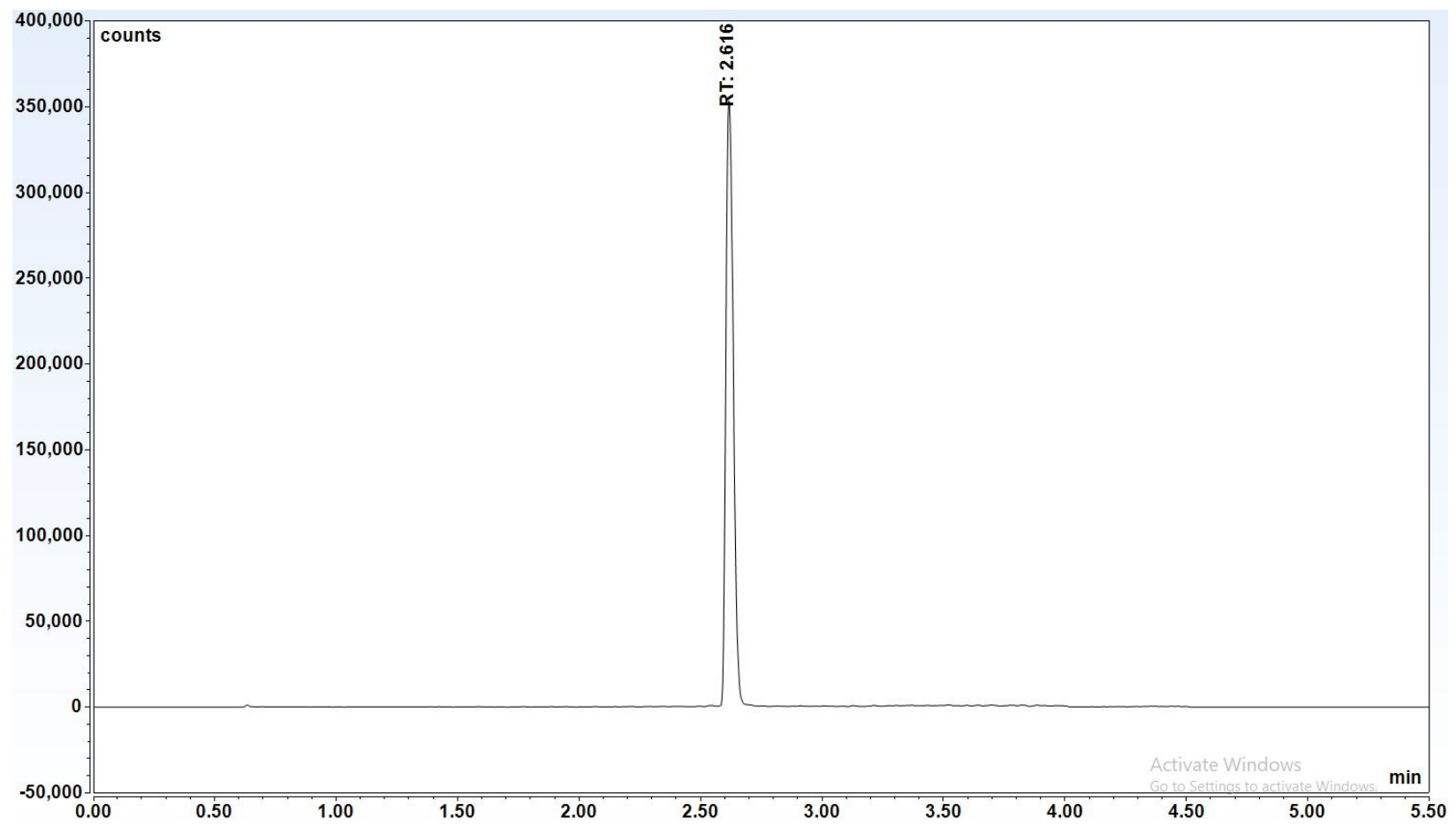


(D)

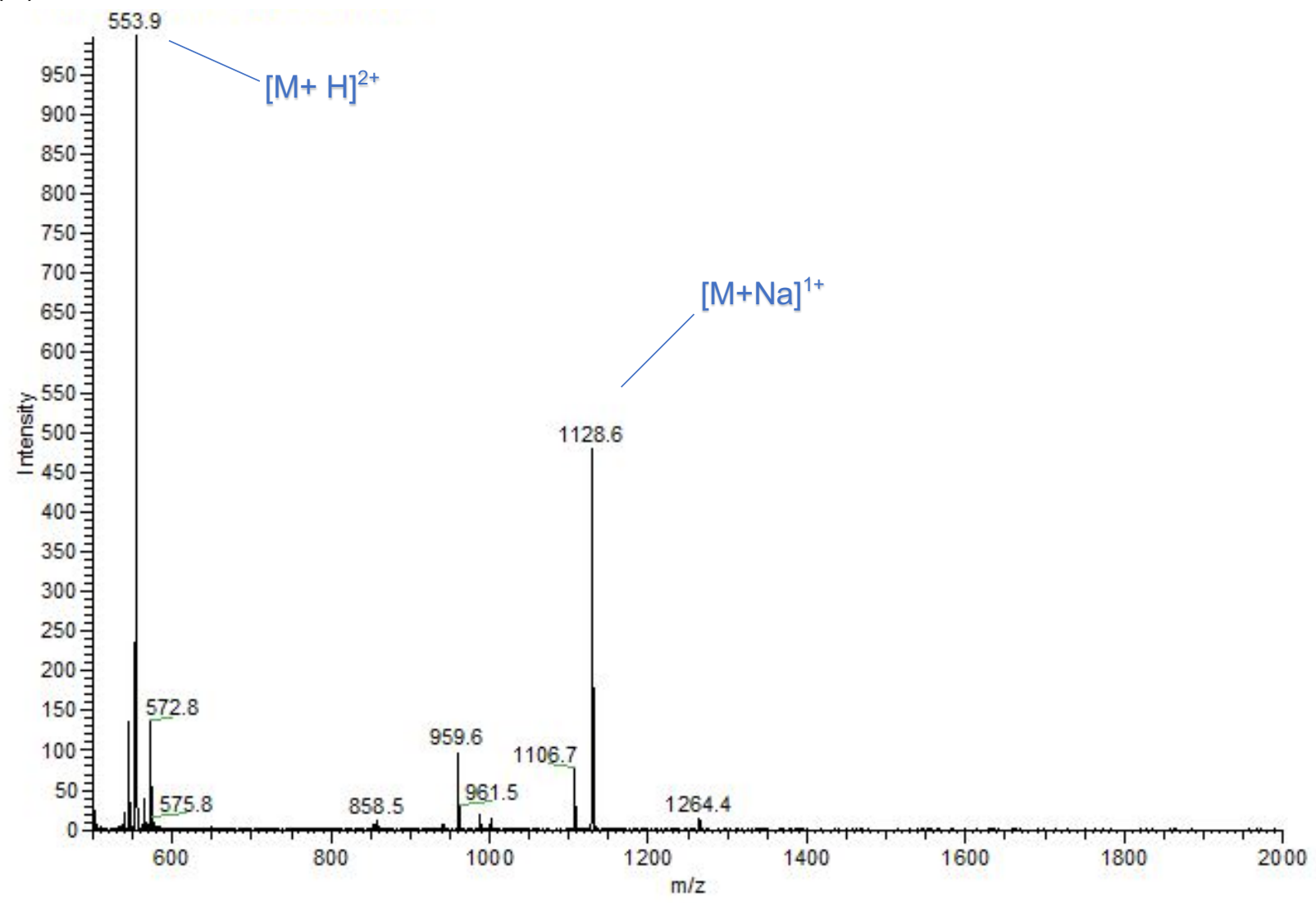

Figure 4. (A) LC/MS chromatogram stock solution of 2 using method $E$. (B) LC/MS of crude reaction mixture using method $E$. (C) LC/MS chromatogram of isolated $2 a$ using method $E$. (D) Mass spectrum of isolated conjugate $\mathbf{2 a}$. 


\section{Labeling of Octreotide with pyridinium salt S1}

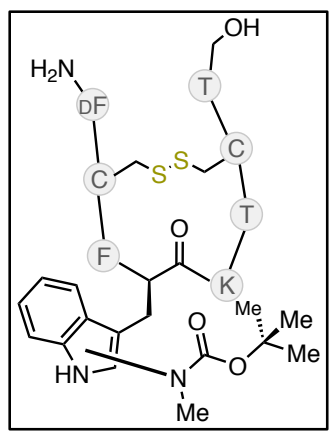

Labeling of octreotide with salt $\mathbf{S 1}$ was performed by following general procedure B using $2(34 \mu \mathrm{L}, 0.88 \mathrm{mM}, 100 \mu \mathrm{M}$ final concentration), S1 (30 $\mu \mathrm{L}, 70 \mathrm{mM}, 7 \mathrm{mM}$ final concentration), $\mathrm{NH}_{4} \mathrm{OAc}(3 \mu \mathrm{L}, 2 \mathrm{M}, \mathrm{pH} 6.9,20 \mathrm{mM}$ final concentration), glutathione $(3 \mu \mathrm{L}, 100 \mathrm{mM}, 1 \mathrm{mM}$ final concentration) and water $(230 \mu \mathrm{L})$ with a 60 minute irradiation time. The reaction mixture was directly analyzed via LC/MS using method $B$ and was judged to have proceeded in $>95 \%$ conversion with a $>20: 1$ mono:di labelled ratio.

A replicate reaction using $2(34 \mu \mathrm{L}, 0.88 \mathrm{mM}, 100 \mu \mathrm{M}$ final concentration), S1 (30 $\mu \mathrm{L}, 70 \mathrm{mM}, 7 \mathrm{mM}$ final concentration), $\mathrm{NH}_{4} \mathrm{OAc}(3 \mu \mathrm{L}, 2 \mathrm{M}, \mathrm{pH} 6.9$, $20 \mathrm{mM}$ final concentration), glutathione $(3 \mu \mathrm{L}, 100 \mathrm{mM}, 1 \mathrm{mM}$ final concentration) and water $(230 \mu \mathrm{L})$ proceeded in $>95 \%$ conversion, $>20: 1$ mono:di labelled ratio.

(A)

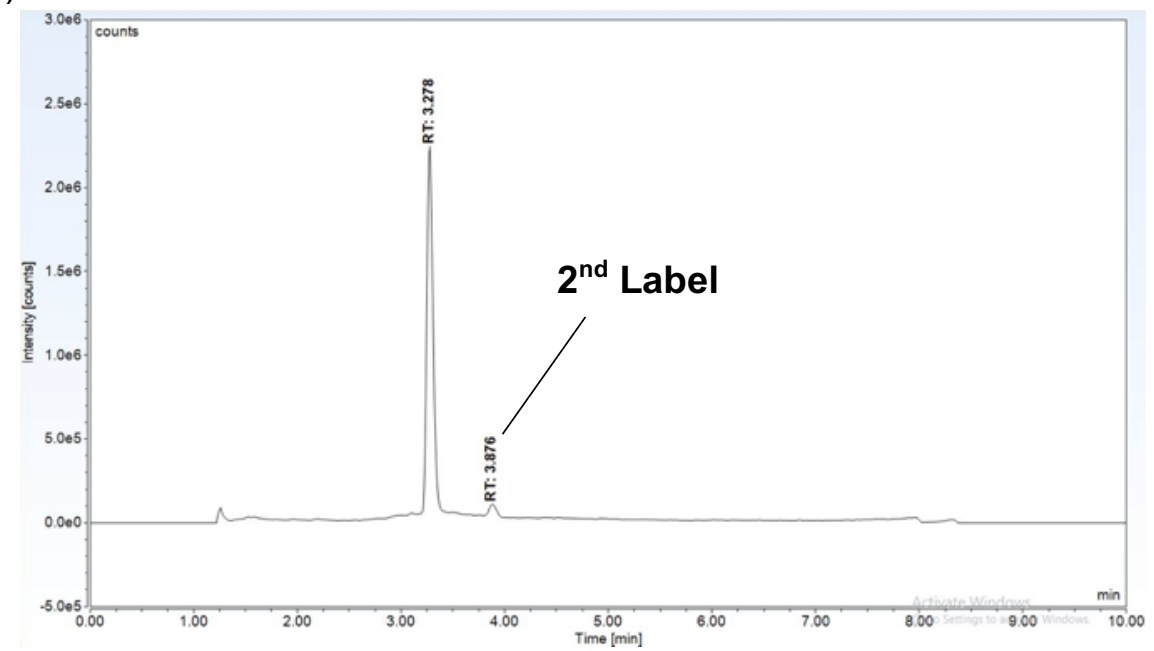

(B)

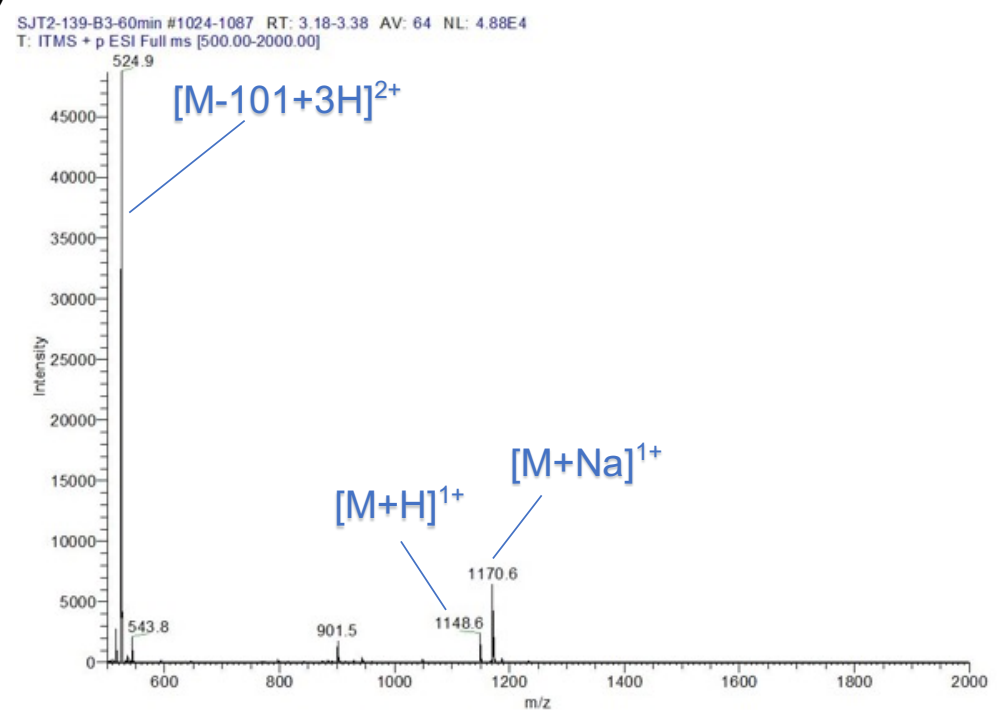

Figure 5. (A) LC/MS of crude reaction between 2 and salt S1. (B) Mass spectrum of conjugate $2 \mathbf{b}\left(\mathrm{T}_{\mathrm{r}}=3.18-3.38 \mathrm{~min}\right)$. 


\section{Labeling of Octreotide with pyridinium salt S3}

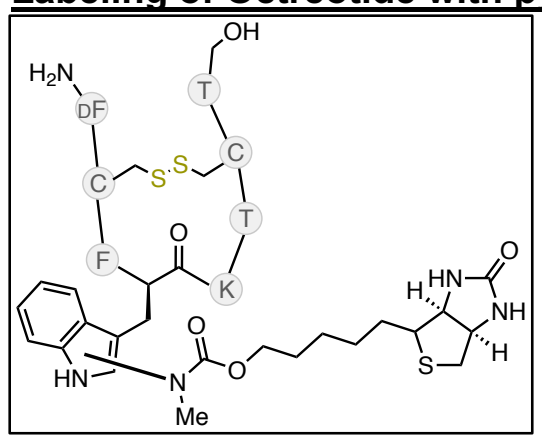

Labeling of octreotide with salt $\mathbf{S 3}$ was performed by following general procedure $\mathrm{B}$ using $2\left(25 \mu \mathrm{L}, 1.2 \mathrm{mM}\right.$ in $20 \mathrm{mM} \mathrm{NH}_{4} \mathrm{OAc}$, $100 \mu \mathrm{M}$ final concentration), S3 $(3 \mu \mathrm{L}, 100 \mathrm{mM}$ in $20 \mathrm{mM}$ $\mathrm{NH}_{4} \mathrm{OAc}, 1 \mathrm{mM}$ final concentration), glutathione $(3 \mu \mathrm{L}, 100 \mathrm{mM}$ in $20 \mathrm{mM} \mathrm{NH}_{4} \mathrm{OAc}, 1 \mathrm{mM}$ final concentration) and $\mathrm{NH}_{4} \mathrm{OAc}(269$ $\mu \mathrm{L}, 20 \mathrm{mM}, \mathrm{pH} 6.9,20 \mathrm{mM}$ final concentration) with a 60 minute irradiation time. The reaction mixture was directly analyzed via LC/MS using method $B$ and was judged to have proceeded in $95 \%$ conversion with a 13:1 mono:di labelled ratio.

A replicate reaction using $2\left(23 \mu \mathrm{L}, 1.3 \mathrm{mM}\right.$ in $20 \mathrm{mM} \mathrm{NH}_{4} \mathrm{OAc}, 100 \mu \mathrm{M}$ final concentration), S3 (3 $\mu \mathrm{L}, 100 \mathrm{mM}$ in $20 \mathrm{mM} \mathrm{NH}_{4} \mathrm{OAc}, 1 \mathrm{mM}$ final concentration), glutathione ( $3 \mu \mathrm{L}, 100 \mathrm{mM}$ in 20 $\mathrm{mM} \mathrm{NH}{ }_{4} \mathrm{OAc}, 1 \mathrm{mM}$ final concentration) and $\mathrm{NH}_{4} \mathrm{OAc}(271 \mu \mathrm{L}, 20 \mathrm{mM}, \mathrm{pH} 6.9,20 \mathrm{mM}$ final concentration) proceeded in 94\% conversion, 15:1 mono:di labelled ratio. 
(A)

(B)

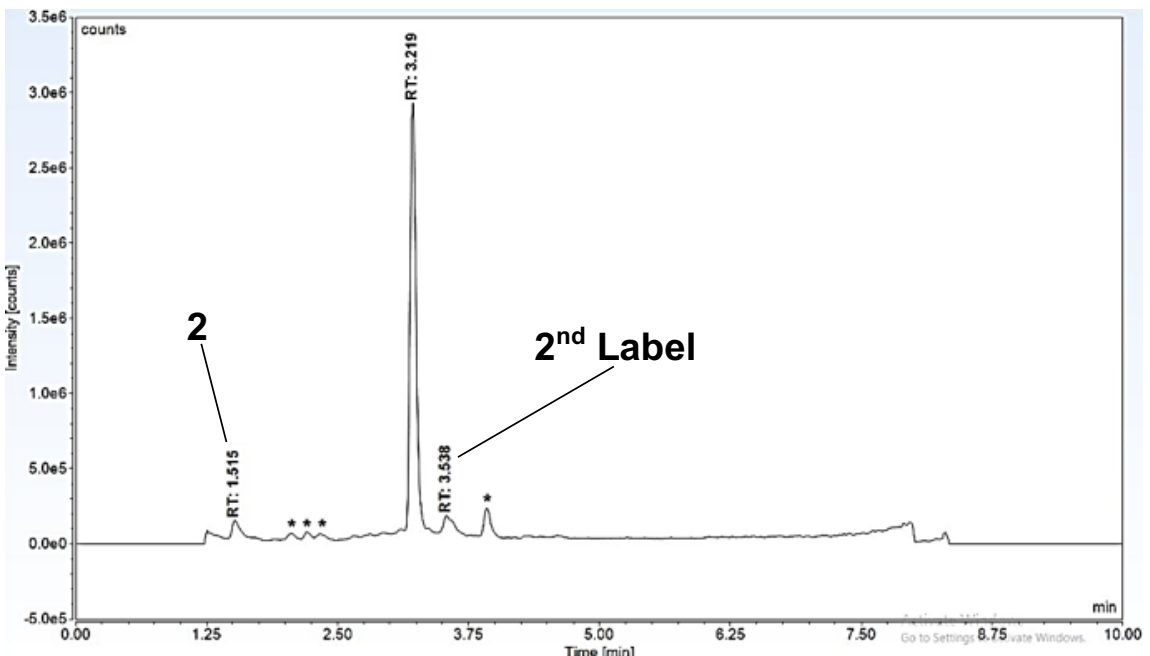

)

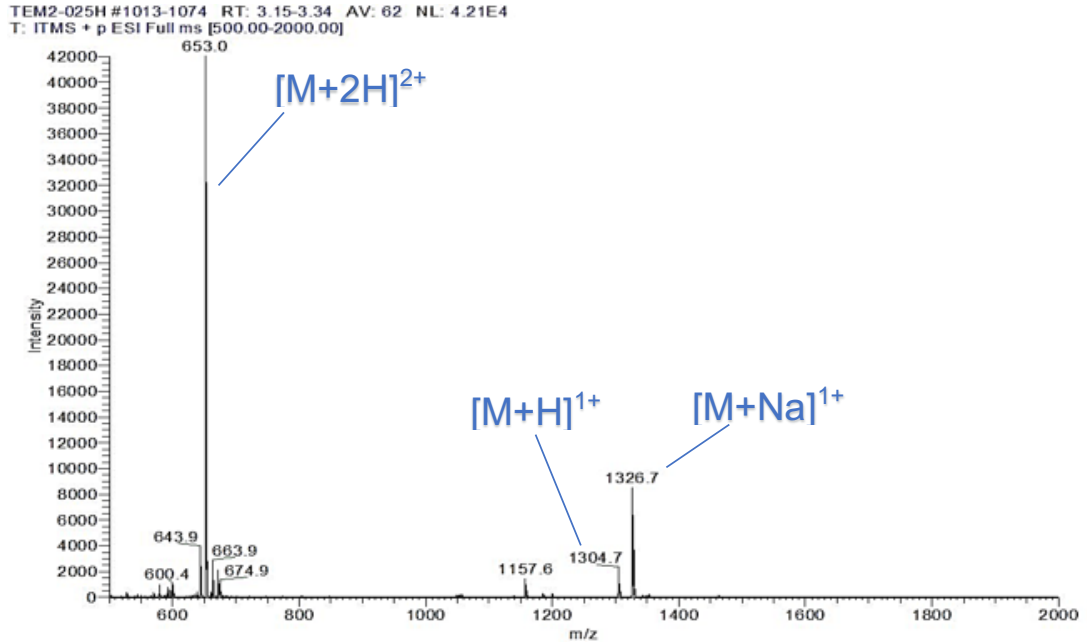

(C)

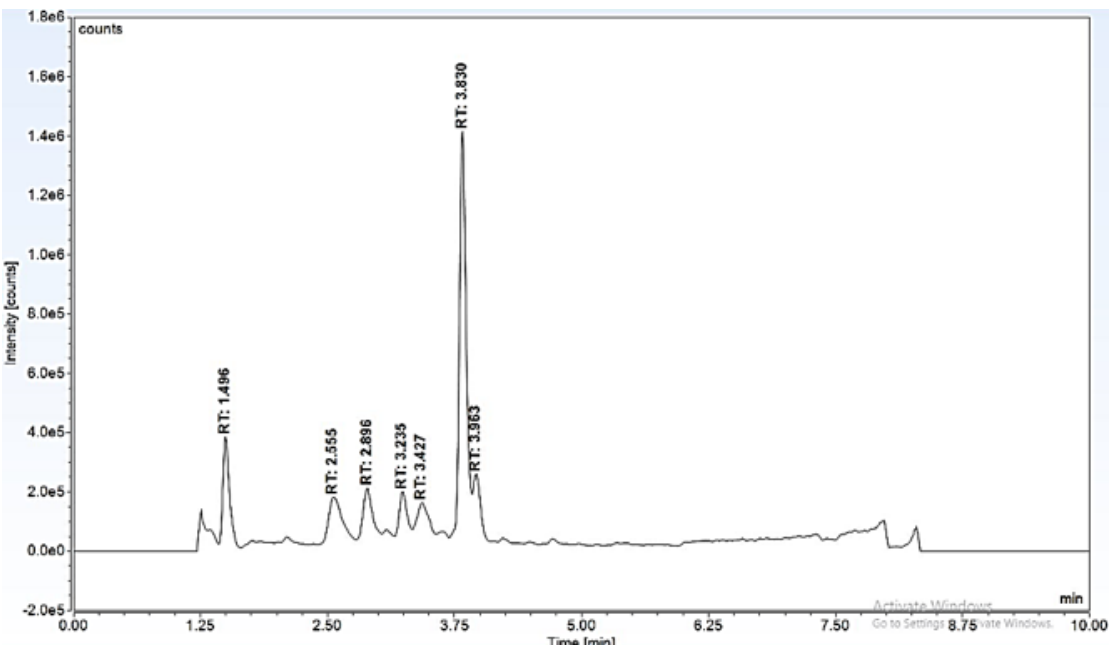

Figure 6. (A) LC/MS of crude reaction between 2 and salt S3. *=byproducts from S3 (B) Mass spectrum of conjugate $2 \mathrm{c}\left(\mathrm{T}_{\mathrm{r}}=3.15-3.34 \mathrm{~min}\right)$. (C) $\mathrm{LC} / \mathrm{MS}$ trace of irradiated $2 \mathrm{c}$. 


\section{Labeling of Octreotide with pyridinium salt $1 \mathrm{~b}$}

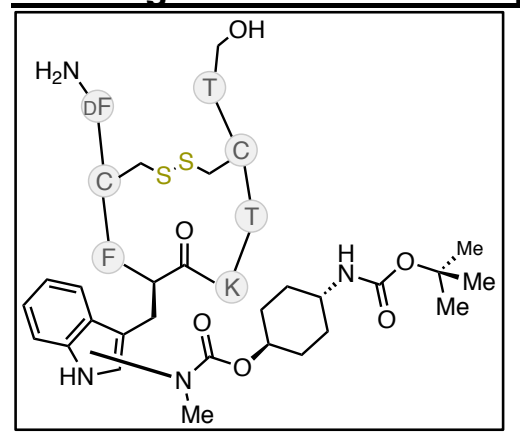

Labeling of octreotide with salt $\mathbf{1 b}$ was performed by following general procedure B with $2\left(23 \mu \mathrm{L}, 1.3 \mathrm{mM}\right.$ in $20 \mathrm{mM} \mathrm{NH}{ }_{4} \mathrm{OAc}$, $100 \mu \mathrm{M}$ final concentration), $1 \mathbf{b}\left(9 \mu \mathrm{L}, 35 \mathrm{mM}\right.$ in $20 \mathrm{mM} \mathrm{NH}_{4} \mathrm{OAc}$, $1 \mathrm{mM}$ final concentration), glutathione $(3 \mu \mathrm{L}, 100 \mathrm{mM}$ in $20 \mathrm{mM}$ $\mathrm{NH}_{4} \mathrm{OAc}, 1 \mathrm{mM}$ final concentration) and $\mathrm{NH}_{4} \mathrm{OAc}(265 \mu \mathrm{L}, 20 \mathrm{mM}$ $\mathrm{pH} 6.9,20 \mathrm{mM}$ final concentration) with a 60 minute irradiation time. The reaction mixture was directly analyzed via LC/MS using method $B$ and was judged to have proceeded in $>95 \%$ conversion with a ration of $>20: 1$ mono:di labelled ratio.

A replicate reaction with $2\left(25 \mu \mathrm{L}, 1.2 \mathrm{mM}\right.$ in $20 \mathrm{mM} \mathrm{NH}_{4} \mathrm{OAc}, 100 \mu \mathrm{M}$ final concentration), 1 b (9 $\mu \mathrm{L}, 35 \mathrm{mM}$ in $20 \mathrm{mM} \mathrm{NH}_{4} \mathrm{OAc}, 1 \mathrm{mM}$ final concentration), glutathione (3 $\mu \mathrm{L}, 100 \mathrm{mM}$ in $20 \mathrm{mM}$ $\mathrm{NH}_{4} \mathrm{OAc}, 1 \mathrm{mM}$ final concentration) and $\mathrm{NH}_{4} \mathrm{OAc}(263 \mu \mathrm{L}, 20 \mathrm{mM}, \mathrm{pH} 6.9,20 \mathrm{mM}$ final concentration) proceeded in $>95 \%$ conversion with a ration of $>20: 1$ mono:di labelled ratio. 
(A)

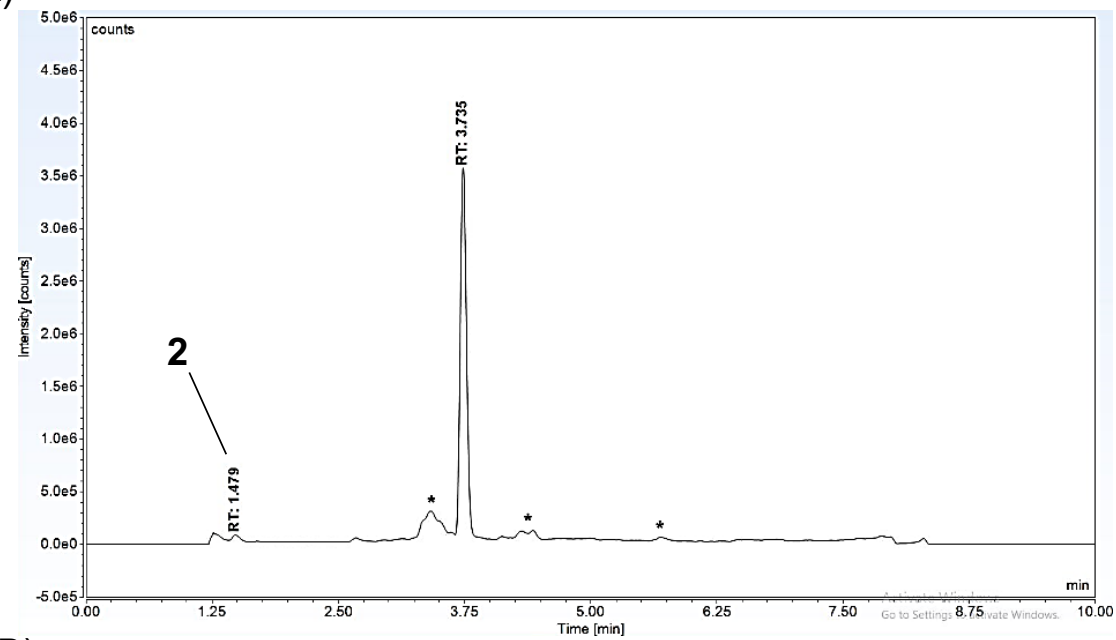

(B)

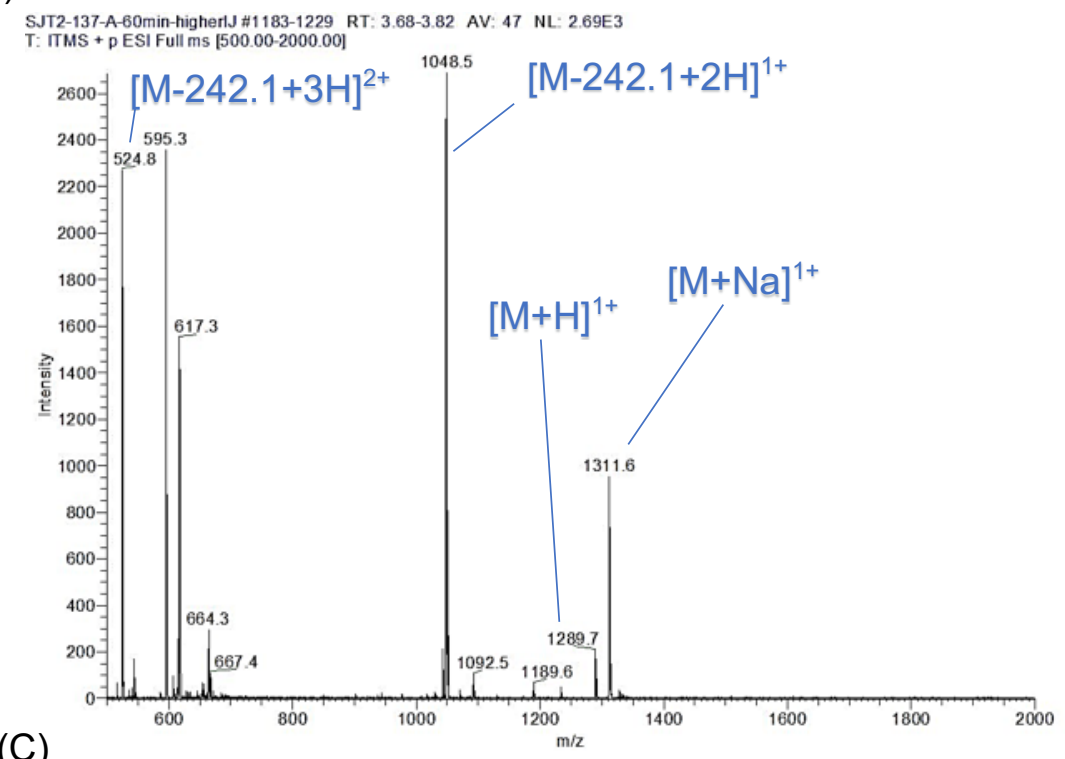

(C)

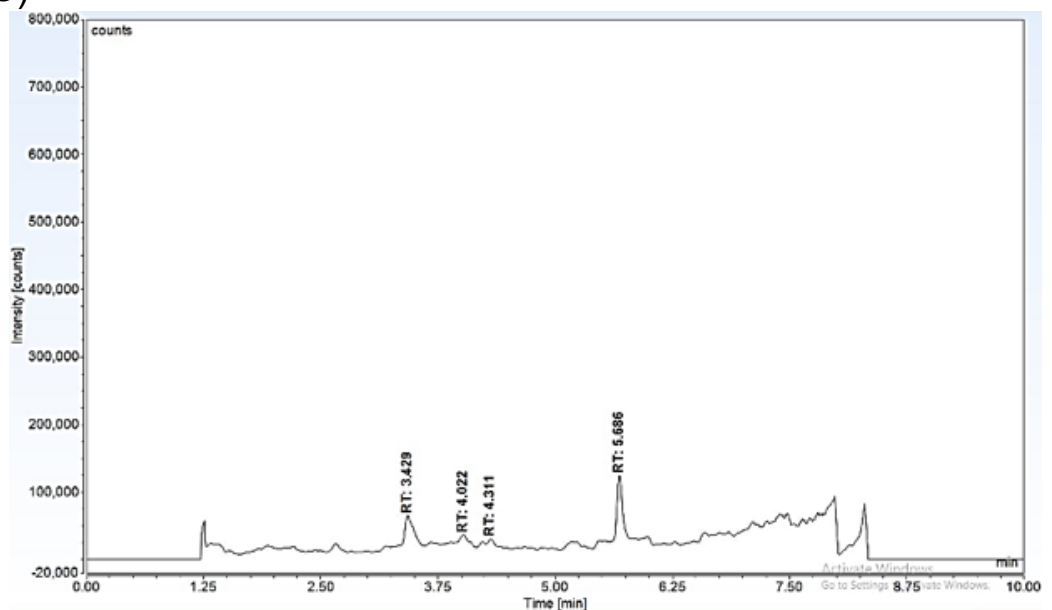

Figure 7. (A) LC/MS of crude reaction between 2 and salt $\mathbf{1 b} .{ }^{*}=$ byproducts from $\mathbf{1 b}$ (B) Mass spectrum of conjugate $\mathbf{2} \mathbf{d}\left(T_{r}=3.68-3.82 \mathrm{~min}\right)$. (C) $L C / M S$ trace of irradiated $\mathbf{2 d}$. 


\section{Labeling of Octreotide with pyridinium salt S5}

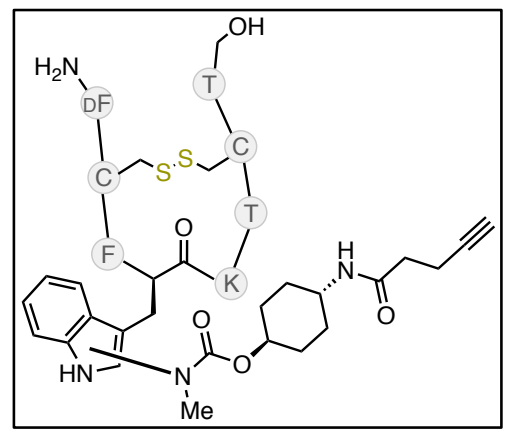

Labeling of octreotide with salt S5 was performed using $2(13 \mu \mathrm{L}$, $2.4 \mathrm{mM}, 100 \mu \mathrm{M}$ final concentration), S5 (30 $\mu \mathrm{L}, 10 \mathrm{mM}, 1 \mathrm{mM}$ final concentration), glutathione $(30 \mu \mathrm{L}, 10 \mathrm{mM}, 1 \mathrm{mM}$ final concentration), $\mathrm{NH}_{4} \mathrm{OAc}(60 \mu \mathrm{L}, 100 \mathrm{mM}, \mathrm{pH} 6.9,20 \mathrm{mM}$ final concentration) and water $(167 \mu \mathrm{L})$ with a 60 minute irradiation time. The reaction mixture was directly analyzed via LC/MS using method B and was judged to have proceeded in $94 \%$ label with a $>20: 1$ mono:di labelled ratio.

A replicate reaction using $2(13 \mu \mathrm{L}, 2.4 \mathrm{mM}, 100 \mu \mathrm{M}$ final concentration), S5 $(30 \mu \mathrm{L}, 10 \mathrm{mM}, 1 \mathrm{mM}$ final concentration), glutathione (30 $\mu \mathrm{L}, 10 \mathrm{mM}, 1 \mathrm{mM}$ final concentration), $\mathrm{NH}_{4} \mathrm{OAc}(60 \mu \mathrm{L}, 100 \mathrm{mM}, \mathrm{pH} 6.9,20 \mathrm{mM}$ final concentration) and water $(167 \mu \mathrm{L})$ proceeded in 95\% label, with a $>20: 1$ mono:di labelled ratio. 
(A)

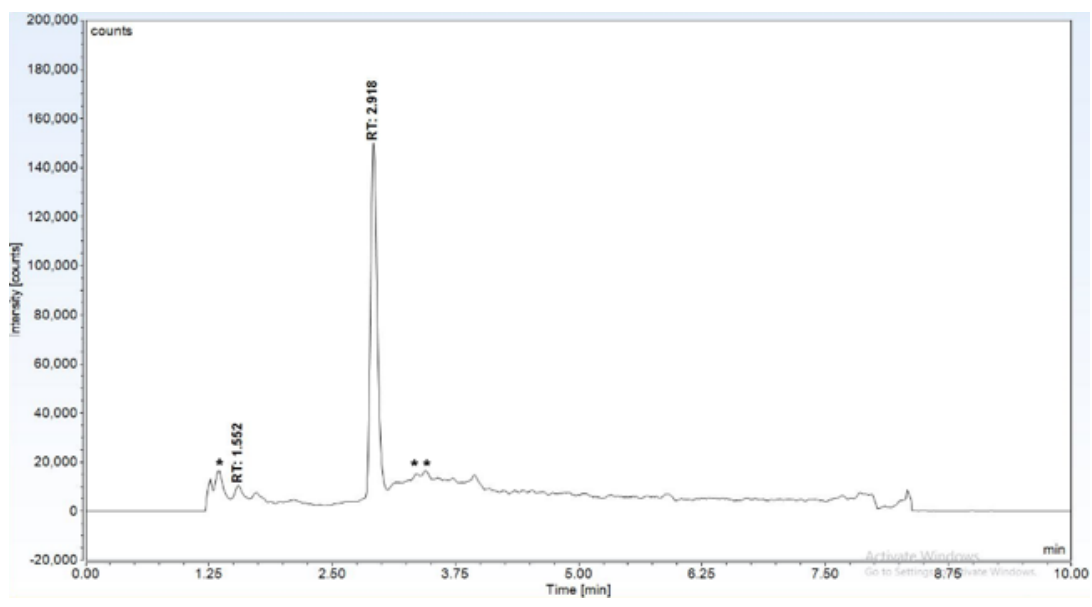

(B)

SJT2-161-A2-60min-rerun \#914-978 RT: 2.84-3.04 AV: 65 NL: 1.72E T: ITMS + p ESI Full ms [500.00-2000.00]

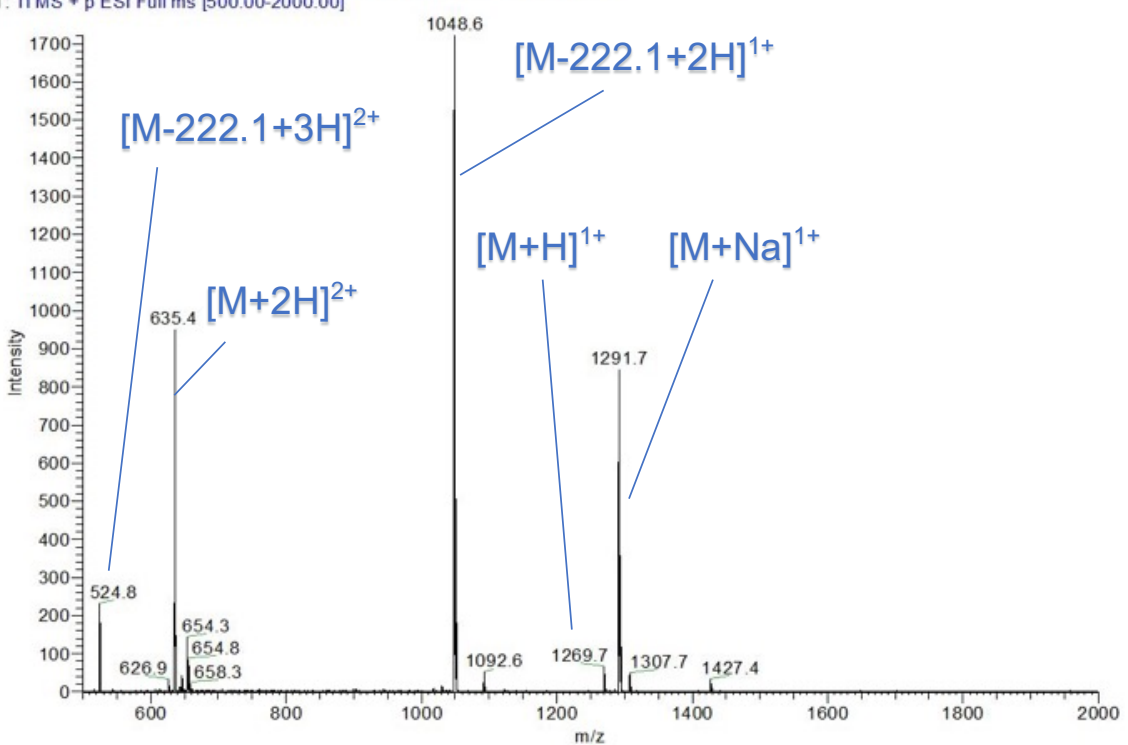

(C)

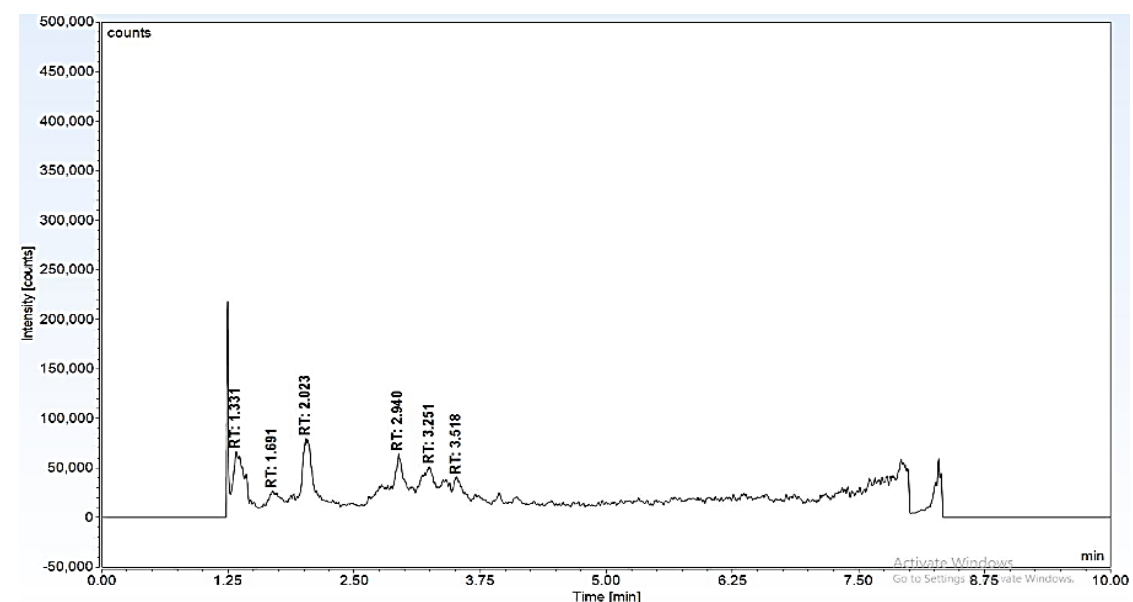

Figure 8. (A) LC/MS of crude reaction between 2 and salt S5. ${ }^{*}=$ byproducts from S5 (B) Mass spectrum of conjugate $2 \mathbf{e}\left(\mathrm{T}_{\mathrm{r}}=2.84-3.04 \mathrm{~min}\right)$. (C) LC/MS trace of irradiated $2 \mathbf{e}$. 


\section{Labeling of Leuprolide with pyridinium salt 1a}

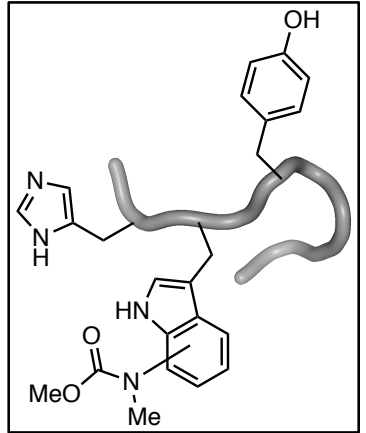

photodegradation.
Labeling of leuprolide with salt $1 \mathrm{a}$ was performed by using leuprolide acetate (3) $(60 \mu \mathrm{L}, 0.1 \mathrm{mM}, 100 \mu \mathrm{M}$ final concentration), 1a $(12 \mu \mathrm{L}, 100$ $\mathrm{mM}, 2 \mathrm{mM}$ final concentration), $\mathrm{NH}_{4} \mathrm{OAc}(60 \mu \mathrm{L}, 200 \mathrm{mM}, \mathrm{pH} 6.9,20 \mathrm{mM}$ final concentration), glutathione $(60 \mu \mathrm{L}, 10 \mathrm{mM}, 1 \mathrm{mM}$ final concentration) and water $(408 \mu \mathrm{L})$ with a 75 minute irradiation time. The reaction mixture was directly analyzed via LC/MS using method $A$ and was judged to have proceeded in $>95 \%$ conversion with a $>20: 1$ mono:di labelling ratio and $7 \%$ of photodegradation.

One replicate reaction was performed using the conditions above with $>95 \%$ conversion with a $>20: 1$ mono:di labelling ratio and $8 \%$ 
(A)

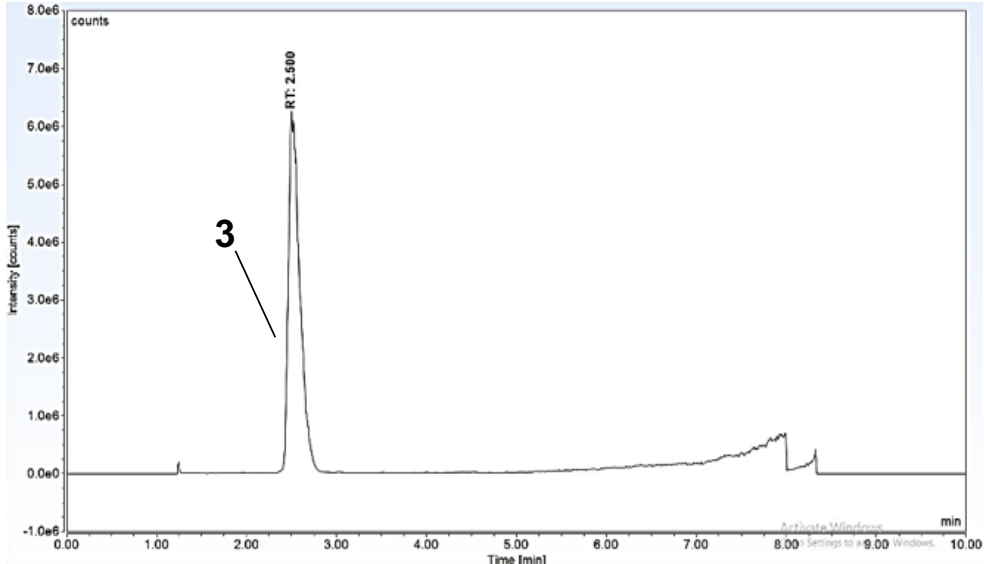

(B)

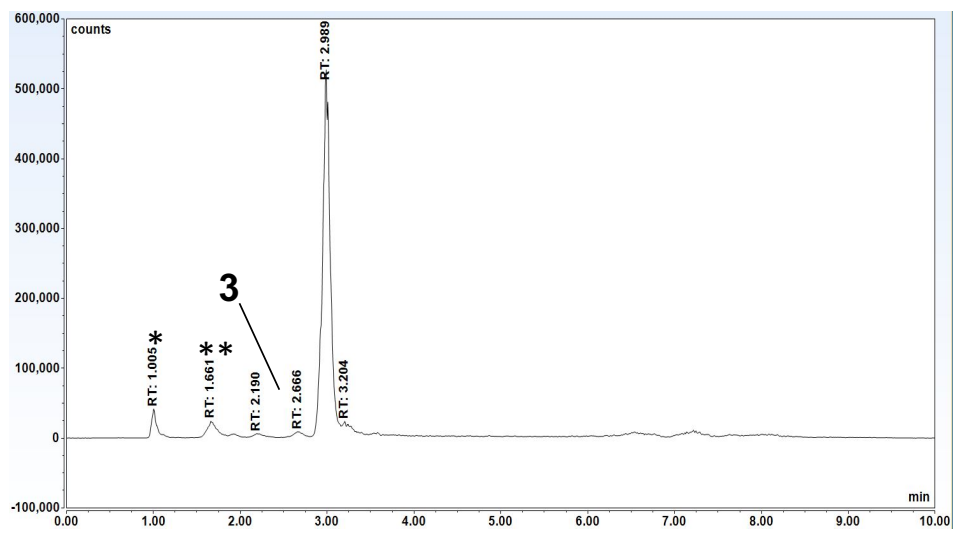

(C)

NJK4 modifiedLeuprolide mecarb 10uLInj \#884-952 RT: $2.75-2.96$ AV: 69 NL: 2.69E T: ITMS + p ESI Full ms [500.00-2000.00]

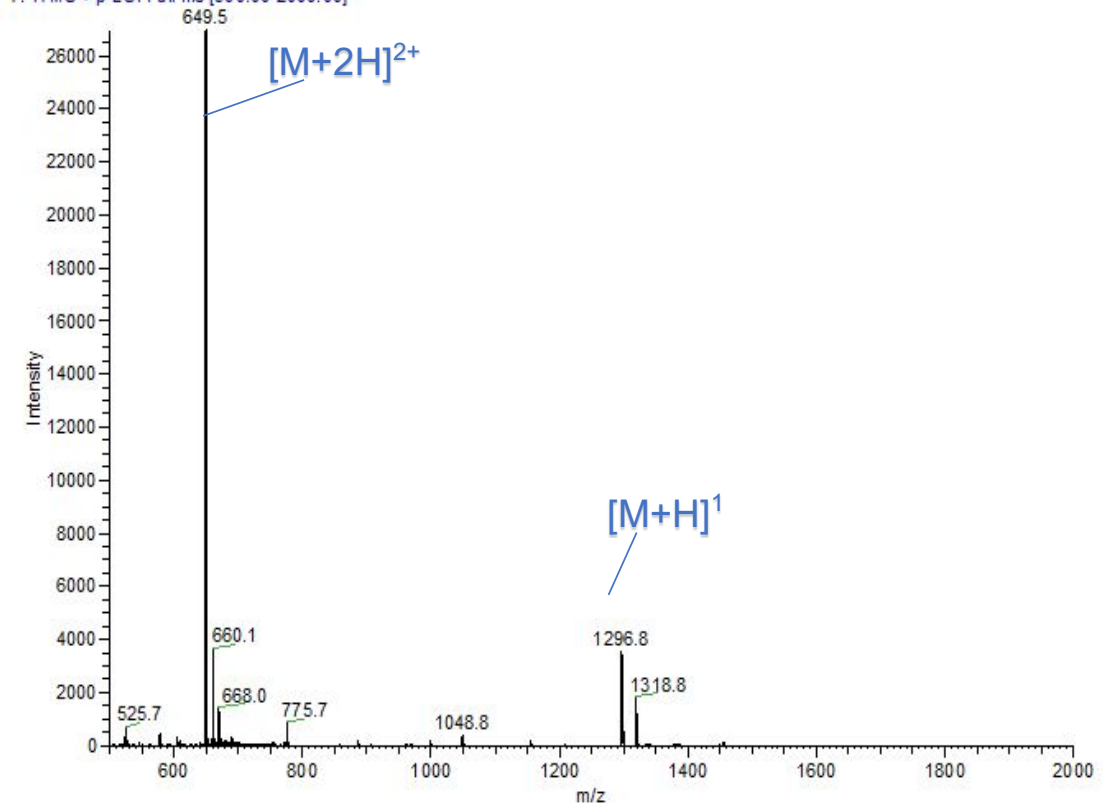

Figure 9. (A) LC/MS of Stock Solution 3. (B) LC/MS of crude reaction between $\mathbf{3}$ and salt $\mathbf{1 a}$. ${ }^{*}=$ glutathione and buffer and ${ }^{* *}=$ photodegradation. $(C)$ Mass spectrum of conjugate $3 a\left(\mathrm{~T}_{\mathrm{r}}=\right.$ 2.88-3.02 $\mathrm{min}$ ). 


\section{Preparative Scale Labeling of Leuprolide (3) with 1a}

Preparative scale labeling of Leuprolide with salt 1a was performed using the following procedure. To a $10 \mathrm{~mL}$ pear-shaped flask equipped with a stir-bar and fitted with a Chemglass air-free Schlenk adapter (item number AF-0501-01) were sequentially added salt 1a (14.8 mg, 50 mmols, $10 \mathrm{mM}$ final concentration), LC/MS grade water $(3.4 \mathrm{~mL}), 3(595 \mu \mathrm{L}, 4.2 \mathrm{mM}, 500 \mu \mathrm{M}$ final concentration), $\mathrm{NH}_{4} \mathrm{OAc}(500 \mu \mathrm{L}, 200 \mathrm{mM}, \mathrm{pH} 6.9,20 \mathrm{mM}$ final concentration), and glutathione $(500 \mu \mathrm{L}, 50 \mathrm{mM}, 5 \mathrm{mM}$ final concentration) to give a final volume of $5 \mathrm{~mL}$. The homogeneous solution was then degassed via iterative freeze, pump, thaw cycles. The flask was then placed $6 \mathrm{~cm}$ above a stir plate and a $302 \mathrm{~nm}$ UV lamp (Analytikjena, UVP 3UV Lamp, $8 \mathrm{~W}$ ) placed $2 \mathrm{~mm}$ away from the flask at an angle that was parallel with the taper of the flask and positioned such that the solution was entirely in the path of the lamp. The solution was then irradiated for 3.5 hourswhile stirring at $800 \mathrm{rpm}$. The reaction mixture was analyzed directly via LC/MS and judged to have proceeded in $91 \%$ conversion, $81 \%$ monolabled modification ( $>20: 1$ Mono:di labeled ratio). The reaction mixture was then purified directly by HPLC using method $A$ to obtain 3a (2.2 mg, $67 \%$ yield). One additional experiment was performed using the same procedure to obtain $79 \%$ isolated yield with an average isolated yield of $73 \%$ between the two experiments. Yields were determined via NMR using $450 \mu \mathrm{M}$ DMF as an internal standard.

\section{(A)}

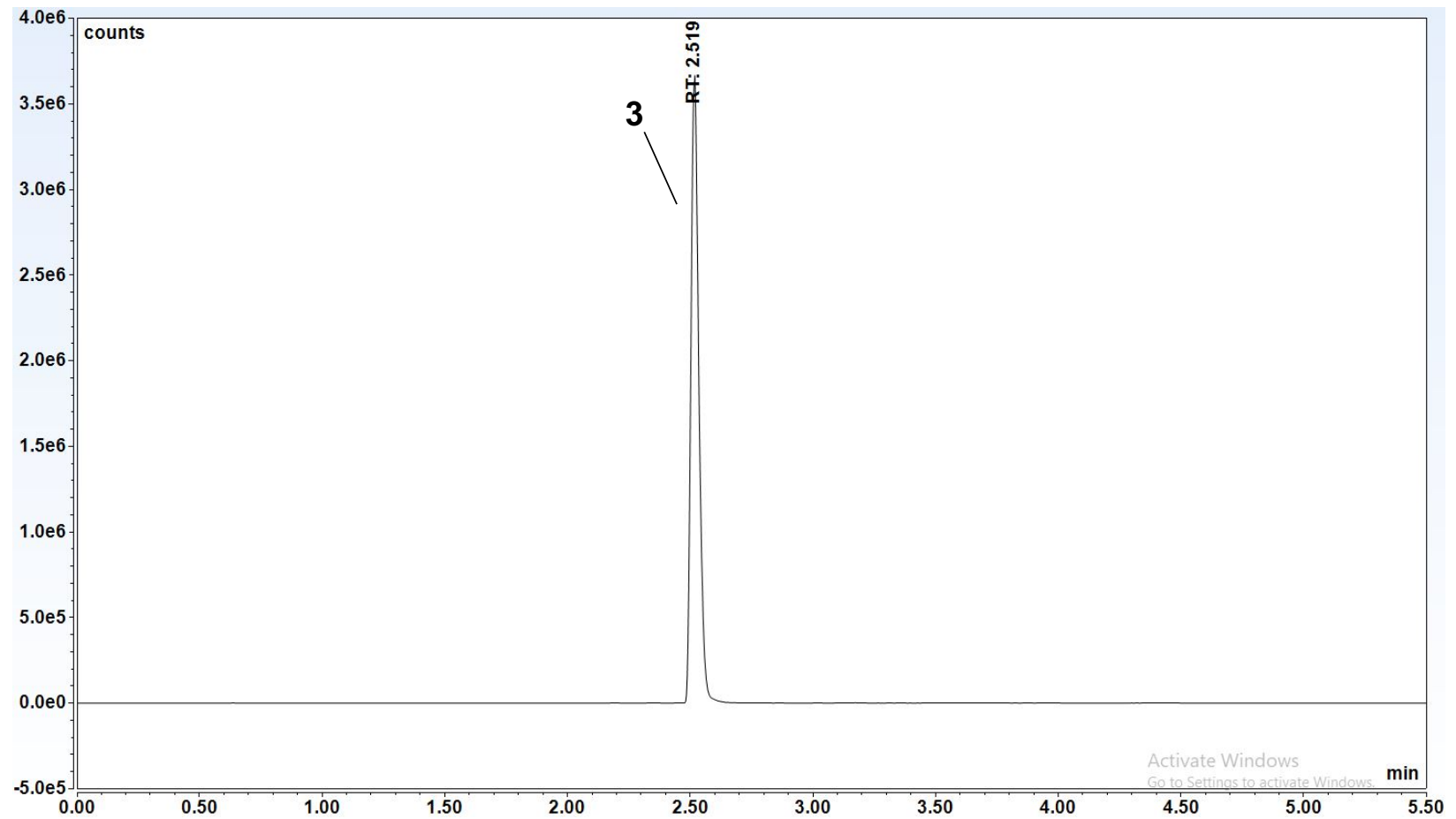


(B)

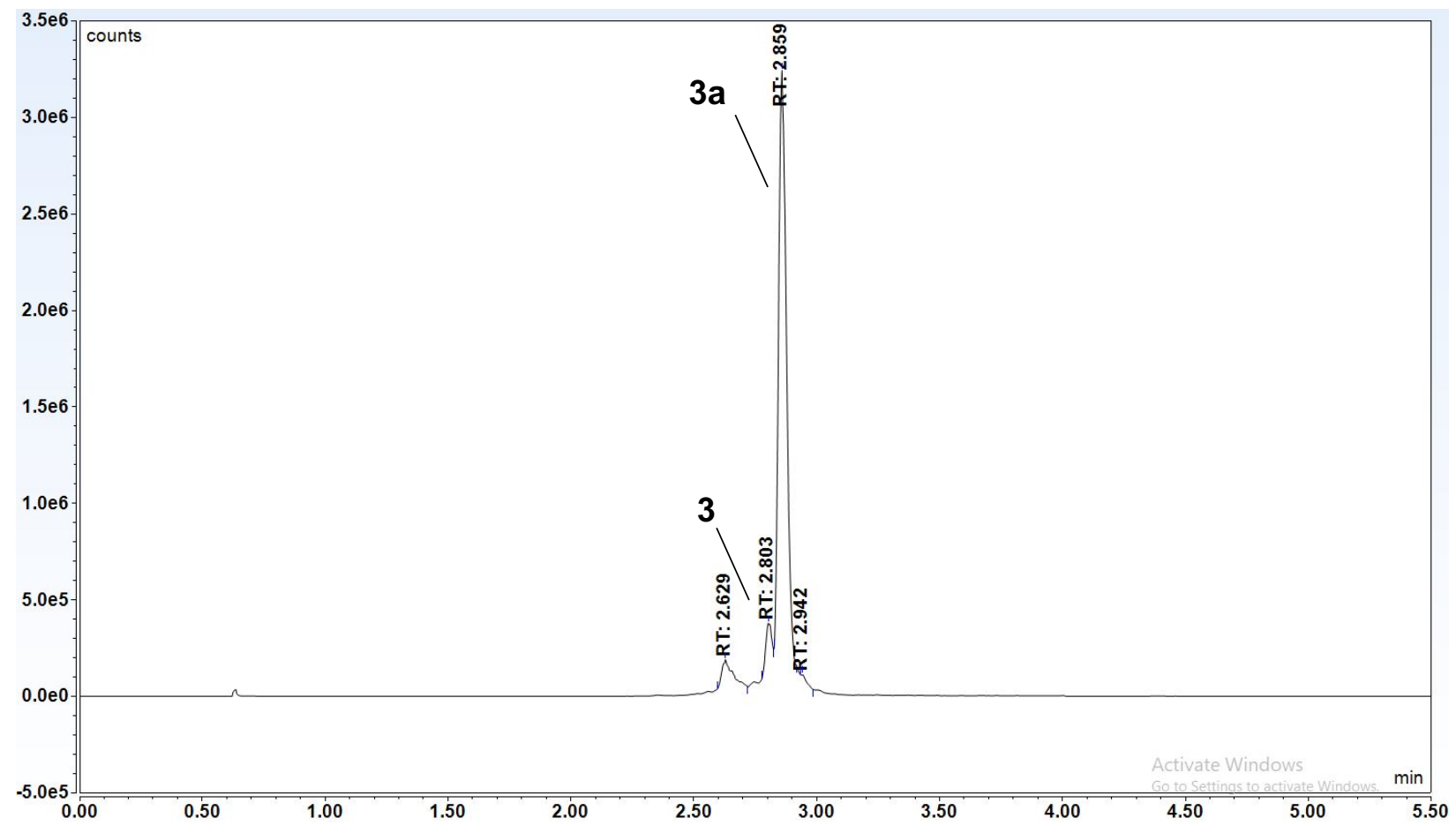

(C)

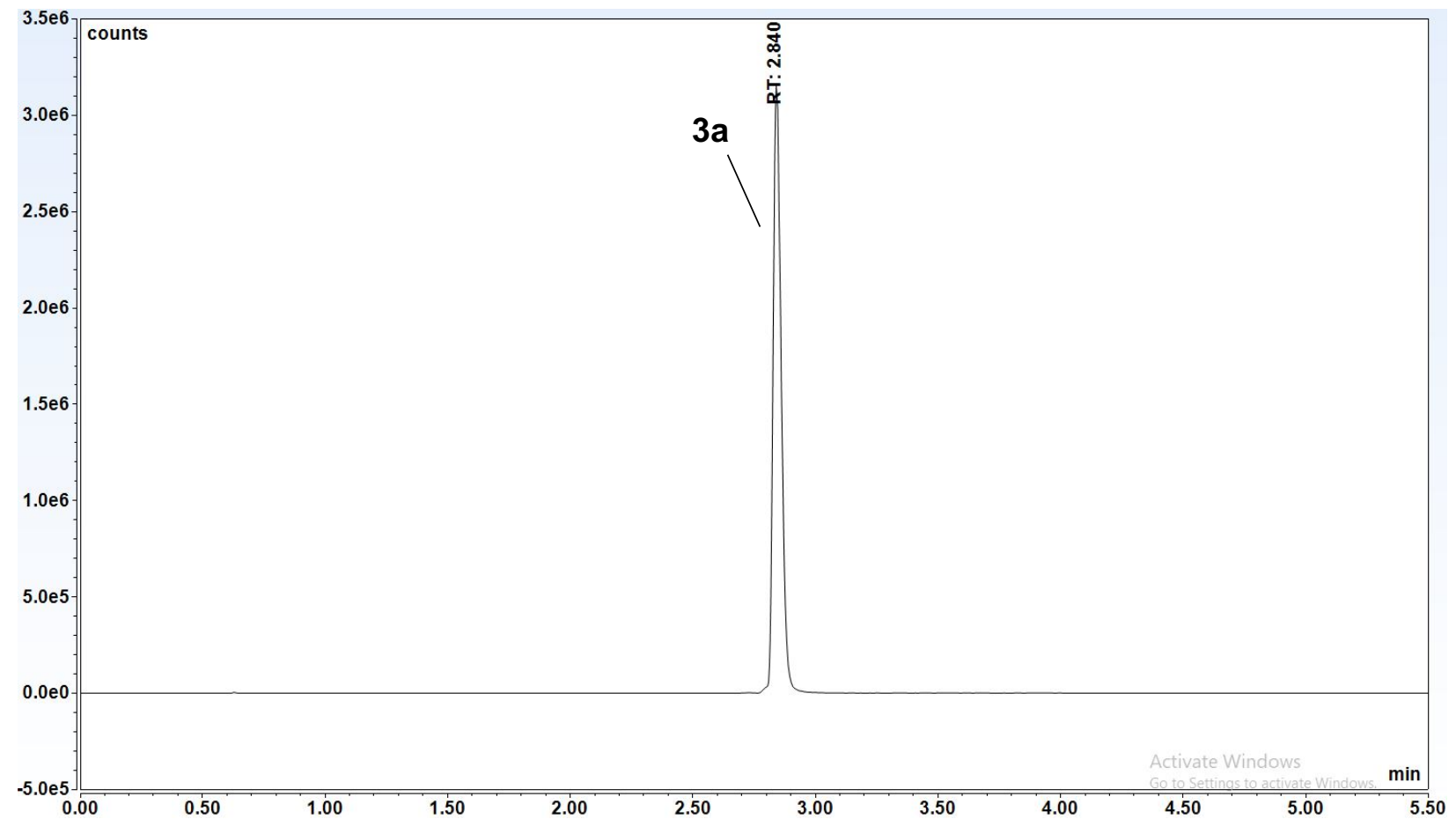


(D)

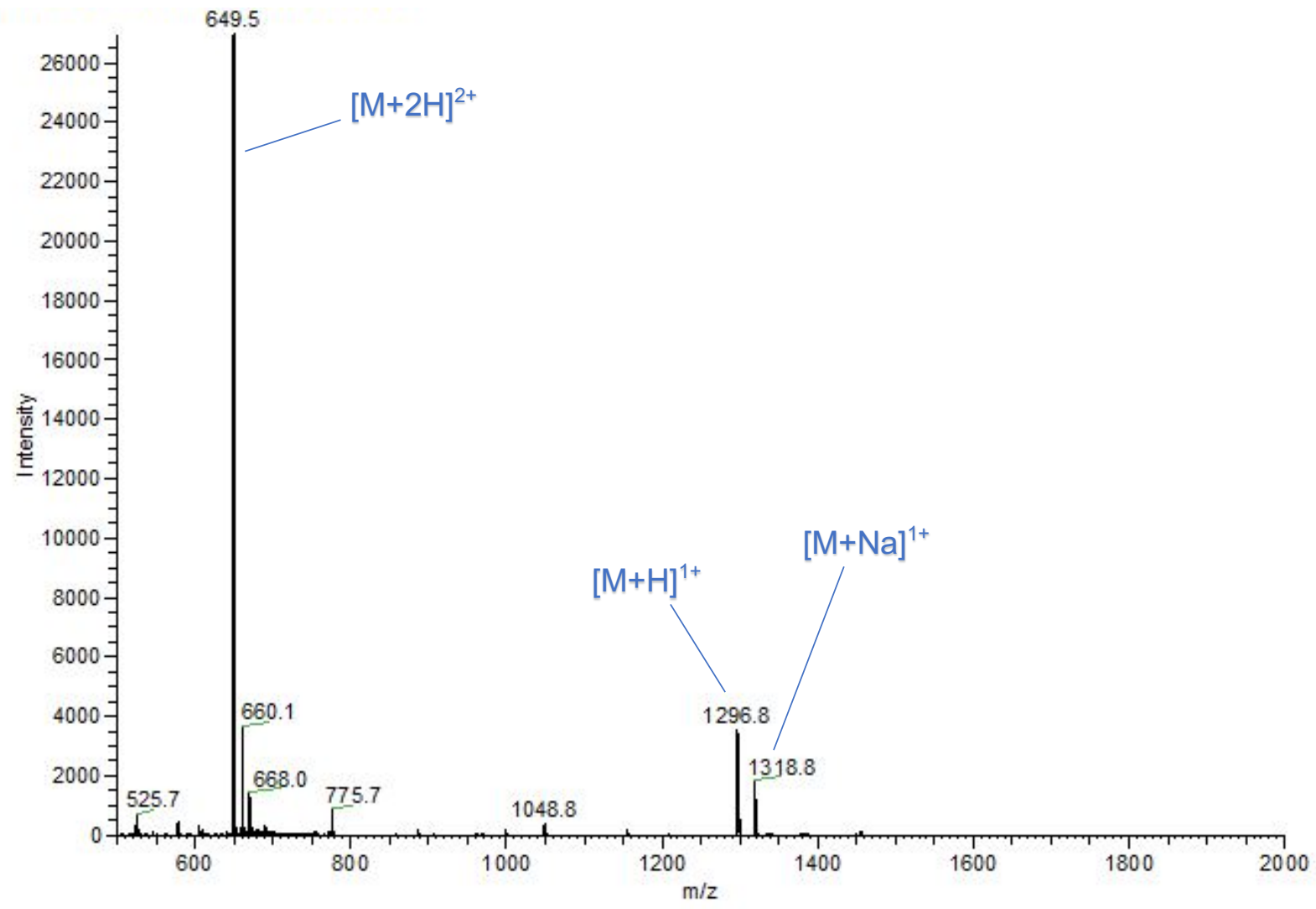

Figure 10. (A) LC/MS chromatogram stock solution of 3 using method $E$. (B) LC/MS of crude reaction mixture using method $\mathrm{E}$. (C) LC/MS chromatogram of isolated $3 a$ using method $E$. (D) Mass spectrum of isolated conjugate $\mathbf{3 a}$. 


\section{Labeling of Daptomycin with pyridinium salt 1a}

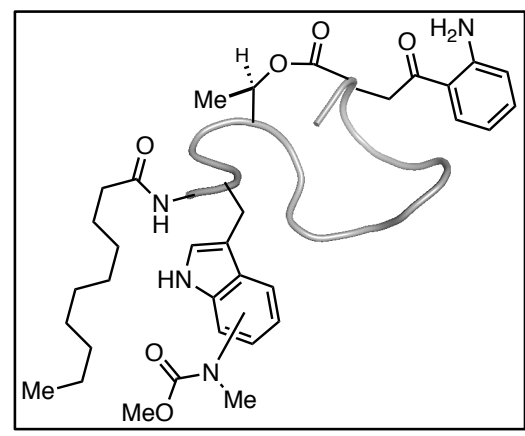

Labeling of daptomycin with salt $1 \mathrm{a}$ was performed using daptomycin (4) (5 $\mathrm{L}, 0.6 \mathrm{mM}, 10 \mu \mathrm{M}$ final concentration), 1a (21 $\mu \mathrm{L}, 100 \mathrm{mM}, 7 \mathrm{mM}$ final concentration), $\mathrm{NH}_{4} \mathrm{OAc}(3 \mu \mathrm{L}, 2 \mathrm{M}, \mathrm{pH}$ 6.9, $20 \mathrm{mM}$ final concentration), glutathione $(3 \mu \mathrm{L}, 100 \mathrm{mM}, 1$ $\mathrm{mM}$ final concentration) and water $(267 \mu \mathrm{L})$ with a 35 minute irradiation time. The reaction mixture was analyzed directly using method B and was judged to have proceeded in $94 \%$ conversion, 85\% mono-labelled, 9\% di-labelled, 9:1 mono:di labeled ratio.

A replicate reaction using $4(5 \mu \mathrm{L}, 0.6 \mathrm{mM}, 10 \mu \mathrm{M}$ final concentration), 1a (42 $\mu \mathrm{L}, 50 \mathrm{mM}, 7 \mathrm{mM}$ final concentration),

$\mathrm{NH}_{4} \mathrm{OAc}(3 \mu \mathrm{L}, 2 \mathrm{M}, \mathrm{pH} 6.9,20 \mathrm{mM}$ final concentration), glutathione $(3 \mu \mathrm{L}, 100 \mathrm{mM}, 1 \mathrm{mM}$ final concentration) and water $(246 \mu \mathrm{L})$ proceeded in $>95 \%$ conversion, $85 \%$ mono-labelled, $11 \%$ dilabelled, 7:1 mono:di labeled ratio. 
(A)

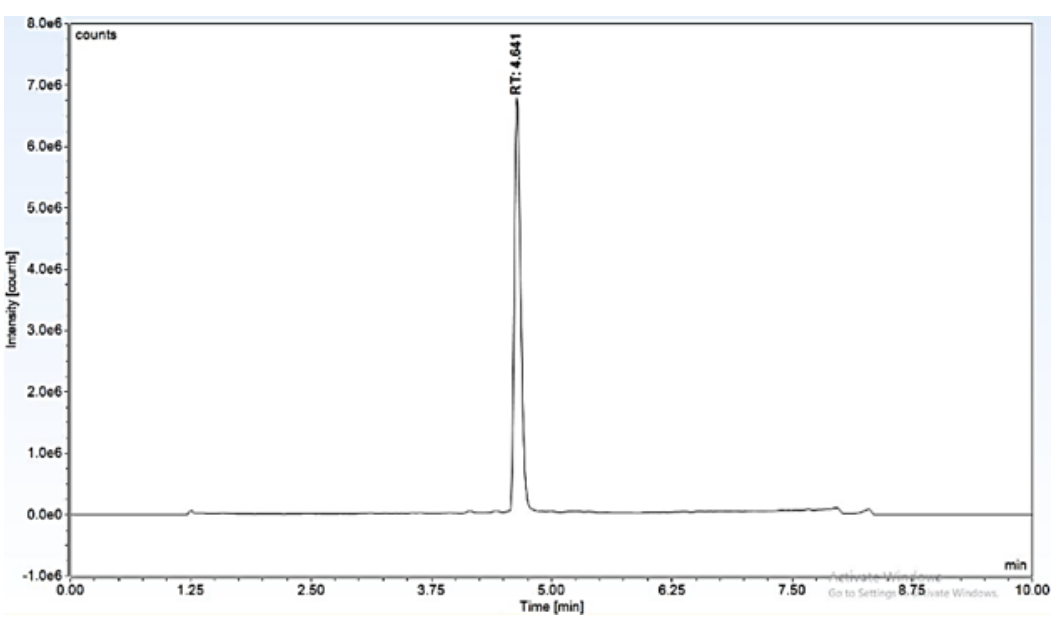

(B)

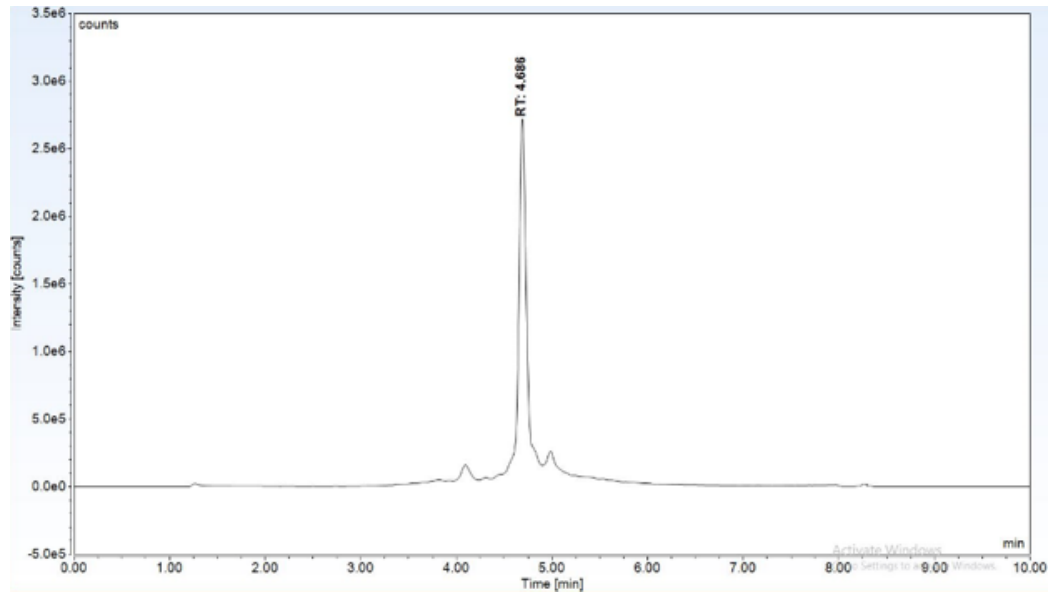

(C)

SJT2-150-C2-35min01 \#1299-1675 RT: 4.04-5.20 AV: 377 NL: 5.78 E3

T: ITMS + p ESI Full ms [500.00-2000.00]

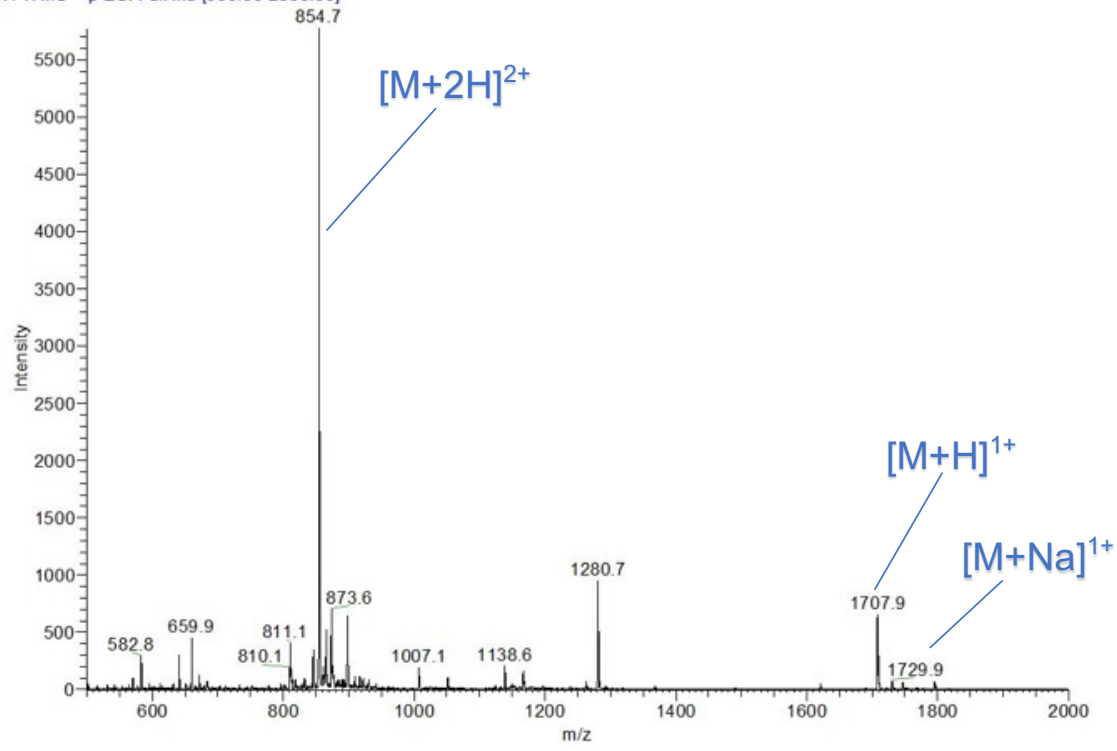

Figure 11 (A) LC/MS of stock solution 4. (B) LC/MS of crude reaction between 4 and salt 1a. (C) Mass spectrum of conjugate $4 a\left(T_{r}=4.04-5.02 \mathrm{~min}\right)$. 


\section{Labeling of Melittin with pyridinium salt 1a}

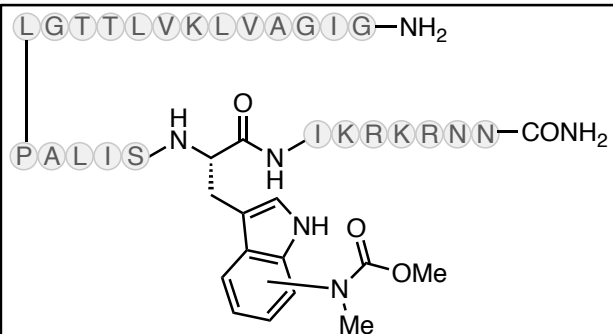

Labeling of melittin with salt 1a was performed using melittin (5) (6 $\mu \mathrm{L}, 3.4 \mathrm{mM}, 67 \mu \mathrm{M}$ final concentration), 1a $\left(21 \mu \mathrm{L}, 100 \mathrm{mM}, 7 \mathrm{mM}\right.$ final concentration), $\mathrm{NH}_{4} \mathrm{OAc}(3 \mu \mathrm{L}$, $2 \mathrm{M}, \mathrm{pH} 6.9,20 \mathrm{mM}$ final concentration), glutathione (3 $\mu \mathrm{L}, 100 \mathrm{mM}, 1 \mathrm{mM}$ final concentration), and water (267 $\mu \mathrm{L}$ ) with a 30 minute irradiation. The reaction mixture was directly analyzed via LC/MS using method B and was judged to have proceeded in $83 \%$ conversion, $78 \%$ 5a, $5 \%$ oxidation, with a $>20: 1$ mono:di labelled ratio.

A replicate reaction with $5(6 \mu \mathrm{L}, 3.4 \mathrm{mM}, 67 \mu \mathrm{M}$ final concentration), $1 \mathrm{a}(21 \mu \mathrm{L}, 100 \mathrm{mM}, 7 \mathrm{mM}$ final concentration), $\mathrm{NH}_{4} \mathrm{OAc}(3 \mu \mathrm{L}, 2 \mathrm{M}, \mathrm{pH} 6.9,20 \mathrm{mM}$ final concentration), glutathione $(3 \mu \mathrm{L}$, $100 \mathrm{mM}, 1 \mathrm{mM}$ final concentration), and water $(267 \mu \mathrm{L})$ proceeded in $85 \%$ conversion, $82 \%$ 5a, $3 \%$ oxidation, with $>20: 1$ mono:di labelled ratio.

(A)

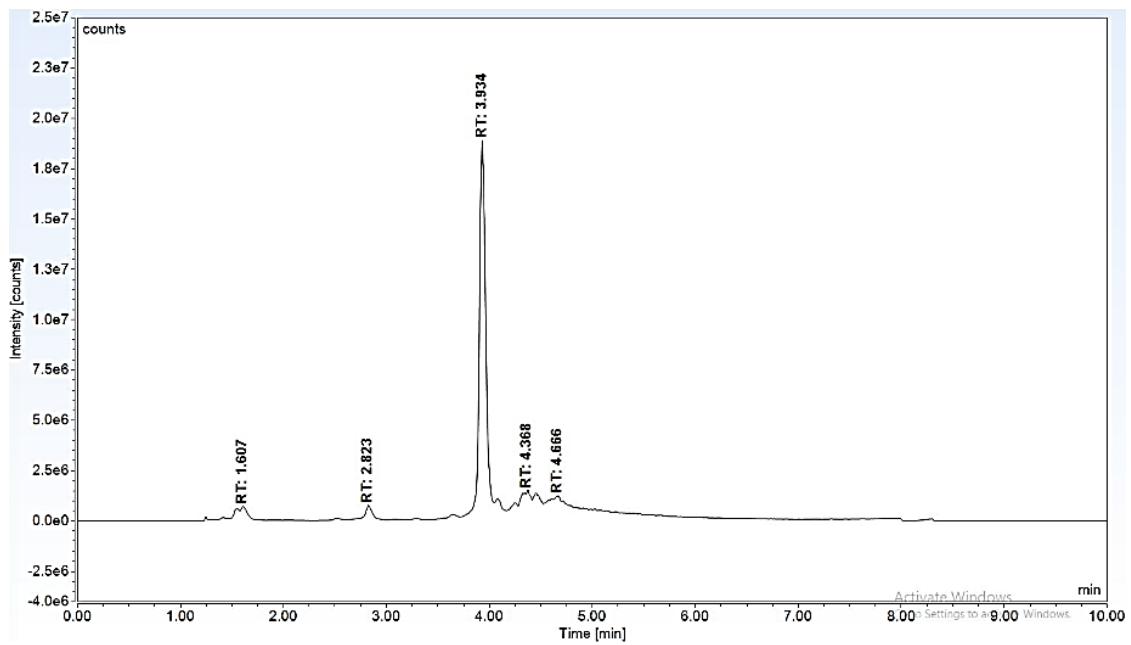

(B)

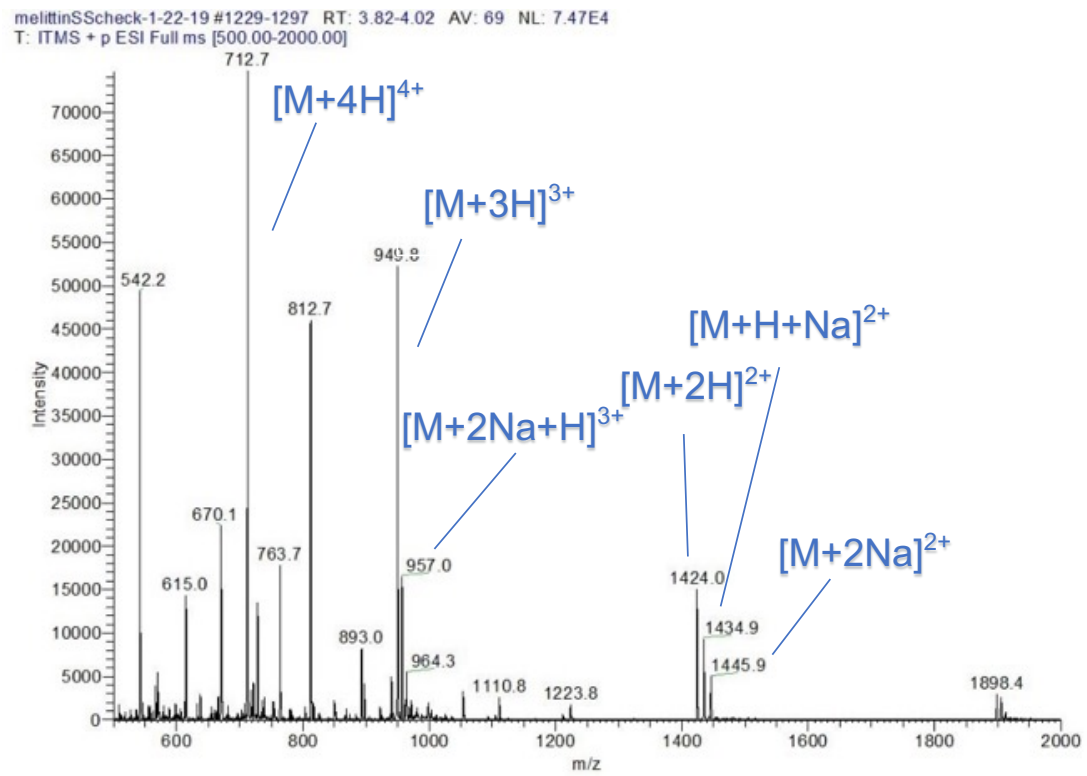


(C)

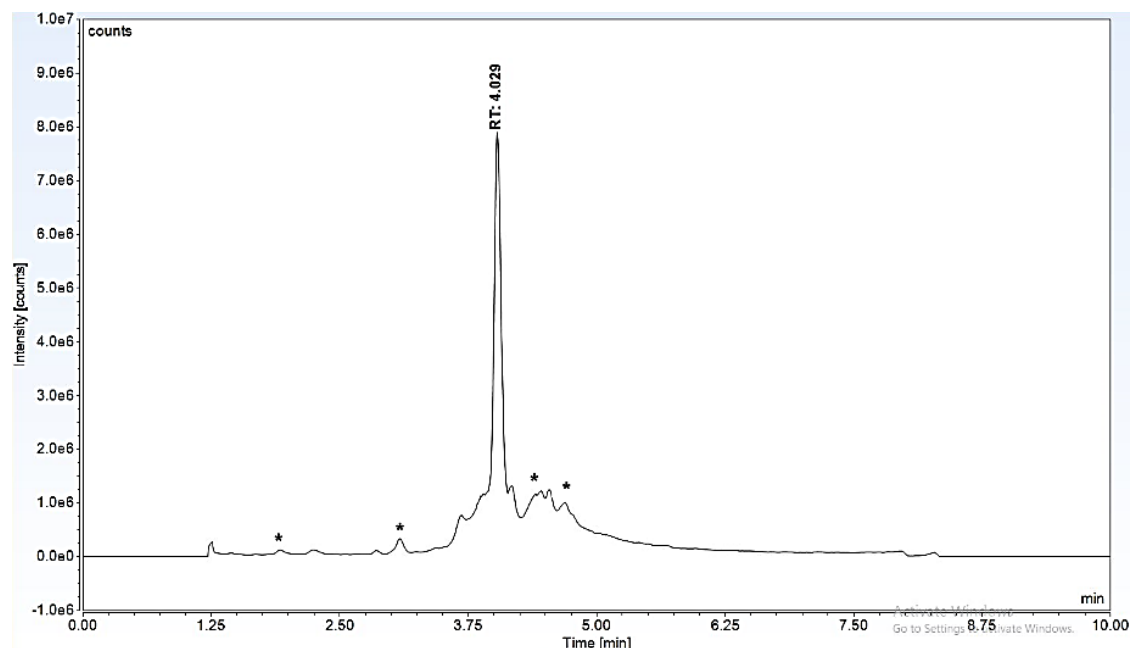

(D)

SJT2-83-A-30min \#1275-1325 RT: 3.96-4.11 AV: $51 \quad$ NL: $3.71 \mathrm{E} 4$

T: ITMS + p ESI Full ms [500.00-2000.00]

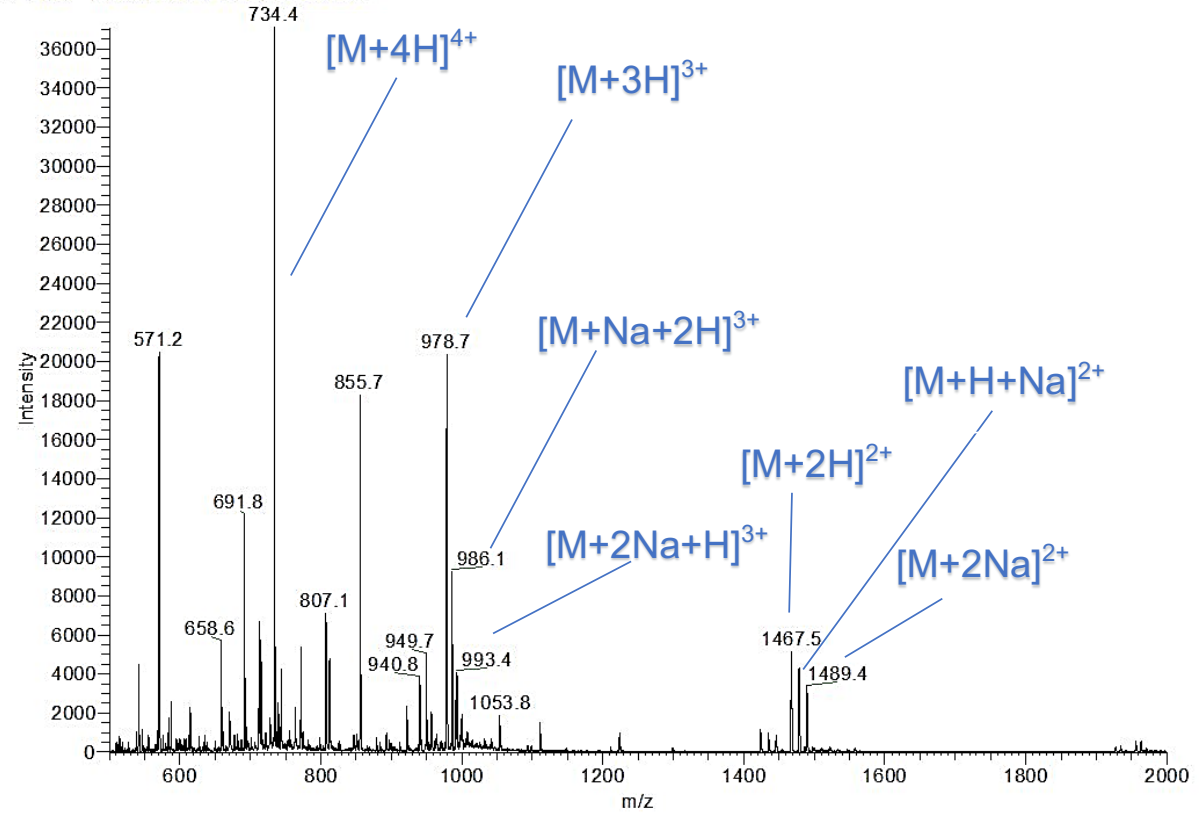

Figure 12. (A) LC/MS of 5. (B) Mass spectrum of 5 ( $\left.T_{r}=3.82-4.02 \mathrm{~min}\right)(\mathrm{C}) \mathrm{LC} / \mathrm{MS}$ of crude reaction between 5 and salt 1a. ${ }^{*}=$ impurities in the stock solution (D) Mass spectrum of conjugate $5 \mathbf{a}\left(\mathrm{T}_{\mathrm{r}}=3.96-4.11 \mathrm{~min}\right)$. 


\section{Labeling of Human Glucagon with pyridinium salt 1a}

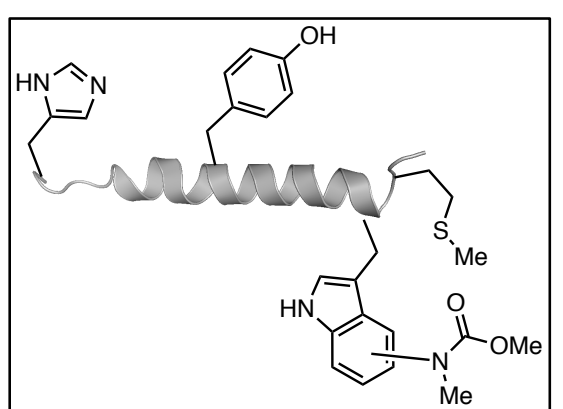

Labeling of human glucagon with salt $1 \mathrm{a}$ was performed using human glucagon (6) $\left(5 \mu \mathrm{L}, 0.6 \mathrm{mM}\right.$ in $20 \mathrm{mM} \mathrm{NH}_{4} \mathrm{OAc}, 10 \mu \mathrm{M}$ final concentration), 1a (60 $\mu \mathrm{L}, 100 \mathrm{mM}$ in $20 \mathrm{mM} \mathrm{NH}_{4} \mathrm{OAc}, 20$ $\mathrm{mM}$ final concentration) glutathione $(3 \mu \mathrm{L}, 100 \mathrm{mM}$ in $20 \mathrm{mM}$ $\mathrm{NH}_{4} \mathrm{OAc}, 1 \mathrm{mM}$ final concentration), TCEP (3 $\mu \mathrm{L}, 100 \mathrm{mM}$ in 20 $\mathrm{mM} \mathrm{NH}{ }_{4} \mathrm{OAc}, 1 \mathrm{mM}$ final concentration) and $\mathrm{NH}_{4} \mathrm{OAc}(229 \mu \mathrm{L}$, $20 \mathrm{mM}, \mathrm{pH} 6.9,20 \mathrm{mM}$ final concentration) with a 30 minute irradiation. The reaction mixture was directly analyzed via LC/MS using method $B$ and was judged to have proceeded in $86 \%$ conversion, $80 \% 6 a, 6 \%$ oxidation, with a $>20: 1$ mono:di

labelled ratio.

A replicate reaction with $6\left(5 \mu \mathrm{L}, 0.6 \mathrm{mM}\right.$ in $20 \mathrm{mM} \mathrm{NH}_{4} \mathrm{OAc}, 10 \mu \mathrm{M}$ final concentration), 1a (60 $\mu \mathrm{L}, 100 \mathrm{mM}$ in $20 \mathrm{mM} \mathrm{NH}_{4} \mathrm{OAc}, 20 \mathrm{mM}$ final concentration), glutathione (3 $\mu \mathrm{L}, 100 \mathrm{mM}$ in $20 \mathrm{mM}$ $\mathrm{NH}_{4} \mathrm{OAc}, 1 \mathrm{mM}$ final concentration), TCEP $\left(3 \mu \mathrm{L}, 100 \mathrm{mM}\right.$ in $20 \mathrm{mM} \mathrm{NH}{ }_{4} \mathrm{OAc}, 1 \mathrm{mM}$ final concentration) and $\mathrm{NH}_{4} \mathrm{OAc}(229 \mu \mathrm{L}, 20 \mathrm{mM}, \mathrm{pH} 6.9,20 \mathrm{mM}$ final concentration) proceeded in a $86 \%$ conversion, $81 \% 6 \mathbf{a}, 5 \%$ oxidation, with $>20: 1$ mono:di labelled ratio. 
(A)

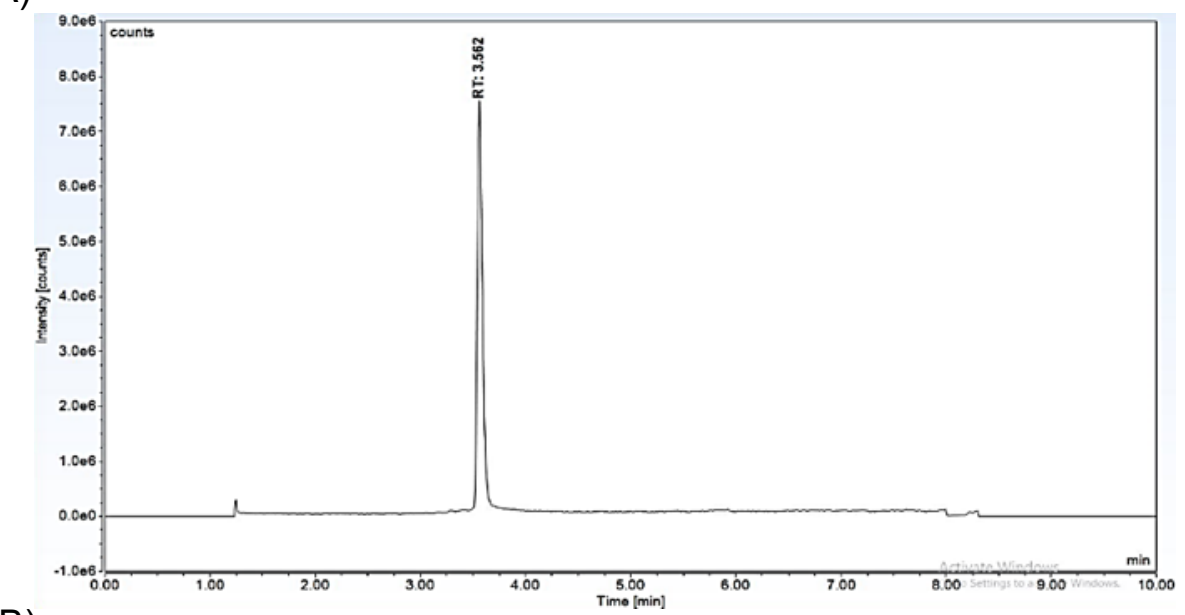

(B)

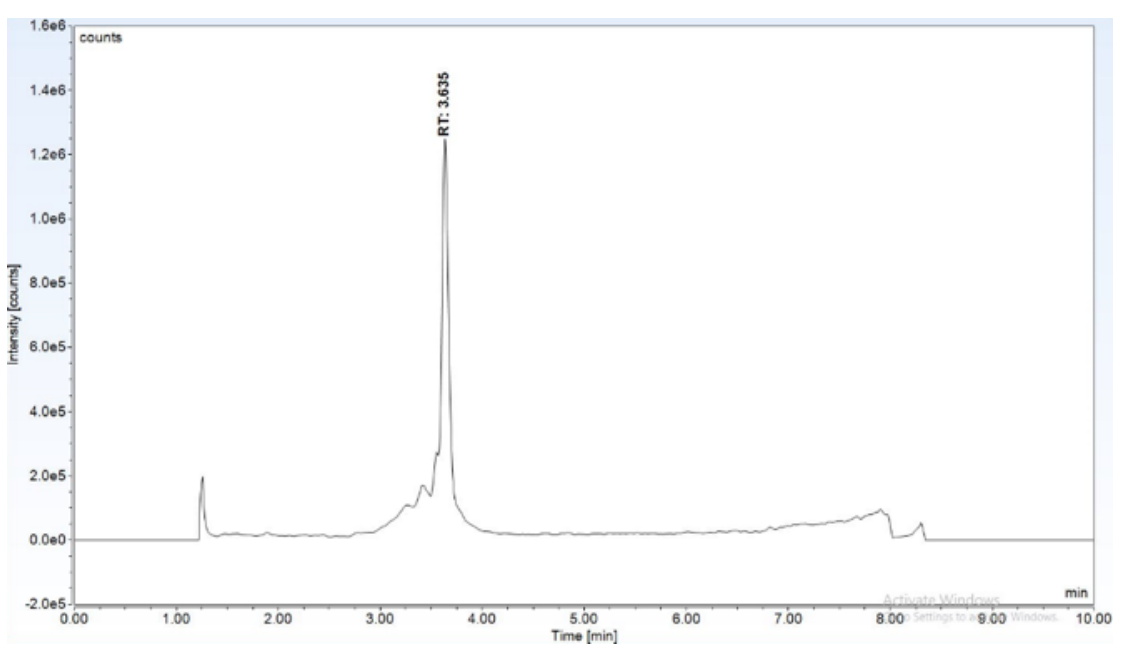

(C)

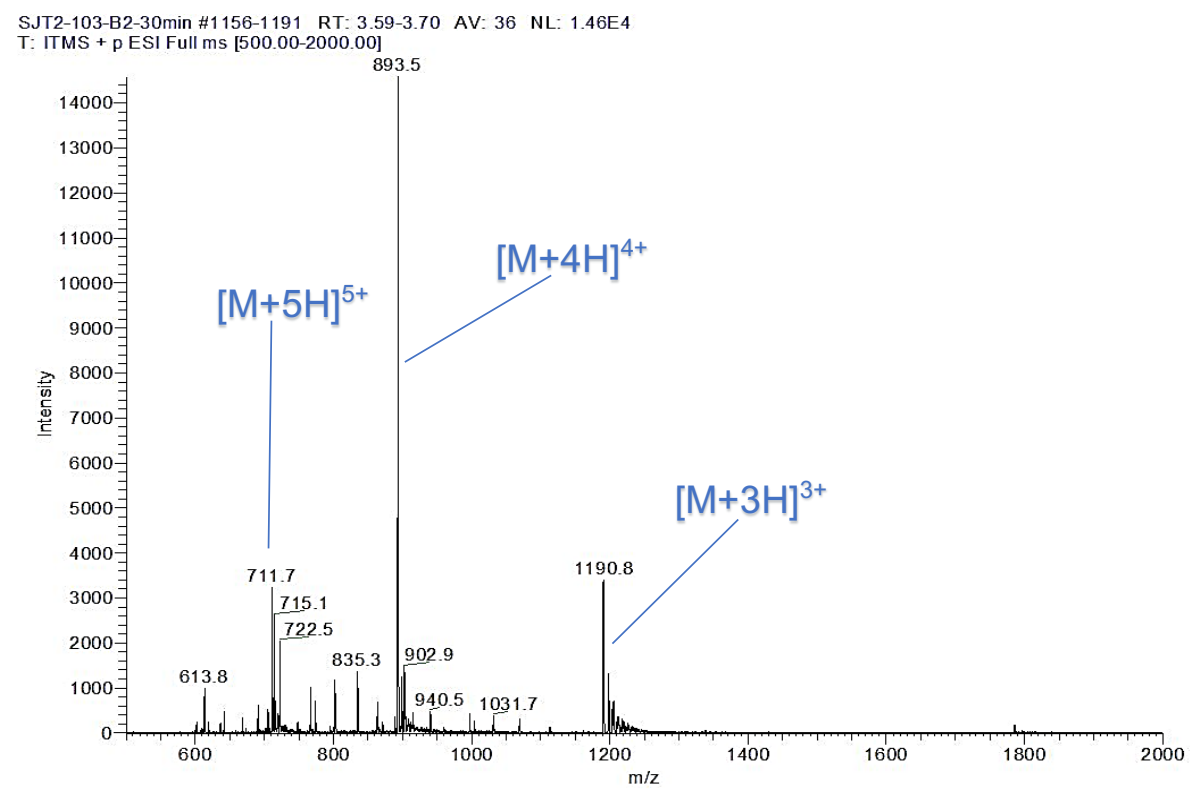

Figure 13. (A) LC/MS of Stock Solution 6. (B) LC/MS of crude reaction between 6 and salt 1 a. (C) Mass spectrum of conjugate $6 a\left(T_{r}=3.59-3.70 \mathrm{~min}\right)$. 


\section{Characterization of labelled protein conjugates by tandem mass spectrometry and circular dichroism, and NMR spectroscopy.}

\section{General Trypsin Digest Protocols:}

Protocol A: For non-cystine bridged labelled proteins, a standard trypsin digest ${ }^{12}$ was modified as follows: the labelled protein solution was diluted with urea $(240 \mu \mathrm{L}, 10 \mathrm{M}, 6 \mathrm{M}$ final concentration), tris base buffer $\left(100 \mu \mathrm{L}, 50 \mathrm{mM}, \mathrm{pH} 8.4,12.5 \mathrm{mM}\right.$ final concentration), $\mathrm{CaCl}_{2}(10 \mu \mathrm{L}, 100 \mathrm{mM}, 2.5$ $\mathrm{mM}$ final concentration), and trypsin protease $(1 \mu \mathrm{L}, 0.5 \mu \mathrm{g} / \mu \mathrm{L}, 0.002 \mu \mathrm{g} / \mu \mathrm{L}$ final concentration) and incubated at $37^{\circ} \mathrm{C}$ for 15 hours. The digested mixture was analyzed directly via LC/MS and MS/MS.

Protocol B: The labelled protein solution was concentrated using an Amicon $10 \mathrm{kDa}$ filter. This concentrate $(40 \mu \mathrm{L})$ was diluted with urea $(240 \mu \mathrm{L}, 10 \mathrm{M}, 6 \mathrm{M}$ final concentration), tris-buffer (100 $\mu \mathrm{L}, 50 \mathrm{mM}, \mathrm{pH} 8.4,12.5 \mathrm{mM}$ final concentration), and TCEP $(20 \mu \mathrm{L}, 100 \mathrm{mM}, 5 \mathrm{mM}$ final concentration). This solution was incubated for 30 minutes at room temperature. Nmethylmaleimide $(20 \mu \mathrm{L}, 150 \mathrm{mM}, 7.1 \mathrm{mM}$ final concentration) was added directly and again incubated 30 minutes at room temperature. The reduced, Cys-capped labelled protein was then concentrated using an Amicon $10 \mathrm{kDa}$ filter (final volume $40 \mu \mathrm{L}$ ). The concentrate was then diluted with urea $(80 \mu \mathrm{L}, 10 \mathrm{M}, 2 \mathrm{M}$ final concentration), tris base buffer $(270 \mu \mathrm{L}, 50 \mathrm{mM}, \mathrm{pH} 8.4,33.8$ $\mathrm{mM}$ final concentration), $\mathrm{CaCl}_{2}(10 \mu \mathrm{L}, 100 \mathrm{mM}, 2.5 \mathrm{mM}$ final concentration), and trypsin protease $\left(1 \mu \mathrm{L}, 0.5 \mu \mathrm{g} / \mu \mathrm{L}, 0.001 \mu \mathrm{g} / \mu \mathrm{L}\right.$ final concentration) and incubated at $37^{\circ} \mathrm{C}$ for 20 hours. Formic acid $(5 \mu \mathrm{L})$ was then transferred in via syringe and briefly agitated prior to analysis by LC/MS and MS/MS. 


\section{Conjugate 2a}

Tandem MS data were obtained via stirring the reaction mixture with excess TCEP for a minimum of 30 minutes after irradiation and analysis. The reduced product was analyzed via $\mathrm{LC}_{\mathrm{MS}}{ }^{2}$ by selecting $\mathrm{m} / \mathrm{z}=554.8$ for collision-induced dissociation (Collision energy $=35 \mathrm{~V}$ ).
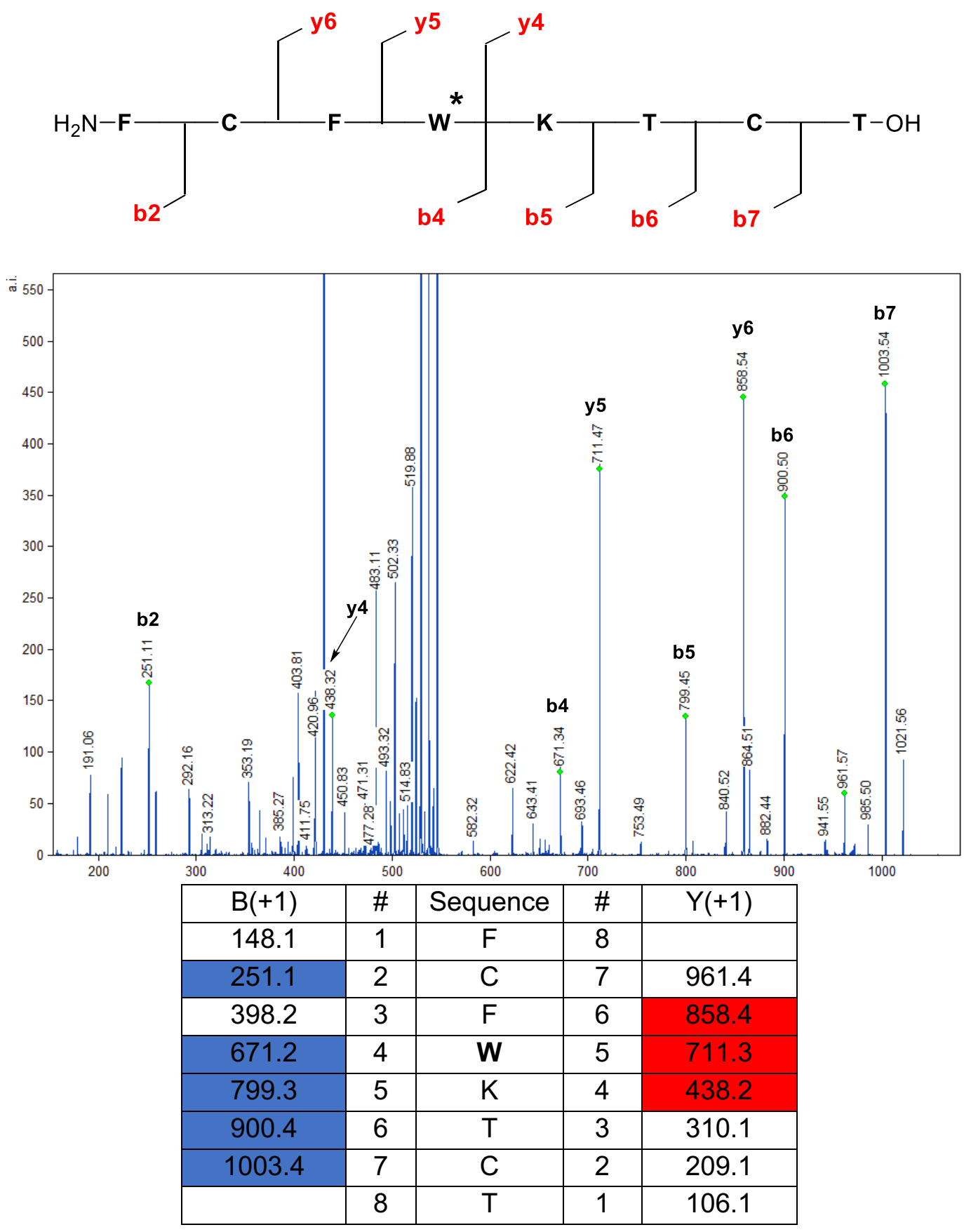


\section{Conjugate 2a Second Label}

In order to increase the prominence of second label, the labeling of $\mathbf{2}$ with salt $\mathbf{1 a}$ was performed using an increased concentration of $1 \mathrm{a}(10 \mathrm{mM}$ final concentration) and phosphate buffer $(\mathrm{pH} 7.5$, $20 \mathrm{mM}$ final concentration) in place of $\mathrm{NH}_{4} \mathrm{OAc}$ with a 60 minute irradiation time. Tandem MS data were obtained via stirring the reaction mixture with excess TCEP for a minimum of 30 minutes after irradiation and analysis. The reduced product was analyzed via LC/MS ${ }^{2}$, by selecting $\mathrm{m} / \mathrm{z}=$ 598.3 for collision-induced dissociation (Collision energy $=35 \mathrm{~V}$ )
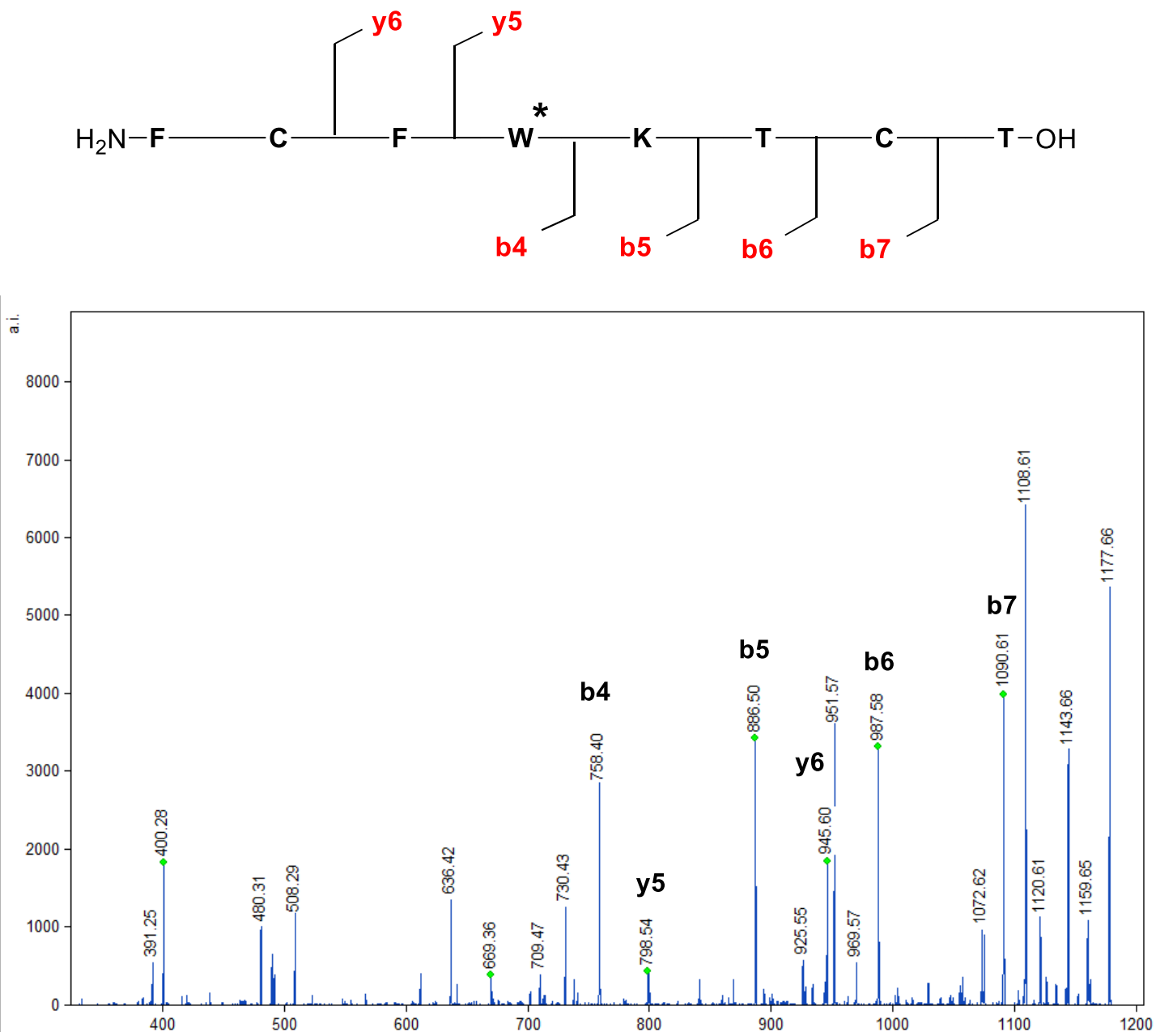

\begin{tabular}{|c|c|c|c|c|}
\hline $\mathrm{B}(+1)$ & $\#$ & Sequence & $\#$ & $\mathrm{Y}(+1)$ \\
\hline 148.1 & 1 & $\mathrm{~F}$ & 8 & \\
\hline 251.1 & 2 & $\mathrm{C}$ & 7 & 1048.4 \\
\hline 398.2 & 3 & $\mathrm{~F}$ & 6 & 945.4 \\
\hline 758.2 & 4 & $\mathrm{~W}$ & 5 & 798.3 \\
\hline 886.3 & 5 & $\mathrm{~K}$ & 4 & 438.2 \\
\hline 987.4 & 6 & $\mathrm{~T}$ & 3 & 310.1 \\
\hline 1090.4 & 7 & $\mathrm{C}$ & 2 & 209.1 \\
\hline & 8 & $\mathrm{~T}$ & 1 & 106.1 \\
\hline
\end{tabular}




\section{Conjugate 3a}

Tandem MS data was obtained via $\mathrm{LC} / \mathrm{MS}^{2}$, by selecting $\mathrm{m} / \mathrm{z}=692.5$ for collision-induced dissociation (Collision energy $=35 \mathrm{~V}$ ).
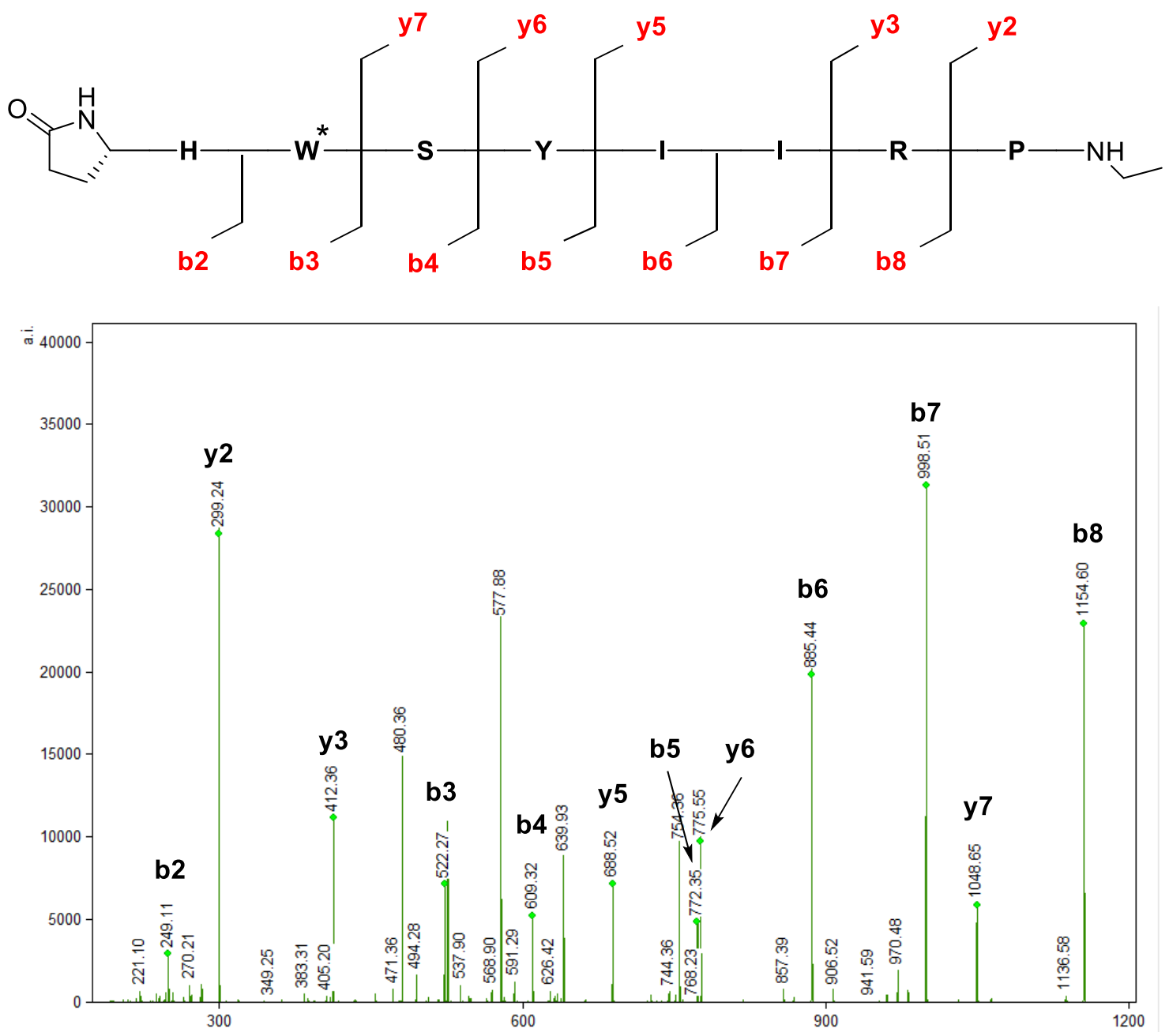

\begin{tabular}{|c|c|c|c|c|}
\hline B & $\#$ & Sequence & $\#$ & $\mathrm{Y}$ \\
\hline 112.0 & 1 & Glp & 9 & \\
\hline 249.1 & 2 & $\mathrm{H}$ & 8 & 1296.6 \\
\hline 522.2 & 3 & $\mathbf{W}$ & 7 & 1048.5 \\
\hline 609.2 & 4 & $\mathrm{~S}$ & 6 & 775.4 \\
\hline 772.3 & 5 & $\mathrm{Y}$ & 5 & 688.4 \\
\hline 885.4 & 6 & $\mathrm{I}$ & 4 & 525.3 \\
\hline 998.5 & 7 & $\mathrm{I}$ & 3 & 412.3 \\
\hline 1154.6 & 8 & $\mathrm{R}$ & 2 & 299.2 \\
\hline & 9 & $\mathrm{P}$ & 1 & 143.1 \\
\hline
\end{tabular}




\section{Conjugate 4a}

Tandem MS data was obtained via $\mathrm{LC} / \mathrm{MS}^{2}$ by selecting $\mathrm{m} / \mathrm{z}=854.5$ for collision-induced dissociation (Collision energy $=35 \mathrm{~V}$ ).

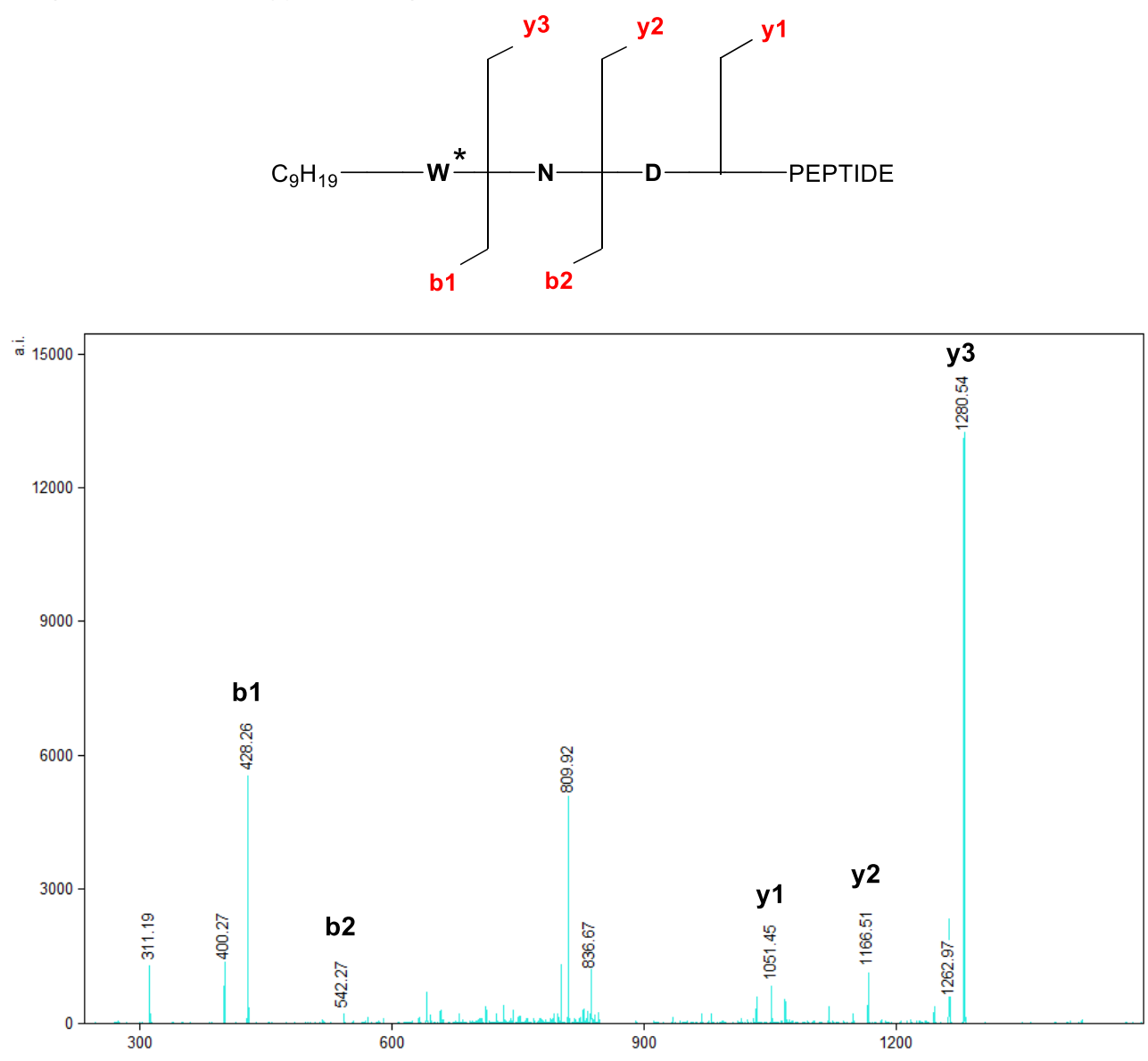

\begin{tabular}{|c|c|c|c|c|}
\hline $\mathrm{B}(+1)$ & $\#$ & Sequence & $\#$ & $\mathrm{Y}(+1)$ \\
\hline 428.1 & 1 & $\mathbf{W}$ & 3 & 1280.5 \\
\hline 542.1 & 2 & $\mathrm{~N}$ & 2 & 1166.5 \\
\hline 657.3 & 3 & $\mathrm{D}$ & 1 & 1051.4 \\
\hline
\end{tabular}




\section{Conjugate 5a}

Tandem MS data was obtained after analysis of the Protocol A digestion via LC/MS by selecting $\mathrm{m} / \mathrm{z}=800.6$ for collision-induced dissociation (Collision energy $=35 \mathrm{~V}$ ).
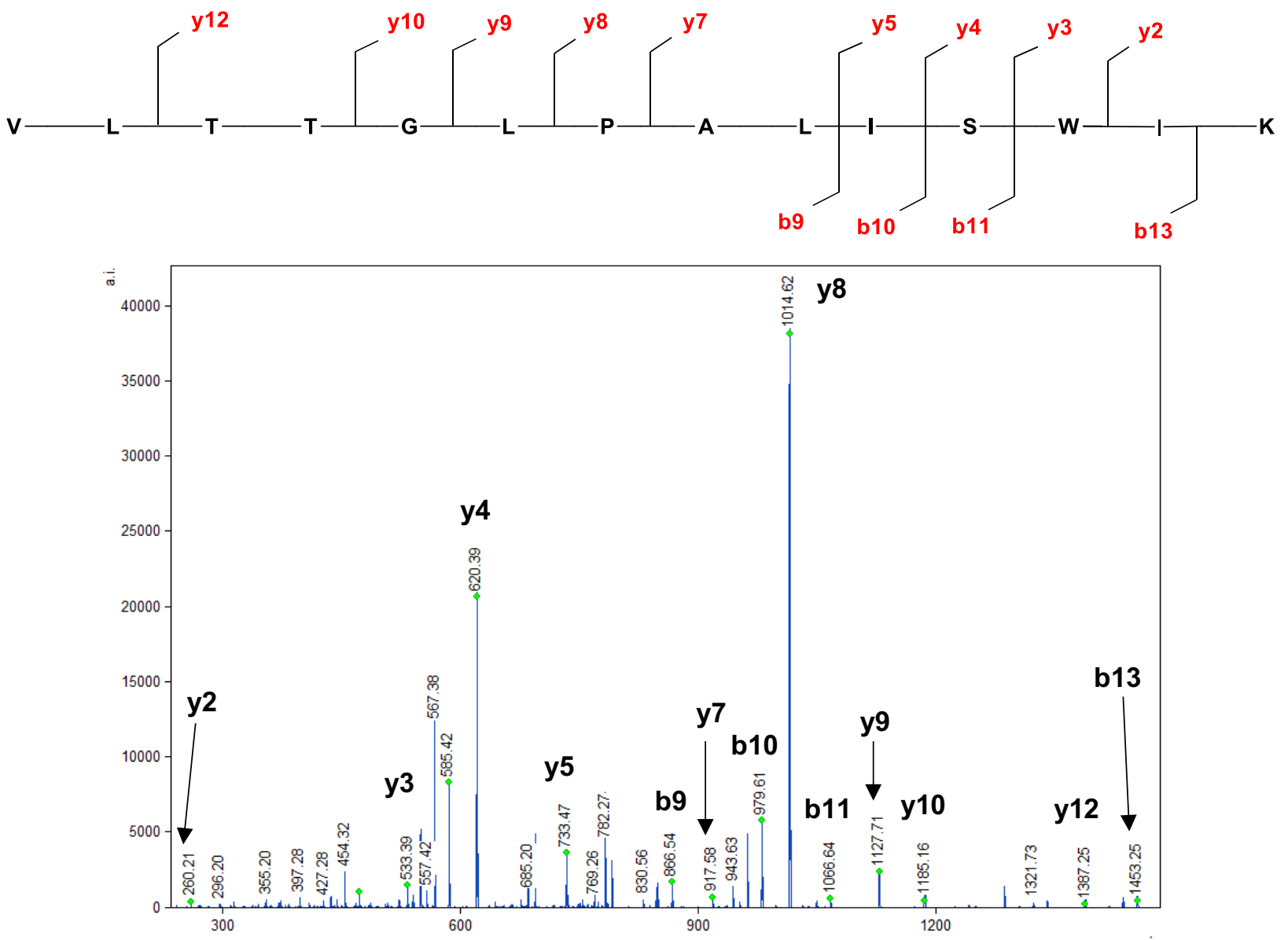

\begin{tabular}{|c|c|c|c|c|}
\hline $\mathrm{B}(+1)$ & $\#$ & Sequence & $\#$ & $\mathrm{Y}(+1)$ \\
\hline & 1 & $\mathrm{~V}$ & 14 & \\
\hline 213.2 & 2 & $\mathrm{~L}$ & 13 & 1499.9 \\
\hline 314.2 & 3 & $\mathrm{~T}$ & 12 & 1386.8 \\
\hline 415.3 & 4 & $\mathrm{~T}$ & 11 & 1285.7 \\
\hline 472.3 & 5 & $\mathrm{G}$ & 10 & 1184.7 \\
\hline 585.4 & 6 & $\mathrm{~L}$ & 9 & 1127.7 \\
\hline 682.4 & 7 & $\mathrm{P}$ & 8 & 1014.6 \\
\hline 753.5 & 8 & $\mathrm{~A}$ & 7 & 917.5 \\
\hline 866.5 & 9 & $\mathrm{~L}$ & 6 & 846.5 \\
\hline 979.6 & 10 & $\mathrm{I}$ & 5 & 733.4 \\
\hline 1066.7 & 11 & $\mathrm{~S}$ & 4 & 620.3 \\
\hline 1339.7 & 12 & $\mathbf{W}$ & 3 & 533.3 \\
\hline 1452.8 & 13 & $\mathrm{I}$ & 2 & 260.2 \\
\hline & 14 & $\mathrm{~K}$ & 1 & 147.1 \\
\hline
\end{tabular}




\section{Conjugate 6a}

Tandem MS data was obtained after analysis of the Protocol A digestion via LC/MS by selecting $\mathrm{m} / \mathrm{z}=720.4$ for collision-induced dissociation (Collision energy $=35 \mathrm{~V}$ ).
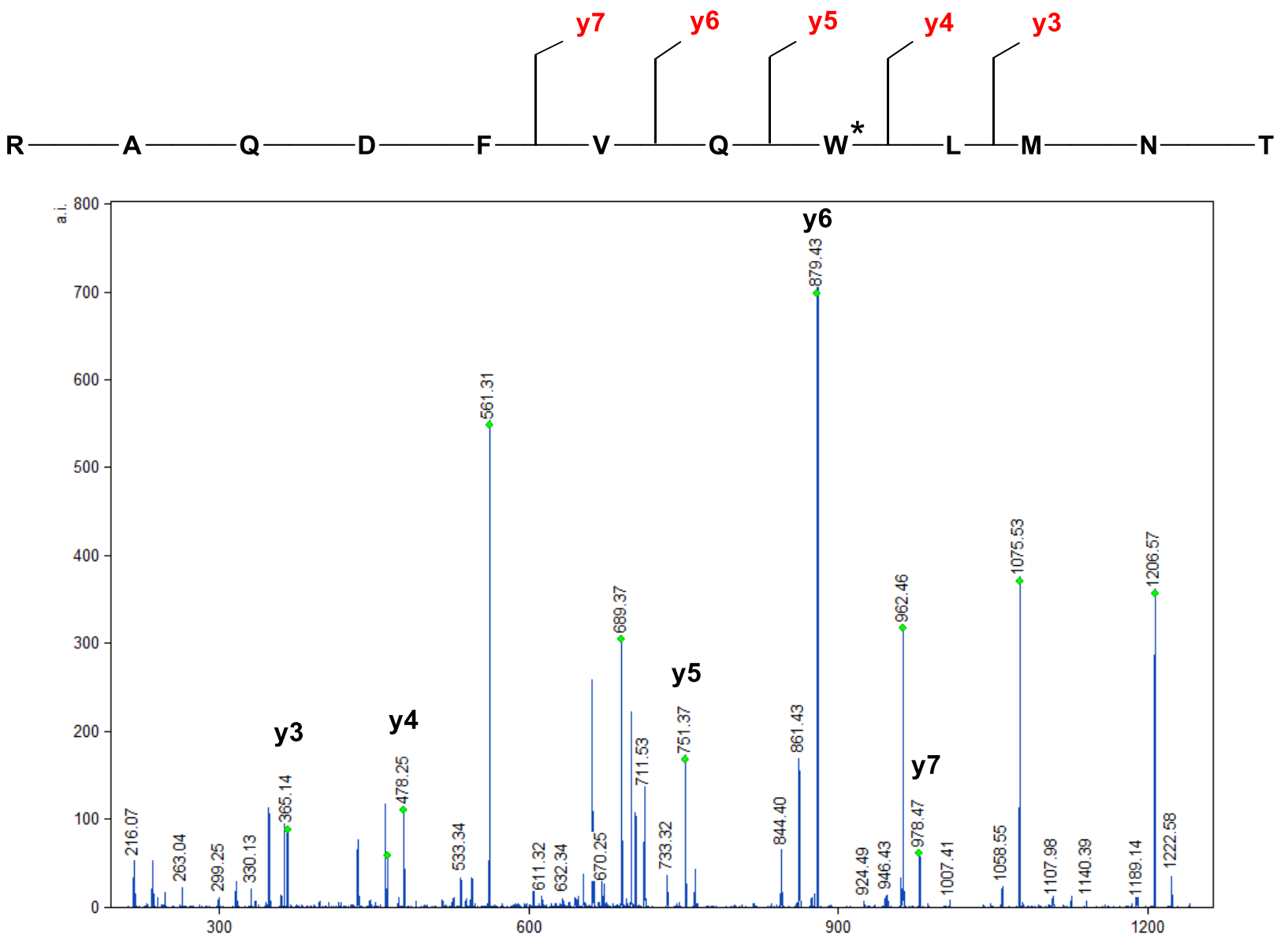

\begin{tabular}{|c|c|c|c|c|}
\hline $\mathrm{B}(+1)$ & $\#$ & Sequence & $\#$ & $\mathrm{Y}(+1)$ \\
\hline 157.1 & 1 & $\mathrm{R}$ & 12 & 1595.7 \\
\hline 228.1 & 2 & $\mathrm{~A}$ & 11 & 1439.6 \\
\hline 356.2 & 3 & $\mathrm{Q}$ & 10 & 1368.6 \\
\hline 471.2 & 4 & $\mathrm{D}$ & 9 & 1240.5 \\
\hline 618.3 & 5 & $\mathrm{~F}$ & 8 & 1125.5 \\
\hline 717.4 & 6 & $\mathrm{~V}$ & 7 & 978.4 \\
\hline 845.4 & 7 & $\mathrm{Q}$ & 6 & 879.4 \\
\hline 1118.5 & 8 & $\mathrm{~W}$ & 5 & 751.3 \\
\hline 1231.6 & 9 & $\mathrm{~L}$ & 4 & 478.2 \\
\hline 1362.6 & 10 & $\mathrm{M}$ & 3 & 365.1 \\
\hline 1476.7 & 11 & $\mathrm{~N}$ & 2 & 234.1 \\
\hline 1577.7 & 12 & $\mathrm{~T}$ & 1 & 120.1 \\
\hline
\end{tabular}




\section{Conjugate 7a}

Tandem MS data was obtained after analysis of the Protocol B digestion via LC/MS by selecting $\mathrm{m} / \mathrm{z}=957.6$ for collision-induced dissociation (Collision energy $=35 \mathrm{~V}$ ).
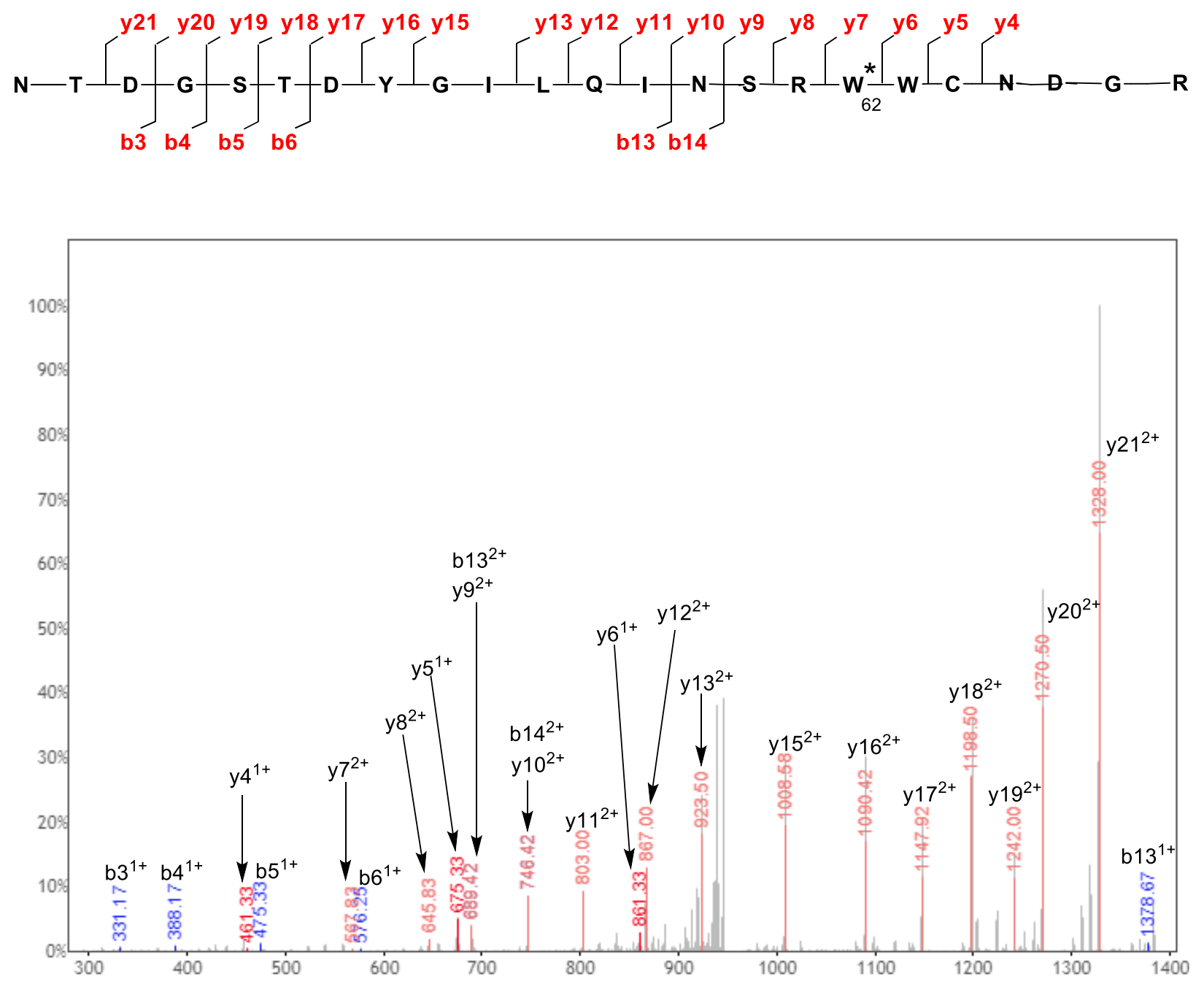


\begin{tabular}{|c|c|c|c|c|c|c|}
\hline $\mathrm{B}(+2)$ & $\mathrm{B}(+1)$ & $\#$ & Sequence & $\#$ & $\mathrm{Y}(+1)$ & $\mathrm{Y}(+2)$ \\
\hline 58.0 & 115.1 & 1 & $\mathrm{~N}$ & 23 & & \\
\hline 108.6 & 216.1 & 2 & $\mathrm{~T}$ & 22 & 2755.2 & 1378.1 \\
\hline 166.1 & 331.1 & 3 & $\mathrm{D}$ & 21 & 2654.1 & 1327.6 \\
\hline 194.6 & 388.1 & 4 & $\mathrm{G}$ & 20 & 2539.1 & 1270.0 \\
\hline 238.1 & 475.2 & 5 & $\mathrm{~S}$ & 19 & 2482.1 & 1241.5 \\
\hline 288.6 & 576.2 & 6 & $\mathrm{~T}$ & 18 & 2395.0 & 1198.0 \\
\hline 346.1 & 691.3 & 7 & $\mathrm{D}$ & 17 & 2294.0 & 1147.5 \\
\hline 427.7 & 854.3 & 8 & $\mathrm{Y}$ & 16 & 2178.9 & 1090.0 \\
\hline 456.2 & 911.3 & 9 & $\mathrm{G}$ & 15 & 2015.9 & 1008.4 \\
\hline 512.7 & 1024.4 & 10 & $\mathrm{I}$ & 14 & 1958.9 & 979.9 \\
\hline 569.3 & 1137.5 & 11 & $\mathrm{~L}$ & 13 & 1845.8 & 923.4 \\
\hline 633.3 & 1265.6 & 12 & $\mathrm{Q}$ & 12 & 1732.7 & 866.9 \\
\hline 689.8 & 1378.6 & 13 & $\mathrm{I}$ & 11 & 1604.6 & 802.8 \\
\hline 746.8 & 1492.7 & 14 & $\mathrm{~N}$ & 10 & 1491.6 & 746.3 \\
\hline 790.4 & 1579.7 & 15 & $\mathrm{~S}$ & 9 & 1377.5 & 689.3 \\
\hline 868.4 & 1735.8 & 16 & $\mathrm{R}$ & 8 & 1290.5 & 645.7 \\
\hline 1005.0 & 2008.9 & 17 & $\mathrm{~W}$ & 7 & 1134.4 & 567.7 \\
\hline 1098.0 & 2195.0 & 18 & $\mathrm{~W}$ & 6 & 861.3 & 431.2 \\
\hline 1205.0 & 2409.0 & 19 & $\mathrm{C}$ & 5 & 675.2 & 338.1 \\
\hline 1262.0 & 2523.0 & 20 & $\mathrm{~N}$ & 4 & 461.2 & 231.1 \\
\hline 1319.5 & 2638.1 & 21 & $\mathrm{D}$ & 3 & 347.2 & 174.1 \\
\hline 1348.0 & 2695.1 & 22 & $\mathrm{G}$ & 2 & 232.1 & 116.6 \\
\hline & & 23 & $\mathrm{R}$ & 1 & 175.1 & 88.1 \\
\hline
\end{tabular}




\section{Characterization of labelled protein conjugates by circular dichroism}

Circular dichroism spectra of 2 and $2 a$

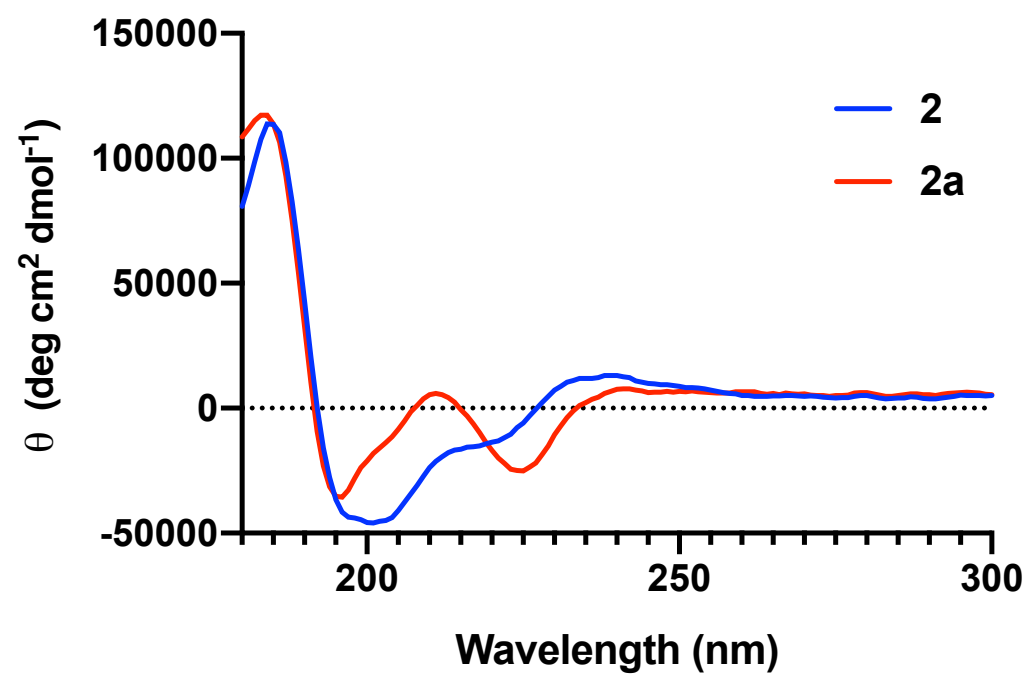

Figure 14. Circular dichroism of unmodified 2 (water, blue line) and 2a (water, red line). Circular dichroism spectra of 3 and $3 a$

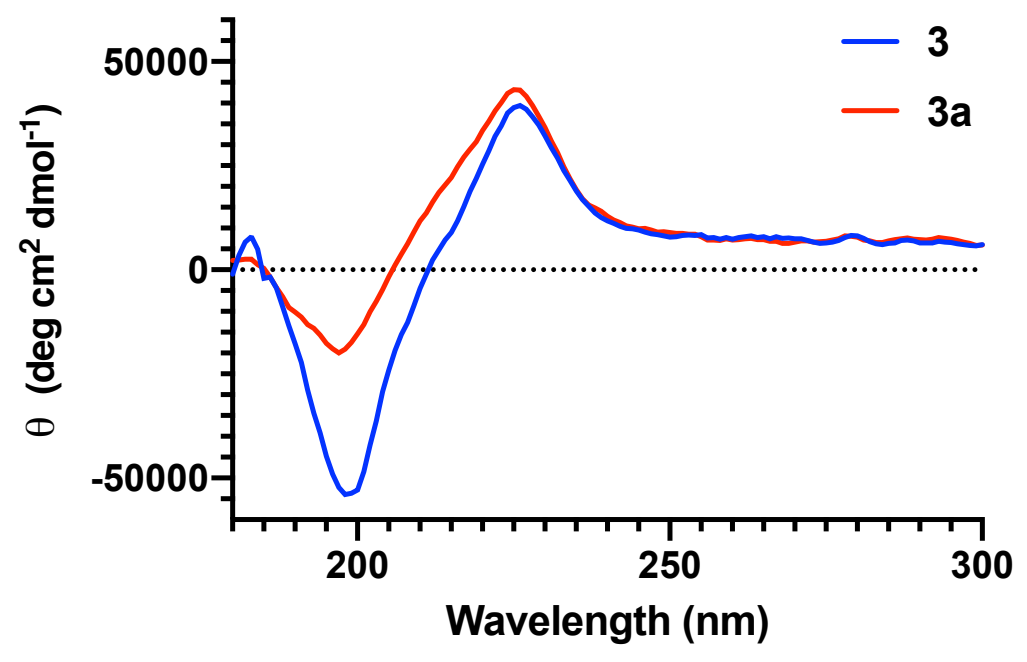

Figure 15. Circular dichroism of unmodified $\mathbf{3}$ (water, blue line) and $\mathbf{3 a}$ (water, red line). 


\section{Circular dichroism of 4 and conjugate $4 a$}

A sufficient quantity of conjugate $\mathbf{4 a}$ was isolated via HPLC method $\mathrm{C}$ from multiple reactions of for acquisition of a CD spectrum using the following conditions: Labeling of daptomycin with salt 1 a was performed using daptomycin $(4)(20 \mu \mathrm{L}, 0.74 \mathrm{mM}, 25 \mu \mathrm{M}$ final concentration), $1 \mathrm{a}(168 \mu \mathrm{L}$, $25 \mathrm{mM}, 7 \mathrm{mM}$ final concentration), $\mathrm{NH}_{4} \mathrm{OAc}(120 \mu \mathrm{L}, 100 \mathrm{mM}, \mathrm{pH} 6.9,20 \mathrm{mM}$ final concentration), glutathione $(60 \mu \mathrm{L}, 10 \mathrm{mM}, 1 \mathrm{mM}$ final concentration) and water $(232 \mu \mathrm{L})$ with a 60 minute irradiation time. The concentration of the conjugate was estimated by UV-Vis at $364 \mathrm{~nm}$, correlating to kynurenine absorption.

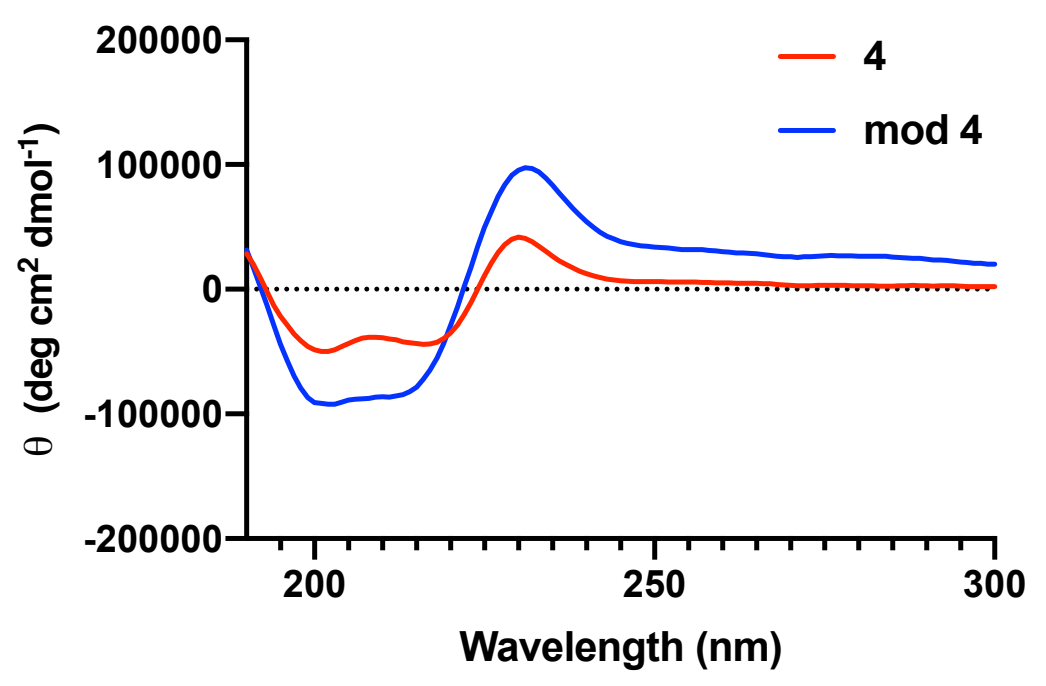

Figure 15A. (A) Circular dichroism of 4 (water, red line) and conjugate 4a (water, blue line). 
NMR characterization of a Octreotide conjugate $2 a$ and Leuprolide conjugate $3 a$.

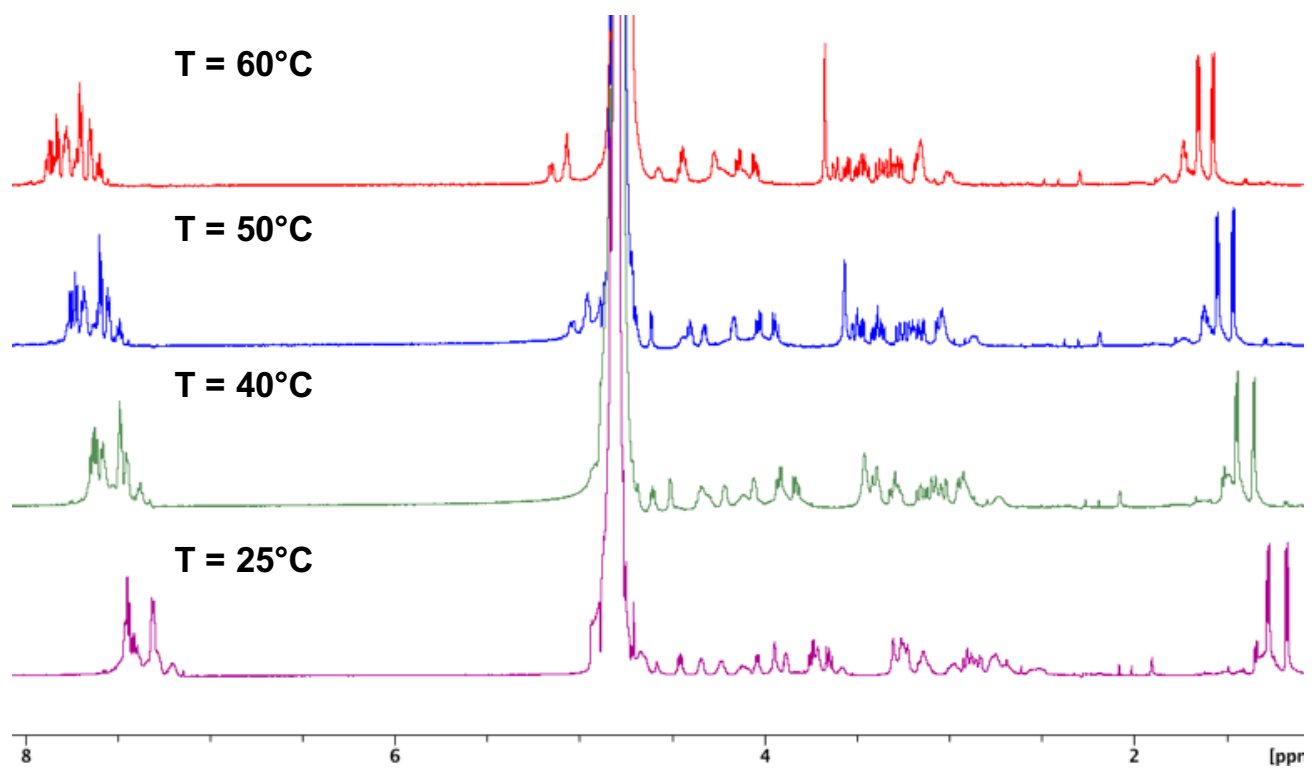

Figure 16. Variable temperature ${ }^{1} \mathrm{H}-\mathrm{NMR}$ studies of $2 \mathrm{a}$ in $20 \mathrm{mM}$ ammonium acetate- $\mathrm{D}_{7}$ buffered $\mathrm{D}_{2} \mathrm{O}$. The sample was acquired at $600 \mathrm{MHz}$ using a Shigemi NMR tube matched to $\mathrm{D}_{2} \mathrm{O}$. 


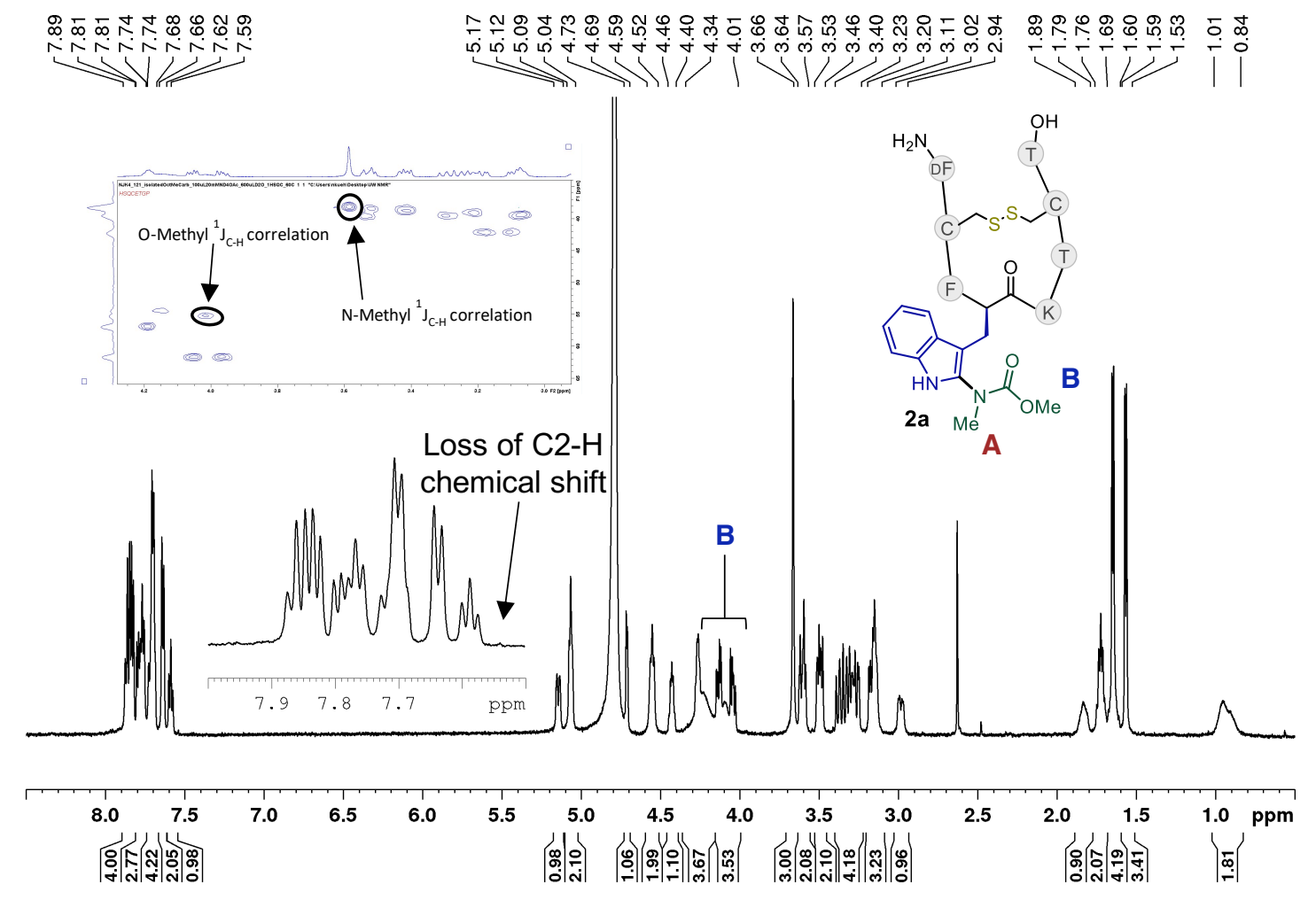

Figure 16A. ${ }^{1} \mathrm{H}-\mathrm{NMR}$ of $2 \mathrm{a}$ at $60^{\circ} \mathrm{C}$ in $20 \mathrm{mM}$ ammonium acetate- $\mathrm{D}_{7}$ buffered $\mathrm{D}_{2} \mathrm{O}$. The singlet at $3.64 \mathrm{ppm}$ is assigned as the $\mathrm{N}$-methyl group (labelled as A) of the transferring carbamate based upon an HSQC (see inset) ${ }^{1} \mathrm{~J}_{\mathrm{C}-\mathrm{H}}$ correlation with a carbon chemical shift at $38.1 \mathrm{ppm}$. The $\mathrm{O}-$ methyl group of the transferring carbamate is assigned as a broad peak lying within the multiple overlapping signals between 4.01-4.34 ppm. This assignment is reinforced by the appearance of a ${ }^{1} \mathrm{~J}_{\mathrm{C}-\mathrm{H}}$ correlation between this broad peak at a ${ }^{13} \mathrm{C}$ chemical shift at $55.2 \mathrm{ppm}$. The broadening of these peak is likely due to hindered rotation within the carbamate moiety (see figure $\mathrm{XX}$, the one above, for reference). 
A)
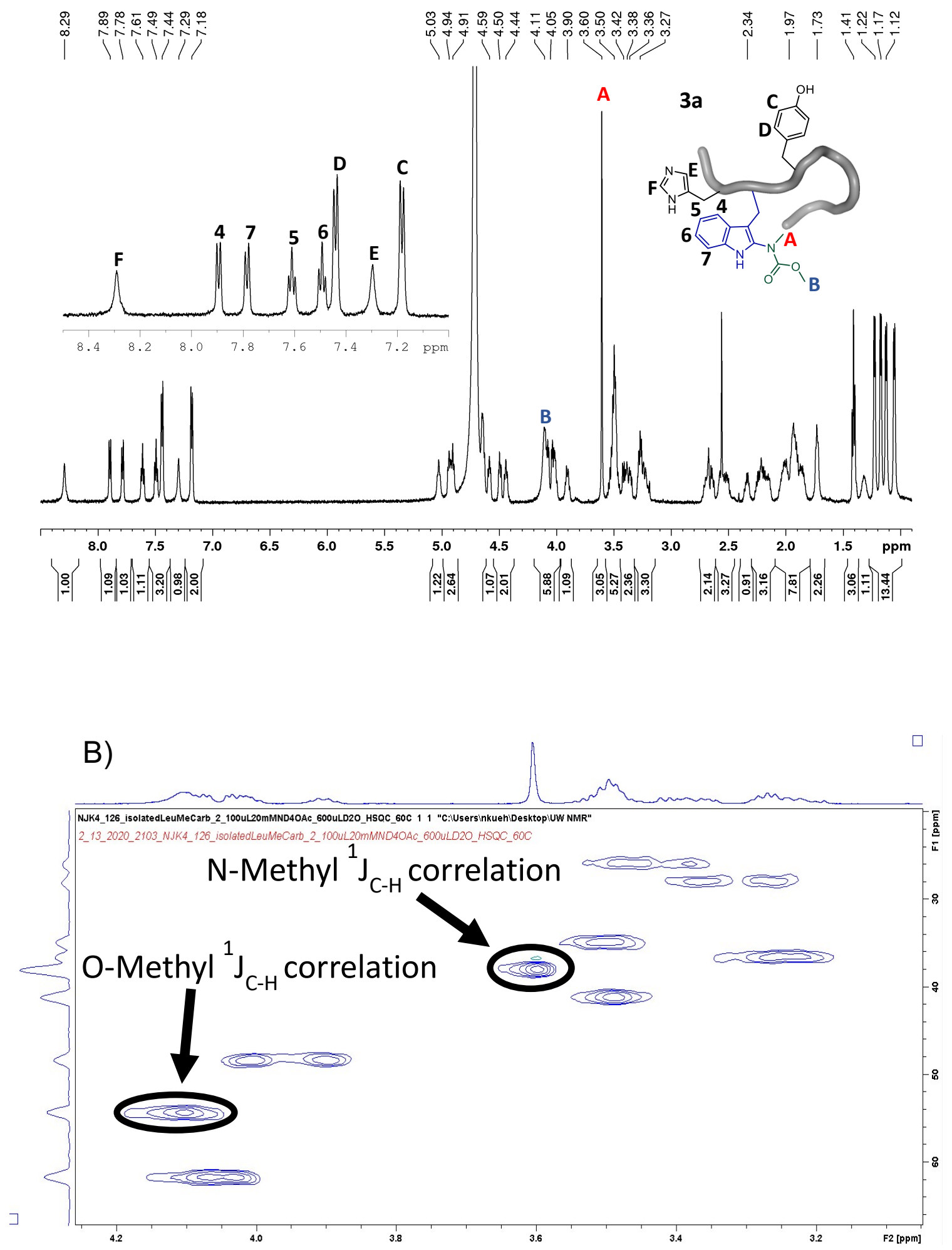
C)

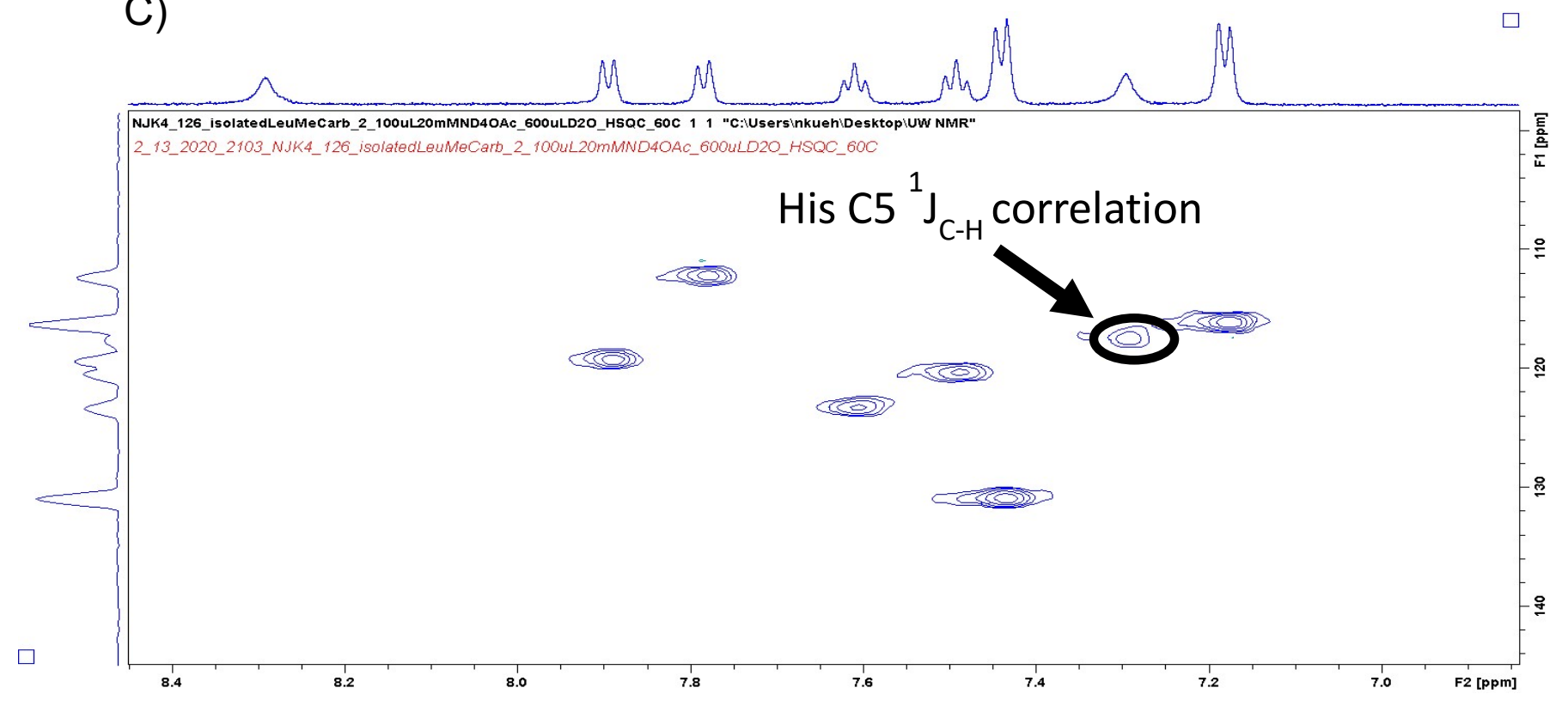

Figure 16B. A) ${ }^{1} \mathrm{H}-\mathrm{NMR}$ of $3 \mathrm{a}$ at $60^{\circ} \mathrm{C}$ in $20 \mathrm{mM}$ ammonium acetate- $\mathrm{D}_{7}$ buffered $\mathrm{D}_{2} \mathrm{O}$. The singlet at $3.6 \mathrm{ppm}$ (labelled as A) is assigned as the $\mathrm{N}$-methyl group of the transferring carbamate based upon an HSQC (see B) ) ${ }^{1} \mathrm{~J}_{\mathrm{C}-\mathrm{H}}$ correlation with a carbon chemical shift at $38.1 \mathrm{ppm}$. B) HSQC data for $3 \mathbf{a}$ at $60{ }^{\circ} \mathrm{C}$ in $20 \mathrm{mM}$ ammonium acetate- $\mathrm{D}_{7}$ buffered $\mathrm{D}_{2} \mathrm{O}$. The O-methyl group of the transferring carbamate is assigned as broad peaks lying within the multiple signals between 4.18$4.02 \mathrm{ppm}$. This assignment is reinforced by the appearance of a ${ }^{1} \mathrm{~J}_{\mathrm{C}-\mathrm{H}}$ correlation between this broad peak at a ${ }^{13} \mathrm{C}$ chemical shift at $54.3 \mathrm{ppm}$. The broadening of these peak is likely due to hindered rotation within the carbamate moiety. C) HSQC data for aromatic region of $3 a$ at $60{ }^{\circ} \mathrm{C}$ in $20 \mathrm{mM}$ ammonium acetate- $\mathrm{D}_{7}$ buffered $\mathrm{D}_{2} \mathrm{O}$. 


\section{Mechanistic Studies}

\section{Labeling of Octreotide with pyridinium salt 1a in presence of Nal}

Labeling of octreotide with salt 1a was performed using $2(38 \mu \mathrm{L}, 790 \mu \mathrm{M}, 100 \mu \mathrm{M}$ final concentration), $1 \mathrm{a}\left(21 \mu \mathrm{L}, 100 \mathrm{mM}, 7 \mathrm{mM}\right.$ final concentration), $\mathrm{NH}_{4} \mathrm{OAc}(3 \mu \mathrm{L}, 2 \mathrm{M}, \mathrm{pH} 6.9,20$ $\mathrm{mM}$ final concentration), glutathione $(3 \mu \mathrm{L}, 100 \mathrm{mM}, 1 \mathrm{mM}$ final concentration), Nal $(21 \mu \mathrm{L}, 100$ $\mathrm{mM}, 7 \mathrm{mM}$ final concentration) and water $(214 \mu \mathrm{L})$ with a 30 minute irradiation time. The reaction was directly analyzed via LC/MS method $B$ and was judged to have proceeded in $6 \%$ conversion to $2 \mathbf{a}$.

\section{Labeling of Octreotide with pyridinium salt 1a in the presence of 3-methyl-2-buten-1-ol}

Labeling of octreotide was performed using $2(13 \mu \mathrm{L}, 2.4 \mathrm{mM}, 100 \mu \mathrm{M}$ final concentration), 1a $\left(21 \mu \mathrm{L}, 100 \mathrm{mM}, 7 \mathrm{mM}\right.$ final concentration), $\mathrm{NH}_{4} \mathrm{OAc}(4 \mu \mathrm{L}, 1.6 \mathrm{M}, \mathrm{pH} 6.9,20 \mathrm{mM}$ final concentration), glutathione (3 $\mu \mathrm{L}, 100 \mathrm{mM}, 1 \mathrm{mM}$ final concentration), 3-methyl-2-buten-1-ol $(42 \mu \mathrm{L}, 50 \mathrm{mM}, 7 \mathrm{mM}$ final concentration) and water $(217 \mu \mathrm{L})$ with a 30 minute irradiation time. The reaction was directly analyzed via LC/MS method $B, C$ and $D$, and was judged to have proceeded with $>95 \%$ conversion, $>20: 1$ mono:di labelled ratio.

A similar reaction with $2(13 \mu \mathrm{L}, 2.4 \mathrm{mM}, 100 \mu \mathrm{M}$ final concentration), $1 \mathrm{a}(21 \mu \mathrm{L}, 100 \mathrm{mM}, 7 \mathrm{mM}$ final concentration), $\mathrm{NH}_{4} \mathrm{OAc}(4 \mu \mathrm{L}, 1.6 \mathrm{M}, \mathrm{pH} 6.9,20 \mathrm{mM}$ final concentration), glutathione $(3 \mu \mathrm{L}$, $100 \mathrm{mM}, 1 \mathrm{mM}$ final concentration), 3-methyl-2-buten-1-ol $(120 \mu \mathrm{L}, 50 \mathrm{mM}, 20 \mathrm{mM}$ final concentration) and water $(139 \mu \mathrm{L})$ proceeded with a $>95 \%$ conversion, $>20: 1$ mono:di labelled ratio.

\section{Labeling of Octreotide with pyridinium salt 1a in the presence of TEMPO}

Labeling of octreotide was performed 2 (38 $\mu \mathrm{L}, 790 \mu \mathrm{M}, 100 \mu \mathrm{M}$ final concentration), salt 1a (21 $\mu \mathrm{L}, 100 \mathrm{mM}, 7 \mathrm{mM}$ final concentration), $\mathrm{NH}_{4} \mathrm{Cl}(3 \mu \mathrm{L}, 2 \mathrm{M}, \mathrm{pH}$ 6.9, $20 \mathrm{mM}$ final concentration), glutathione $(3 \mu \mathrm{L}, 100 \mathrm{mM}, 1 \mathrm{mM}$ final concentration), TEMPO $(21 \mu \mathrm{L}, 100 \mathrm{mM}, 7 \mathrm{mM}$ final concentration) and water $(214 \mu \mathrm{L})$ with a 30 minute irradiation time. The reaction was directly analyzed via LC/MS method B, C and D, and was judged to have proceeded with $22 \%$ conversion, $10 \%$ label, $>20: 1$ mono:di labelled ratio.

A similar reaction with $2(38.2 \mu \mathrm{L}, 790 \mu \mathrm{M}, 100 \mu \mathrm{M}$ final concentration), salt 1a $(21 \mu \mathrm{L}, 100 \mathrm{mM}$, $7 \mathrm{mM}$ final concentration), $\mathrm{NH}_{4} \mathrm{Cl}(3 \mu \mathrm{L}, 2 \mathrm{M}, \mathrm{pH} 6.9,20 \mathrm{mM}$ final concentration), glutathione (3 $\mu \mathrm{L}, 100 \mathrm{mM}, 1 \mathrm{mM}$ final concentration), TEMPO $(100 \mu \mathrm{L}, 100 \mathrm{mM}, 33 \mathrm{mM}$ final concentration) and water $(135 \mu \mathrm{L})$ proceeded in $34 \%$ conversion, $8 \% 2 \mathrm{a},>20: 1$ mono:di labelled ratio. 


\section{dl-Tryptophan Deuterium Exchange}

Deuterium exchange of dl-tryptophan was performed using dl-tryptophan $(600 \mu \mathrm{L}, 5 \mathrm{mM}$ stock solution in $\mathrm{D}_{2} \mathrm{O}, 5 \mathrm{mM}$ final concentration). The reaction mixture was irradiated for 90 minutes, and then the reaction was analyzed by ${ }^{1} \mathrm{H}-\mathrm{NMR}$. $>95 \%$ deuterium incorporation was observed exclusively at the C-4 position (Figure 14, B). A control sample left under ambient conditions showed no deuterium incorporation after 90 minutes (Figure 14, A).

A similar experiment was performed using dl-tryptophan $\left(600 \mu \mathrm{L}, 5 \mathrm{mM}\right.$ stock solution in $\mathrm{D}_{2} \mathrm{O}, 5$ $\mathrm{mM}$ final concentration) and a $311 \mathrm{~nm}$ light source (Philips PI-S 9W/01 9-watt lamp). The reaction mixture was irradiated for 90 minutes, and then the reaction was analyzed by ${ }^{1} \mathrm{H}-\mathrm{NMR}$. $75 \%$ deuterium incorporation was observed at the C-4 position after 90 minutes (Figure 14, C).

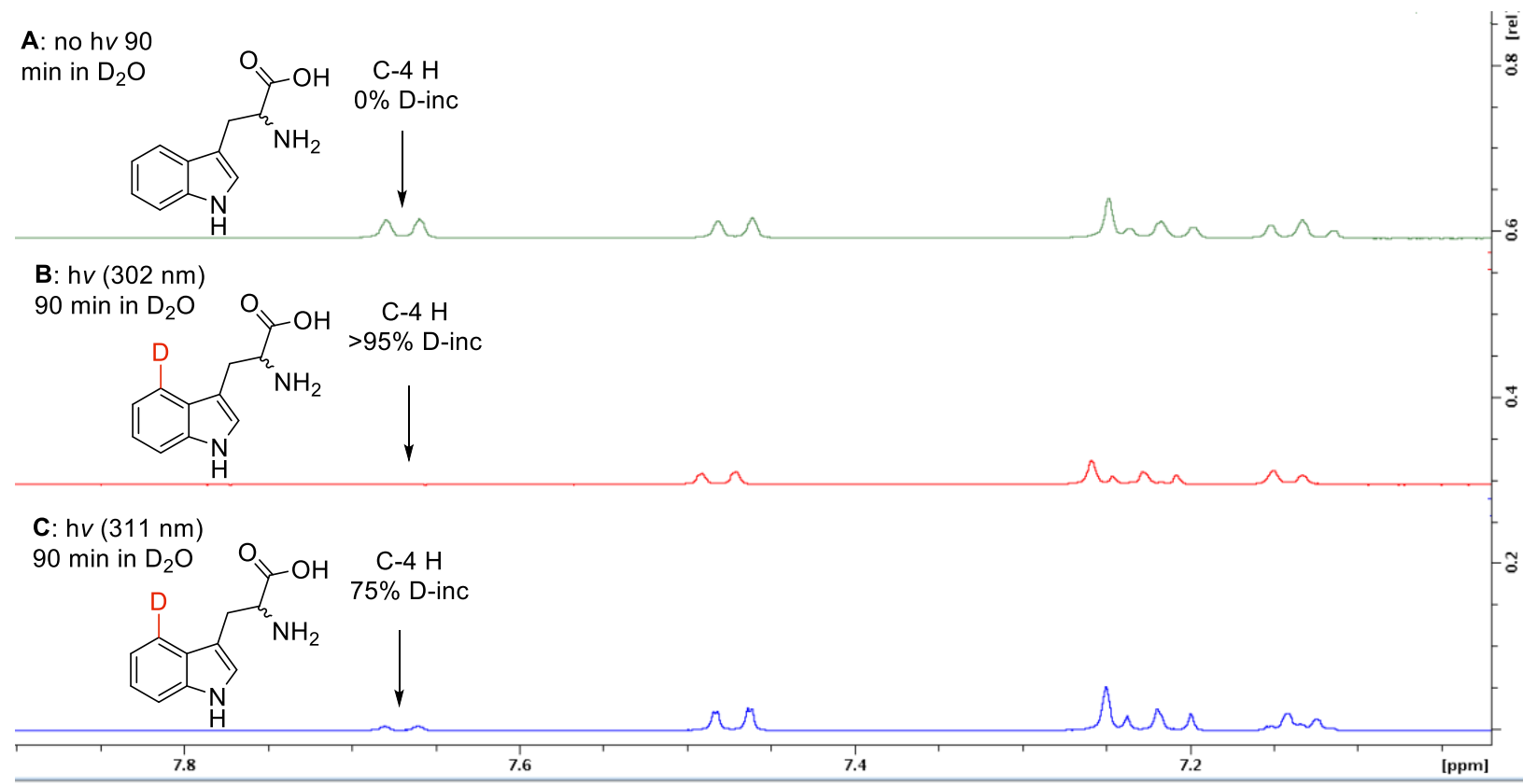

Figure 17. A. ${ }^{1} \mathrm{H}-\mathrm{NMR}$ spectrum of $5 \mathrm{mM}$ dl-tryptophan after 90 minutes in $\mathrm{D}_{2} \mathrm{O}$ and various $\mathrm{UV}$ exposure. 
Labeling of Octreotide with pyridinium salt 1a using $305 \mathrm{~nm}$ and $320 \mathrm{~nm}$ long-pass filters Labelling experiments involving filtered light or alternative lamp sources were performed using either general procedures $A$ or $\mathrm{C}$ using $100 \mu \mathrm{M} \mathrm{2,1} \mathrm{mM}, \mathrm{GSH}, 7 \mathrm{mM}$ 1a and $20 \mathrm{mM} \mathrm{NH}_{4} \mathrm{OAc}$ buffer. Results are summarized in Table 1 and are the average of two experiments:

\section{Labeling of octreotide with pyridinium salt 1a using a $311 \mathrm{~nm}$ light source}

Labeling of octreotide acetate with a $311 \mathrm{~nm}$ lamp (Philips PI-S 9W/01 9W) was performed using 2 (34 $\mu \mathrm{L}, 0.88 \mathrm{mM}, 100 \mu \mathrm{M}$ final concentration), $1 \mathrm{a}(60 \mu \mathrm{L}, 35 \mathrm{mM}, 7 \mathrm{mM}$ final concentration), $\mathrm{NH}_{4} \mathrm{OAc}(60 \mu \mathrm{L}, 100 \mathrm{mM}, \mathrm{pH} 6.9,20 \mathrm{mM}$ final concentration), glutathione (60 $\mu \mathrm{L}$, $5 \mathrm{mM}, 1 \mathrm{mM}$ final concentration) and water $(86 \mu \mathrm{L})$ with an irradiation time of 120 minutes. The reaction mixture was directly analyzed via LC/MS method $B$ and was judged to have proceeded with $>95 \%$ conversion, $>20: 1$ mono:di labelled.

A replicate reaction using 2 (34 $\mu \mathrm{L}, 0.88 \mathrm{mM}, 100 \mu \mathrm{M}$ final concentration), $1 \mathrm{a}$ (60 $\mu \mathrm{L}, 35 \mathrm{mM}, 7$ $\mathrm{mM}$ final concentration), $\mathrm{NH}_{4} \mathrm{OAc}(60 \mu \mathrm{L}, 100 \mathrm{mM}, \mathrm{pH} 6.9,20 \mathrm{mM}$ final concentration), glutathione $(60 \mu \mathrm{L}, 5 \mathrm{mM}, 1 \mathrm{mM}$ final concentration) and water $(86 \mu \mathrm{L})$ proceeded with a $>95 \%$ conversion, $>20: 1$ mono:di labelled.

\section{Labeling of octreotide with pyridinium salt 1a using a $365 \mathrm{~nm}$ light source}

Labeling of octreotide acetate with a $365 \mathrm{~nm}$ lamp (Analytikjena, UVP 3UV Lamp, $8 \mathrm{~W}$ ) was performed using 2 ( $3 \mu \mathrm{L}, 10.7 \mathrm{mM}, 100 \mu \mathrm{M}$ final concentration), $1 \mathrm{a}(21 \mu \mathrm{L}, 100 \mathrm{mM}, 7 \mathrm{mM}$ final concentration), $\mathrm{NH}_{4} \mathrm{OAc}(3 \mu \mathrm{L}, 2 \mathrm{M}, \mathrm{pH} 6.9,20 \mathrm{mM}$ final concentration), glutathione (3 $\mu \mathrm{L}, 100$ $\mathrm{mM}, 1 \mathrm{mM}$ final concentration) and water $(270 \mu \mathrm{L})$ with an irradiation time of 30 minutes. The reaction mixture was directly analyzed via LC/MS method $B$ and was judged to have proceeded with $0 \%$ conversion.

A replicate reaction using 2 ( $3 \mu \mathrm{L}, 10.7 \mathrm{mM}, 100 \mu \mathrm{M}$ final concentration), 1a (21 $\mu \mathrm{L}, 100 \mathrm{mM}, 7$ $\mathrm{mM}$ final concentration), $\mathrm{NH}_{4} \mathrm{OAc}(3 \mu \mathrm{L}, 2 \mathrm{M}, \mathrm{pH} 6.9,20 \mathrm{mM}$ final concentration), glutathione (3 $\mu \mathrm{L}, 100 \mathrm{mM}, 1 \mathrm{mM}$ final concentration) and water $(270 \mu \mathrm{L})$ proceeded with $0 \%$ conversion.

\begin{tabular}{llll}
$\begin{array}{l}\text { Filter/ } \\
\text { wavelength }\end{array}$ & Time & \% conversion & $\%$ 2a \\
\hline $305 \mathrm{~nm}$ & 30 minutes & $22 \%$ & $19 \%$ \\
$305 \mathrm{~nm}$ & 120 minutes & $>95 \%$ & $95 \%$ \\
$320 \mathrm{~nm}$ & 30 minutes & $0 \%$ & $0 \%$ \\
$311 \mathrm{~nm}$ & 120 minutes & $>95 \%$ & $95 \%$ \\
$365 \mathrm{~nm}$ & 30 minutes & $0 \%$ & $0 \%$
\end{tabular}

Table 1. Conversions from $305 \mathrm{~nm}$ long-pass filter and $320 \mathrm{~nm}$ long-pass filter, and from a 311 $\mathrm{nm}$ light source and a $365 \mathrm{~nm}$ light source; estimated by TIC. 


\section{Temporal Control Experiments:}

Labeling of octreotide acetate was performed using $2(114 \mu \mathrm{L}, 880 \mu \mathrm{M}, 100 \mu \mathrm{M}$ final concentration), $1 \mathrm{a}\left(140 \mu \mathrm{L}, 50 \mathrm{mM}, 7 \mathrm{mM}\right.$ final concentration), $\mathrm{NH}_{4} \mathrm{OAc}(13 \mu \mathrm{L}, 1.6 \mathrm{M}, 20 \mathrm{mM}$ final concentration), glutathione (10 $\mu \mathrm{L}, 100 \mathrm{mM}, 1 \mathrm{mM}$ final concentration) and water $(723 \mu \mathrm{L})$. The irradiation time points proceeded as follows: 0-5 min, lamp on; 5-10 min; lamp off, 10-15 min, lamp on; 15-20 min, lamp off; 20-25 min, lamp on; 25-30 min, lamp off; 30-35 min, lamp on; 3540 min, lamp off; 40-45 min, lamp on; 45-50 min, lamp off; 50-55 min, lamp on; 55-60 min, lamp off. A $15 \mu \mathrm{L}$ aliquot was taken every 5 minutes. The reaction was run with a $1 \mathrm{~mL}$ total volume so that aliquot removal would not significantly alter reaction rates. The reaction was performed in duplicate and the average conversions are plotted in figure 18:

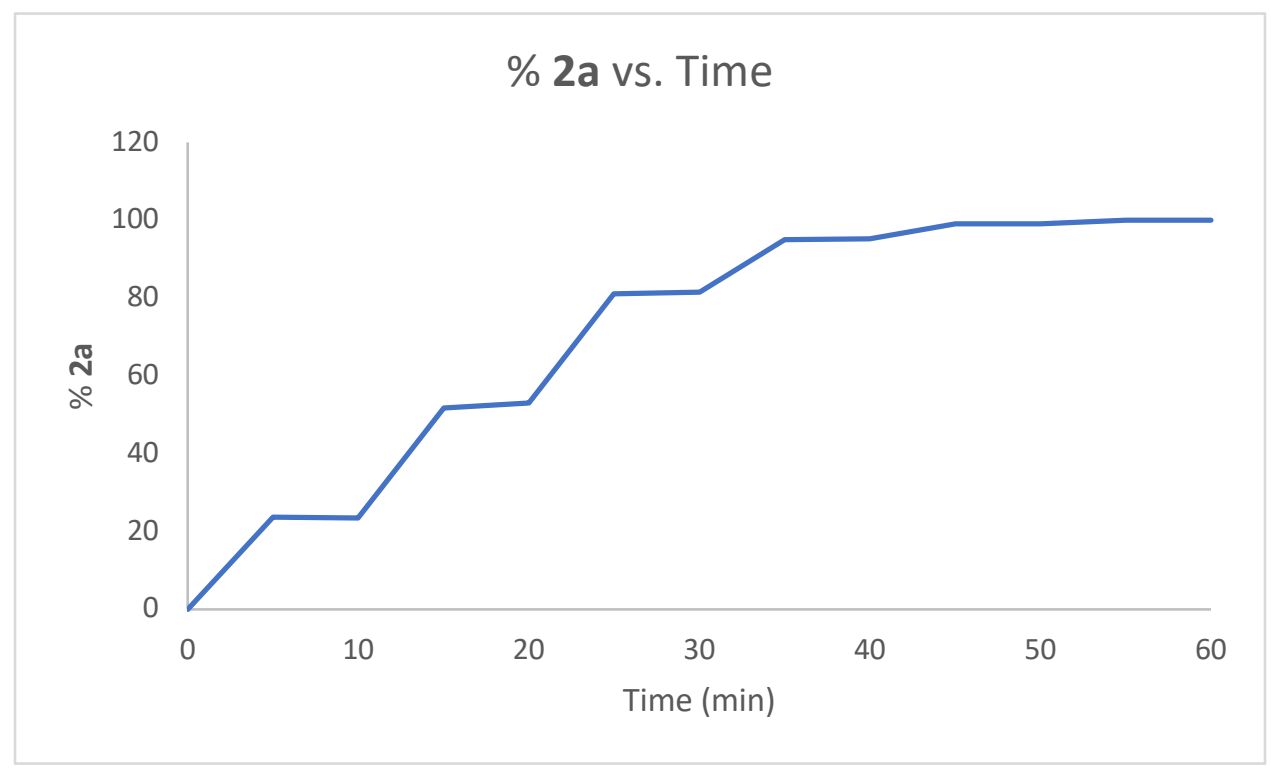

Figure 18. \%2a versus time. 


\section{Cyclic Voltammetry Data of 1a and 1d}

Cyclic Voltammetry was performed out using an EC potentiostat from BASi with a platinum electrode as the working, $\mathrm{Ag} / \mathrm{AgCl}$ as reference, and platinum wire as the counter electrodes. $\mathrm{CV}$ data were acquired in $\mathrm{CH}_{3} \mathrm{CN}$ using $40 \mathrm{mM}$ of the pyridinium salt and $100 \mathrm{mM} \mathrm{Bu}_{4} \mathrm{NPF}_{6}$ as the electrolyte.

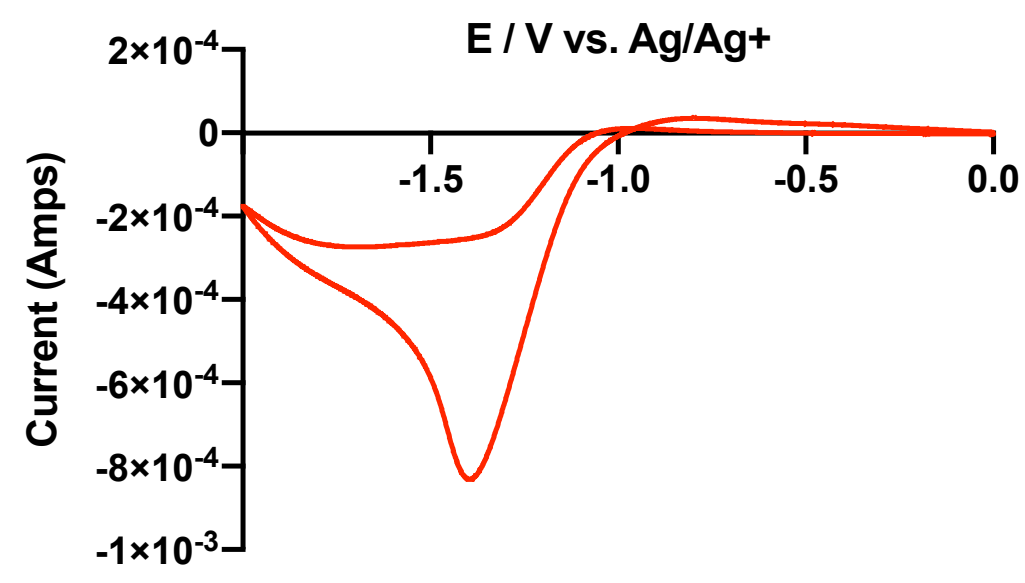

Figure 19. Cyclic Voltammetry data for 1a

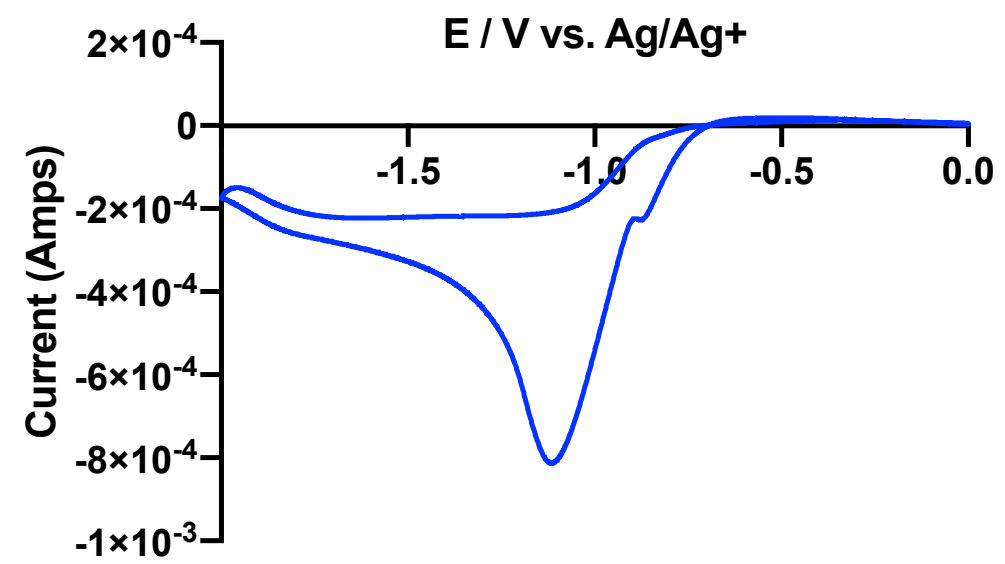

Figure 20. Cyclic Voltammetry data for 1d 


\section{Absorption spectra of $1 \mathrm{a}$ in $\mathrm{pH} 6.9 \mathrm{NH}_{4}$ OAc:}
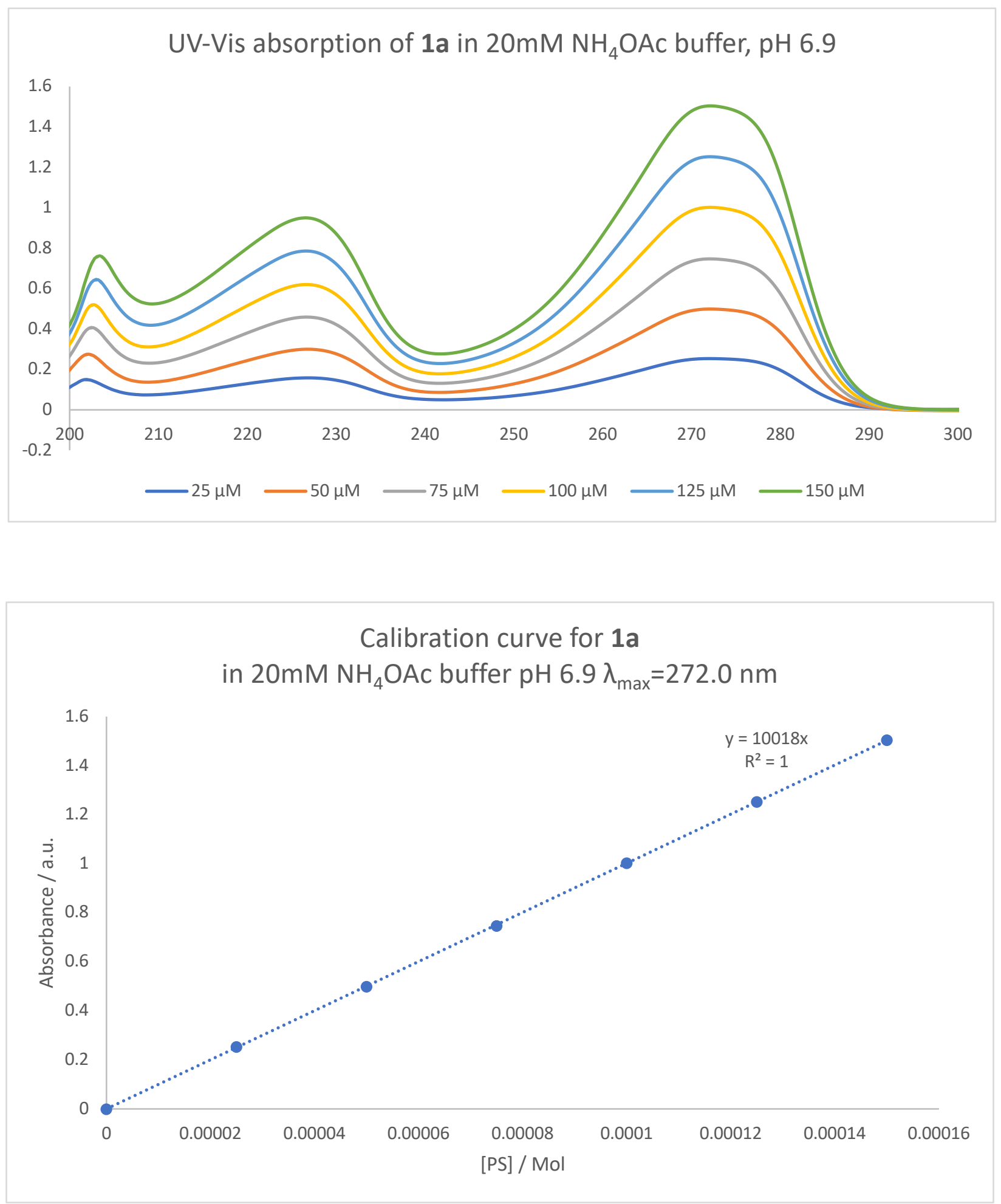
Absorption spectra of 1d in $\mathrm{pH} 6.9 \mathrm{NH}_{4}$ OAc:
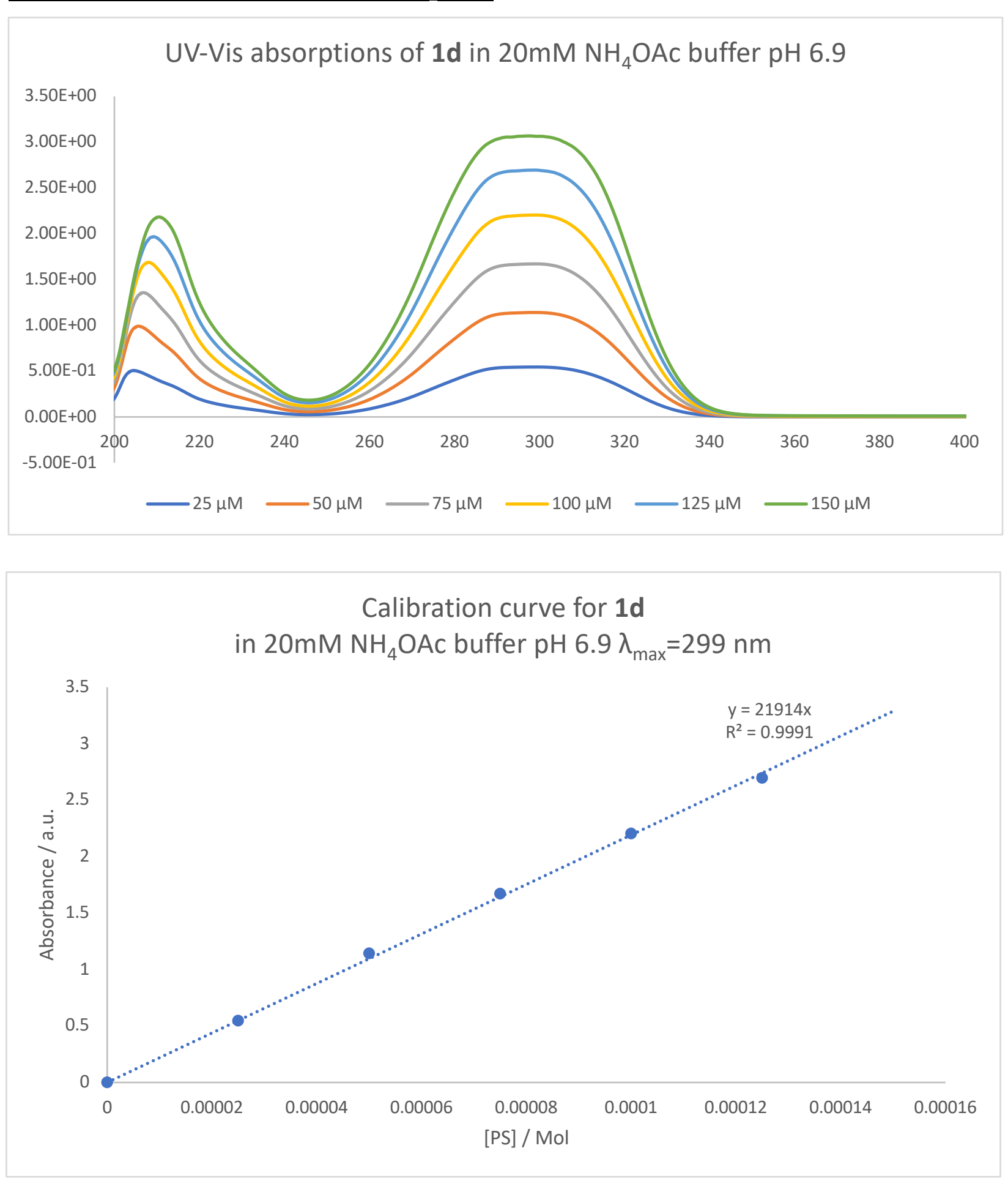


\section{Stern-Volmer analysis of 2 with $1 \mathrm{a}$}

Stern Volmer plots were generated by excitation of a $15 \mu \mathrm{M}$ solution of 2 in degassed $20 \mathrm{mM} \mathrm{pH}$ $6.9 \mathrm{NH}_{4} \mathrm{OAc}$ buffer in the presence of increasing concentrations of 1a. Analyses were performed at 280 and $295 \mathrm{~nm}$ excitation:
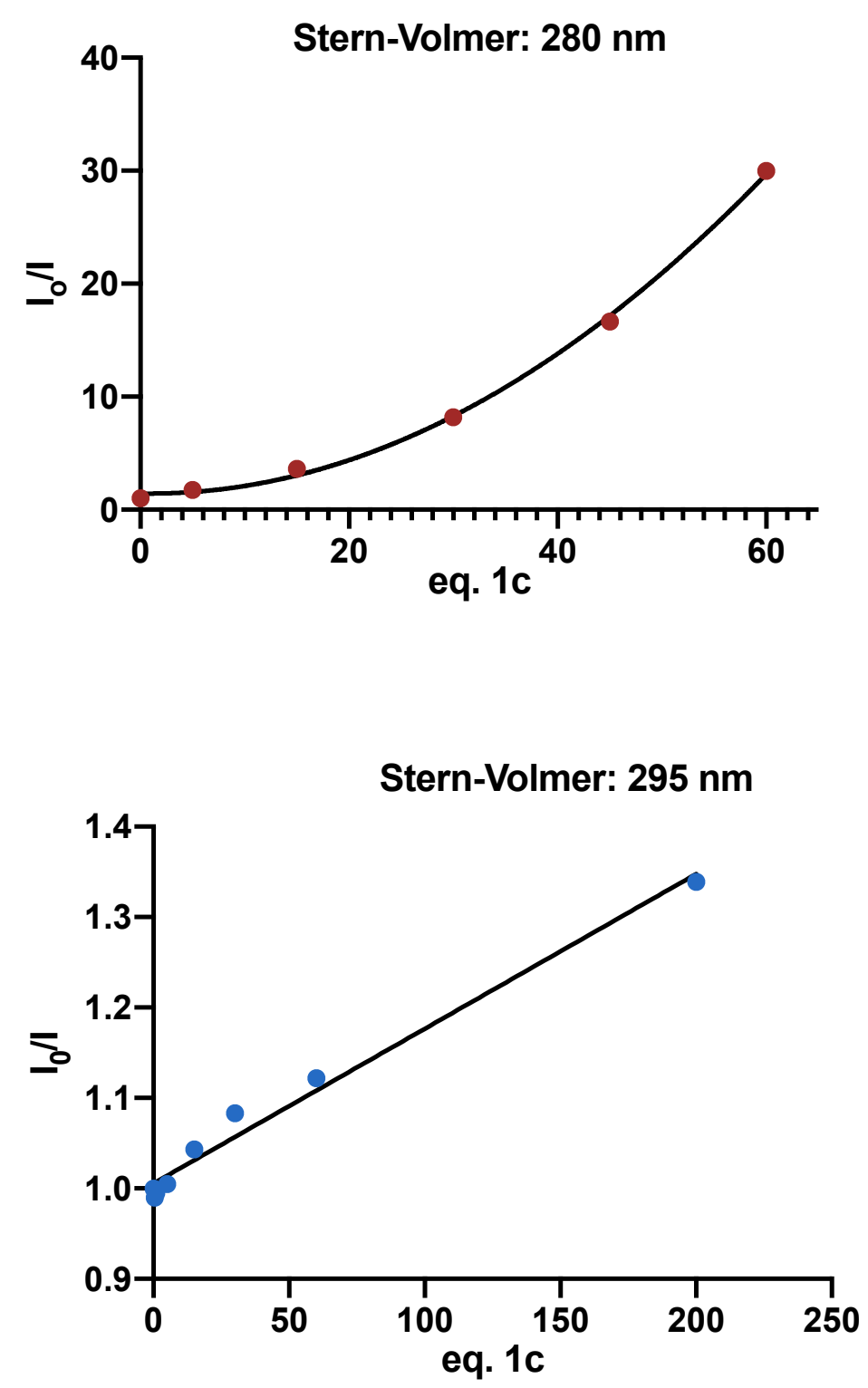

Figure 21. Stern Volmer plots between 2 and $1 \mathrm{a}$. 


\section{Reaction Quantum Yield of the labelling of 2 with 1a using $311 \mathrm{~nm}$ narrowband emission}

light.

Potassium ferrioxalate was prepared under red safelight according to literature precedent ${ }^{13}$. Actinometry was performed using the following solutions:

Solution A: $600 \mu \mathrm{M} \mathrm{2,7mM} \mathrm{1a,} 20 \mathrm{mM} \mathrm{NH}_{4} \mathrm{OAC}, 1 \mathrm{mM} \mathrm{GSH}$. $800 \mu \mathrm{L}$ reaction volume

Solution B: $0 \mathrm{mM}$ 2, $7 \mathrm{mM}$ 1a, $20 \mathrm{mM} \mathrm{NH}_{4} \mathrm{OAC}, 1 \mathrm{mM} \mathrm{GSH}$. $800 \mu \mathrm{L}$ reaction volume

Actinometer solution: $0.15 \mathrm{M} \mathrm{KFeC}_{2} \mathrm{O}_{4}$ in $0.10 \mathrm{~N} \mathrm{H}_{2} \mathrm{SO}_{4}$. $800 \mu \mathrm{L}$ reaction volume

Chemical actinometry was performed as follows:

Irradiation in the presence of 2:

Using a dual cuvette holder, the actinometer solution was placed $5.0 \mathrm{~cm}$ from the lamp in line with solution A ( $3.4 \mathrm{~cm}$ from lamp) such that light emissions from the lamp pass through the labelling solution before reaching the actinometer. Each solution was placed in a quartz cuvette (pathlength: $1 \mathrm{~cm}$ volume: $0.80 \mathrm{~mL}$ ), sparged with argon for 20 minutes, and irradiated with a $311 \mathrm{~nm}$ narrow band light-source (Philips PI-S 9W/01 9W, $6 \mathrm{~nm}$ FWHM) for 15 minutes. Formation of $\mathbf{2 a}$ was kept to below $15 \%$ in order to minimize error due to absorbance overlap between 2 and 2a. In order to ensure that the entirety of the lamp emissions were absorbed by the actinometer, the procedure was performed using an actinometer solution with $\left[\mathrm{KFeC}_{2} \mathrm{O}_{4}\right]=6 \mathrm{mM}$, giving similar quantum yields.

Irradiation in the absence of 2:

Using a dual cuvette holder, the actinometer solution was placed in line with solution B such that light emissions from the lamp pass through the labelling solution before reaching the actinometer. Each solution was placed in a quartz cuvette (pathlength: $1 \mathrm{~cm}$ volume: $0.80 \mathrm{~mL}$ ), sparged with argon for 20 minutes, and irradiated with a 311nm narrow band lightsource (Philips PI-S 9W/01 9W, $6 \mathrm{~nm}$ FWHM) for 15 minutes.

\section{Actinometer Development:}

Following irradiation, $0.50 \mathrm{ml}$ of the actinometer was diluted with $0.25 \mathrm{~mL}$ of a mixed buffer solution of sodium acetate $(0.6 \mathrm{M})$ and $\mathrm{H}_{2} \mathrm{SO}_{4}(0.36 \mathrm{~N})$ and $4.25 \mathrm{~mL}$ water. This mixture $(1.00 \mathrm{~mL})$ was diluted once again by 1,10 -phenanthroline $(1.00 \mathrm{~mL}, 50 \mathrm{mM})$, and water $(8.00 \mathrm{~mL})$. The resultant solution was developed $30 \mathrm{~min}$ in the dark. The absorbance at $510 \mathrm{~nm}$ was measured, and this process repeated with water replacing the volume of octreotide acetate in the reaction cuvette.

Determination of the quantum yield:

The absorbance at $510 \mathrm{~nm}$ was converted to a quantity of ferrous ion produced in the full actinometer solution using the above calibration, and then to an irradiative number of photons using a quantum yield of $1.24^{14}$. The conversion of octreotide was converted to a molar value and divided by . The difference in photon count between the actinometer solutions (measured against solutions $A$ and $B$ ) to provide a quantum yield estimation of $0.082 \pm 0.021(n=4)$.

\begin{tabular}{|c|c|c|c|c|c|}
\hline Trial & $\begin{array}{c}\text { Moles Fe } \\
\text { from soln A }\end{array}$ & $\begin{array}{c}\text { Moles Fe } \\
\text { from soln B }\end{array}$ & $\begin{array}{c}\text { Einsteins } \\
\text { absorbed by 2 }\end{array}$ & $\begin{array}{c}\text { Moles 2a } \\
\text { formed }\end{array}$ & Quantum Yield \\
\hline 1 & $3.37 \times 10^{-6}$ & $4.07 \times 10^{-6}$ & $5.64 \times 10^{-7}$ & $4.94 \times 10^{-8}$ & 0.088 \\
\hline 2 & $3.28 \times 10^{-6}$ & $4.28 \times 10^{-6}$ & $8.10 \times 10^{-7}$ & $4.42 \times 10^{-8}$ & 0.055 \\
\hline 3 & $3.65 \times 10^{-6}$ & $4.17 \times 10^{-6}$ & $4.25 \times 10^{-7}$ & $4.80 \times 10^{-8}$ & 0.113 \\
\hline 4 & $3.41 \times 10^{-6}$ & $4.25 \times 10^{-6}$ & $6.79 \times 10^{-7}$ & $4.94 \times 10^{-8}$ & 0.073 \\
\hline
\end{tabular}




\section{Stability Studies of 1a}

Pyridinium Salt 1a (100 mM in $\mathrm{D}_{2} \mathrm{O}, 7 \mathrm{mM}$ final concentration) was monitored via ${ }^{1} \mathrm{H}-\mathrm{NMR}$ for a minimum of 48 hours. The aromatic proton shift in 1a was monitored using the aromatic $\mathrm{C}-\mathrm{H}$ peak of DMF $(7 \mathrm{mM})$ as an internal standard $\delta: 7.92(\mathrm{~s}, 1 \mathrm{H})$. Samples were maintained at room temperature over the duration of the study.

Stability Study A

1a $\left(7 \mathrm{mM}\right.$ in $\left.\mathrm{D}_{2} \mathrm{O}\right)$ and DMF $\left(7 \mathrm{mM}\right.$ in $\left.\mathrm{D}_{2} \mathrm{O}\right)$ were monitored over 49 hours via ${ }^{1} \mathrm{H}-\mathrm{NMR}$.

\section{$\%$ Salt 1a Over Time \\ $\ln \mathrm{D}_{2} \mathrm{O}$}

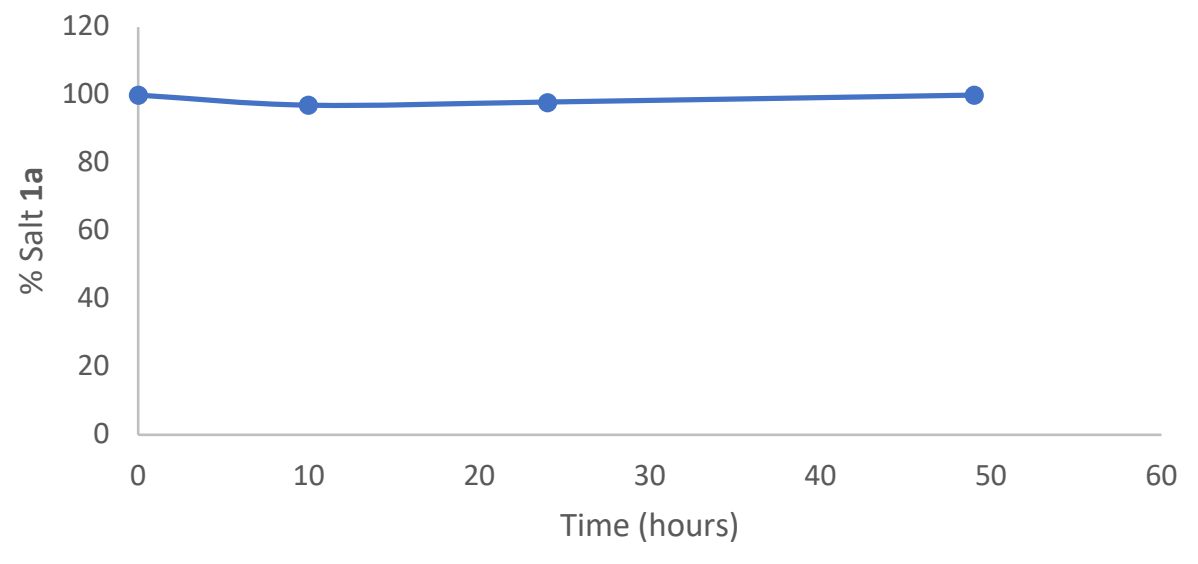

Stability Study B

1a $\left(7 \mathrm{mM}\right.$ in $\left.\mathrm{D}_{2} \mathrm{O}\right), \mathrm{NH}_{4} \mathrm{OAc}\left(20 \mathrm{mM}\right.$ in $\left.\mathrm{D}_{2} \mathrm{O}\right)$ and $\mathrm{DMF}\left(7 \mathrm{mM}\right.$ in $\left.\mathrm{D}_{2} \mathrm{O}\right)$ were monitored over 49 hours via ${ }^{1} \mathrm{H}-\mathrm{NMR}$.

\% Salt 1a Over Time

with $20 \mathrm{mM} \mathrm{NH}_{4} \mathrm{OAc}$

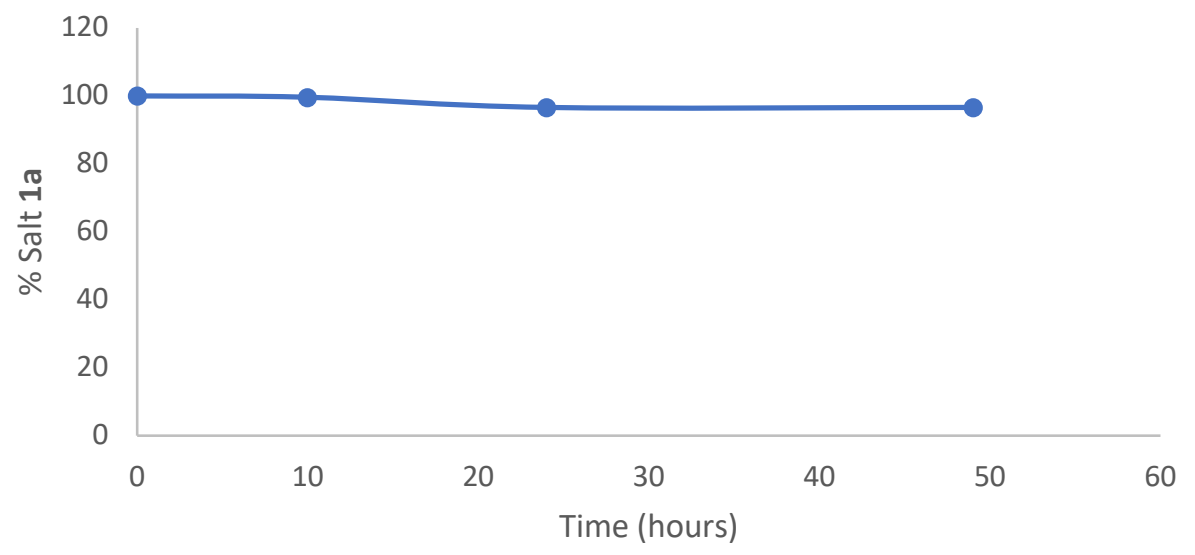


Stability Study $\mathrm{C}$

1a $\left(7 \mathrm{mM}\right.$ in $\left.\mathrm{D}_{2} \mathrm{O}\right), \mathrm{NH}_{4} \mathrm{OAc}\left(20 \mathrm{mM}\right.$ in $\left.\mathrm{D}_{2} \mathrm{O}\right)$, glutathione $\left(1 \mathrm{mM}\right.$ in $\left.\mathrm{D}_{2} \mathrm{O}\right)$ and $\mathrm{DMF}\left(7 \mathrm{mM}\right.$ in $\left.\mathrm{D}_{2} \mathrm{O}\right)$ were monitored over 49 hours.

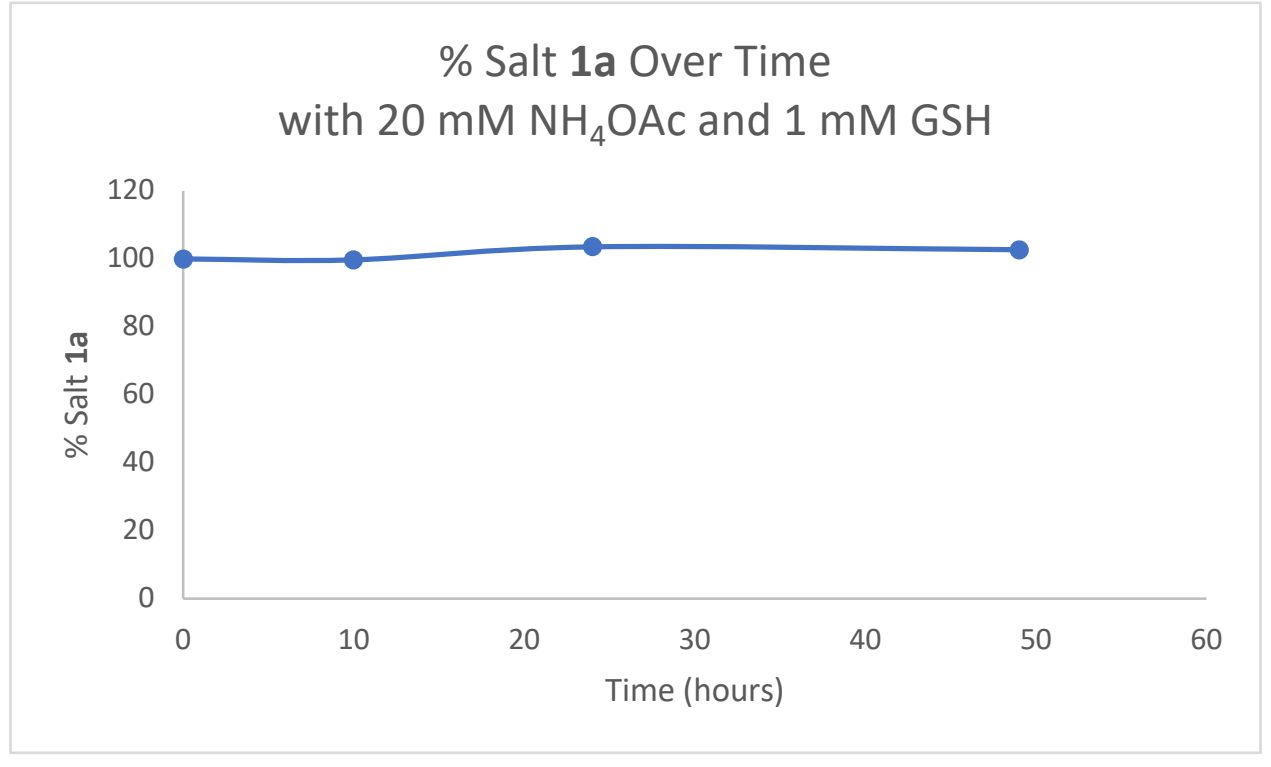

\section{Stability Study $D$}

1a $\left(7 \mathrm{mM}\right.$ in $\left.\mathrm{D}_{2} \mathrm{O}\right)$, glutathione $\left(7 \mathrm{mM}\right.$ in $\left.\mathrm{D}_{2} \mathrm{O}\right)$ and $\mathrm{DMF}\left(7 \mathrm{mM}\right.$ in $\left.\mathrm{D}_{2} \mathrm{O}\right)$ were monitored over 51 hours.

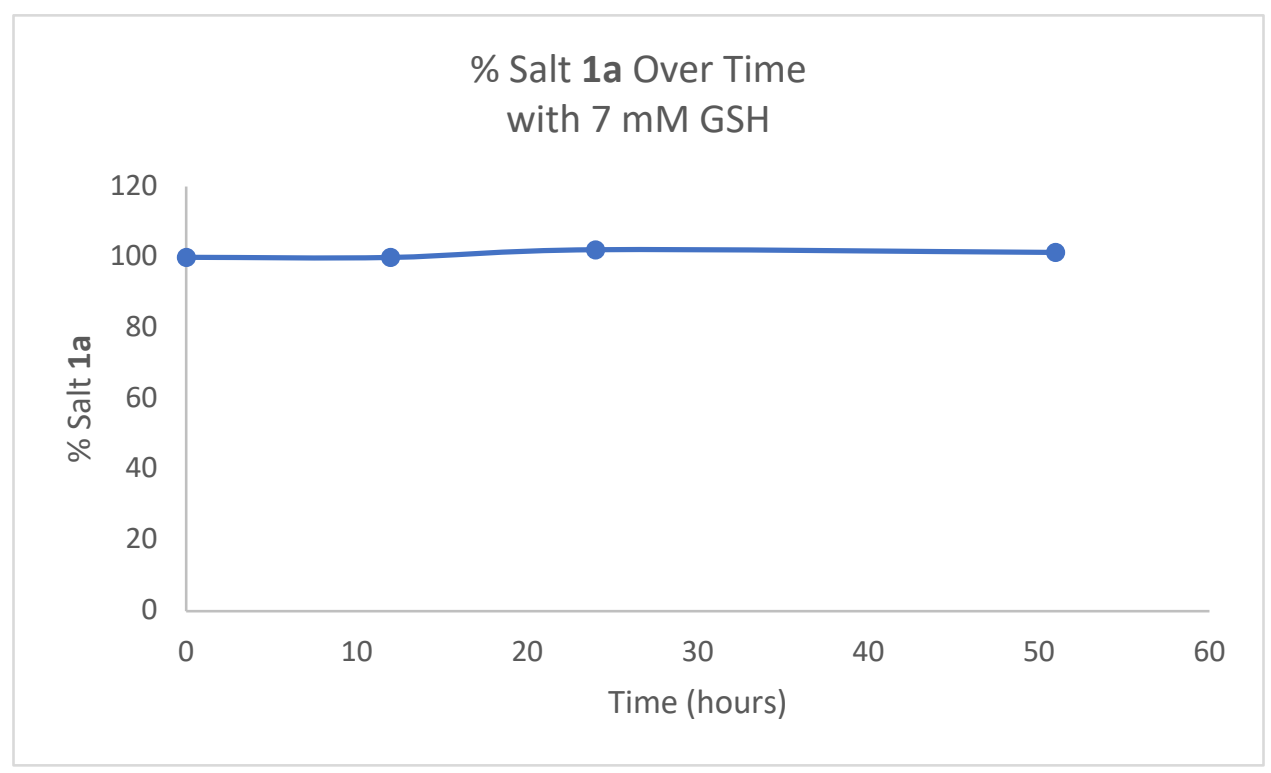


Stability Study E

$1 \mathrm{a}(7 \mathrm{mM}), \mathrm{NaHPO}_{4}(20 \mathrm{mM}, \mathrm{pH}$ 7.5) and DMF (7 mM) were monitored over 51 hours.

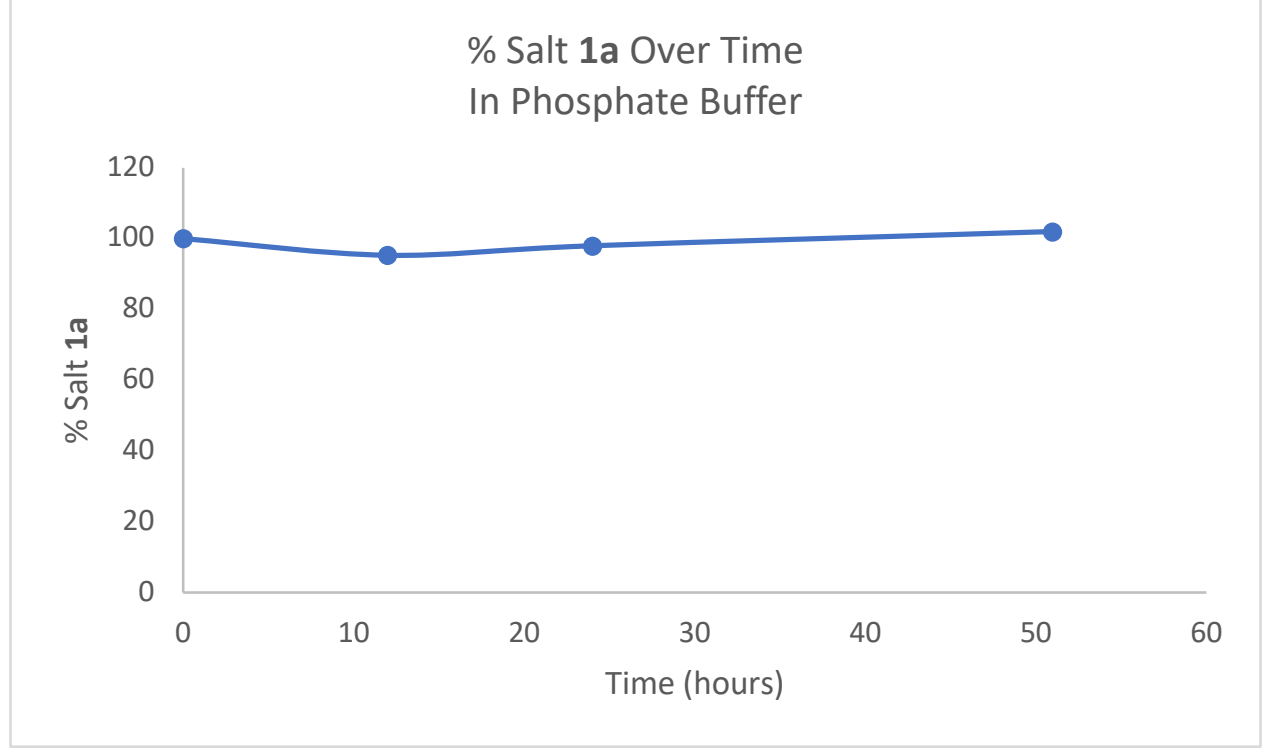

Stability Study F

1a (7 mM), NaHPO 4 (20 mM, pH 7.5), glutathione (7 mM) and DMF (7 mM) were monitored over 48 hours.

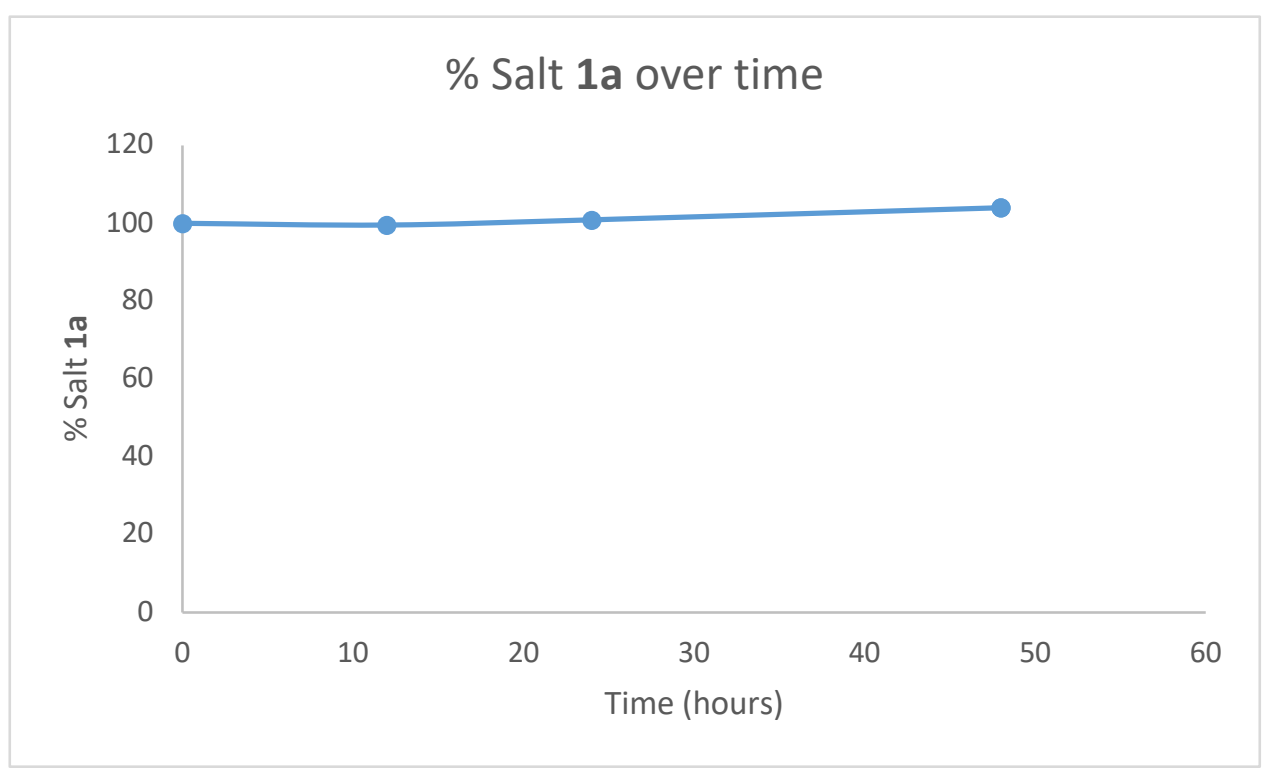


Stability Study G

1a $(100 \mu \mathrm{M}), \mathrm{NADH}(500 \mu \mathrm{M}), \mathrm{NaHPO} 4(\mathrm{pH} 7.4,50 \mathrm{mM})$ were monitored over 45 hours via LC/MS using $N$-acetyl-L-tryptophanamide $(250 \mu \mathrm{M})$ as an internal standard.

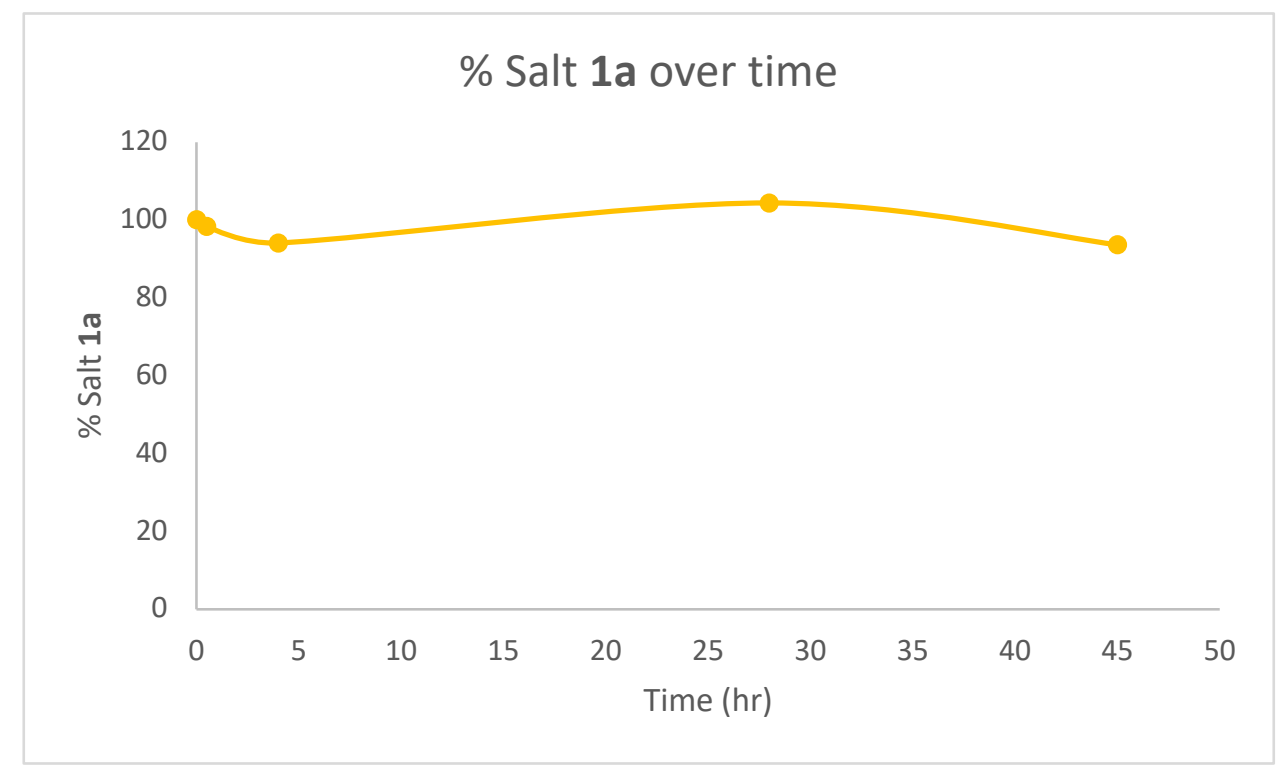

Stability Study $\mathrm{H}$

1a $(100 \mu \mathrm{M})$, was allowed to stand in Human Serum AB over 40 hours and monitored via LC/MS using $N$-acetyl-L-tryptophanamide $(250 \mu \mathrm{M})$ as an internal standard.

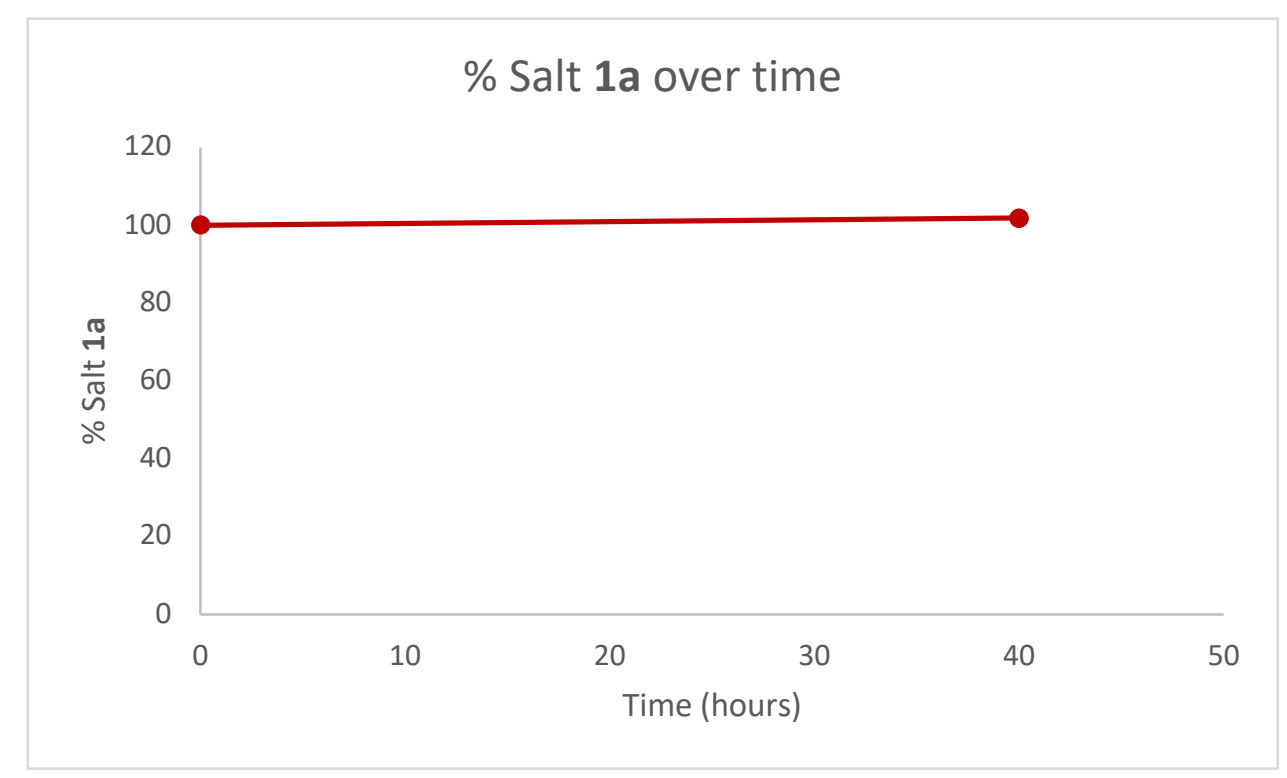




\section{Labelling of Lysozyme}

02JulyLysSSCheck_20190702172227 \#859-1303 RT: 2.67-4.02 AV: 445 NL: 1.56E5

T: ITMS + p ESI Full ms [500.00-2000.00]

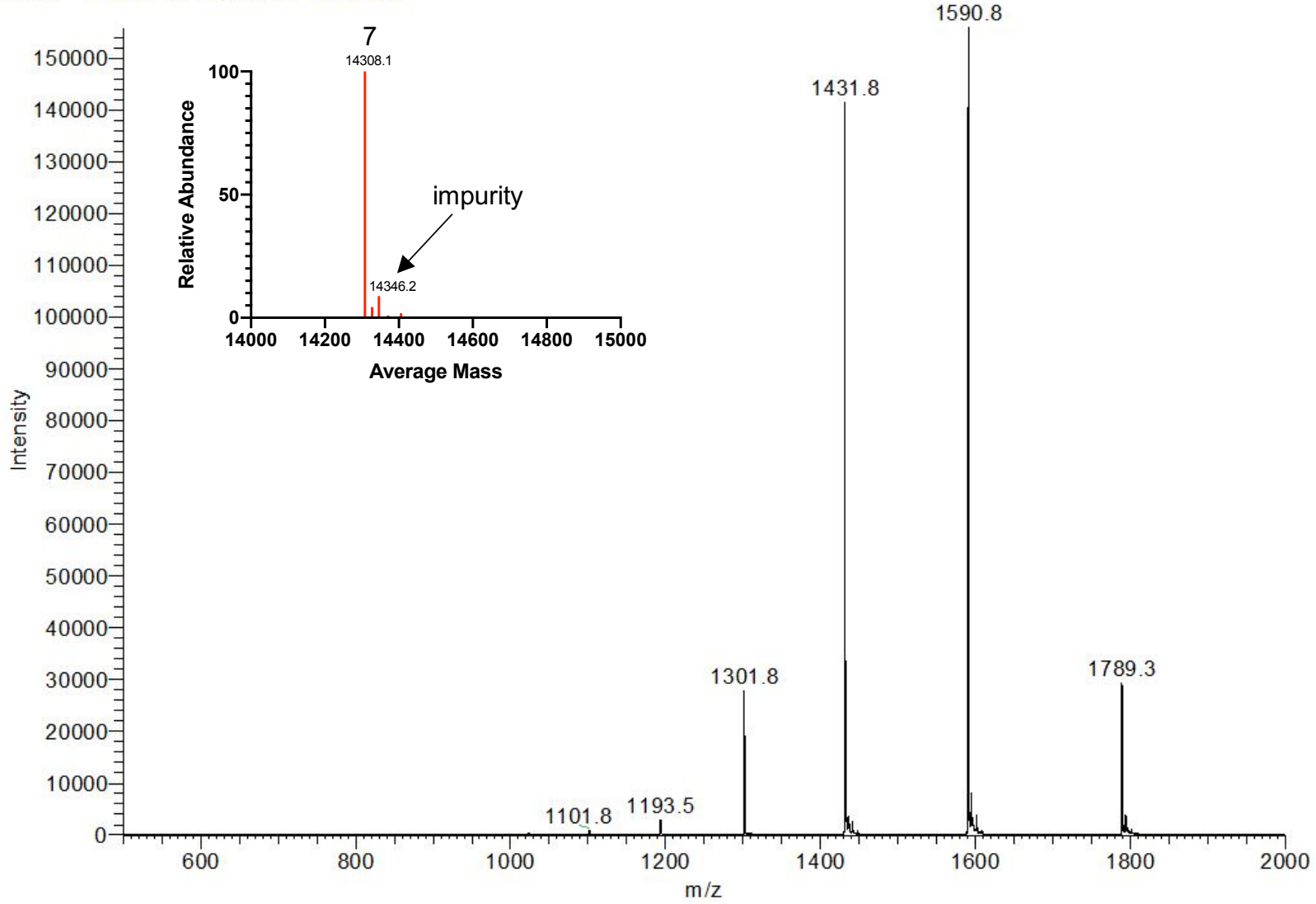

Figure 22. Mass spectrum of unmodified $7\left(T_{r}=2.67-4.02 \mathrm{~min}\right)$. 


\section{Labeling of Lysozyme with pyridinium salt 1a}

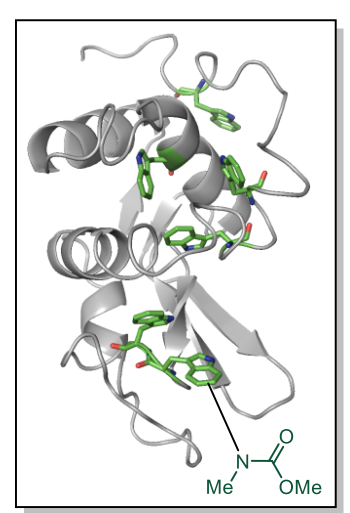

Labeling of lysozyme (7) with salt 1 a was performed by following general procedure B using 7 (32 $\mu \mathrm{L}, 0.93 \mathrm{mM}, 100 \mu \mathrm{M}$ final concentration), 1a (84 $\mu \mathrm{L}, 25 \mathrm{mM}, 7 \mathrm{mM}$ final concentration), $\mathrm{NH}_{4} \mathrm{OAc}(30 \mu \mathrm{L}, 200 \mathrm{mM}, \mathrm{pH}=6.9$, $20 \mathrm{mM}$ final concentration), glutathione $(15 \mu \mathrm{L}, 20 \mathrm{mM}, 1 \mathrm{mM}$ final concentration) and water $(139 \mu \mathrm{L})$ with an irradiation time of 30 minutes. The reaction mixture was analyzed directly via Method $B$ and was estimated to have proceeded in 79\% conversion, 9.5: 2: 1 mono: di: tri labelled, $16 \%$ glutathionylation. The reaction mixture was reduced with excess TCEP, confirming disulfide formation between lysozyme and GSH.

A replicate reaction with 7 (32 $\mu \mathrm{L}, 0.93 \mathrm{mM}, 100 \mu \mathrm{M}$ final concentration), 1a $\left(84 \mu \mathrm{L}, 25 \mathrm{mM}, 7 \mathrm{mM}\right.$ final concentration), $\mathrm{NH}_{4} \mathrm{OAc}(30 \mu \mathrm{L}, 200 \mathrm{mM}, \mathrm{pH}$ = 6.9, $20 \mathrm{mM}$ final concentration), glutathione (15 $\mu \mathrm{L}, 20 \mathrm{mM}, 1 \mathrm{mM}$ final concentration) and water $(139 \mu \mathrm{L})$ proceeded in an estimated $77 \%$ conversion, 12: 3: 1 mono:di:tri labelled, $16 \%$ glutathionylation. The reaction mixture was reduced with excess TCEP, confirming disulfide formation between lysozyme and GSH. 

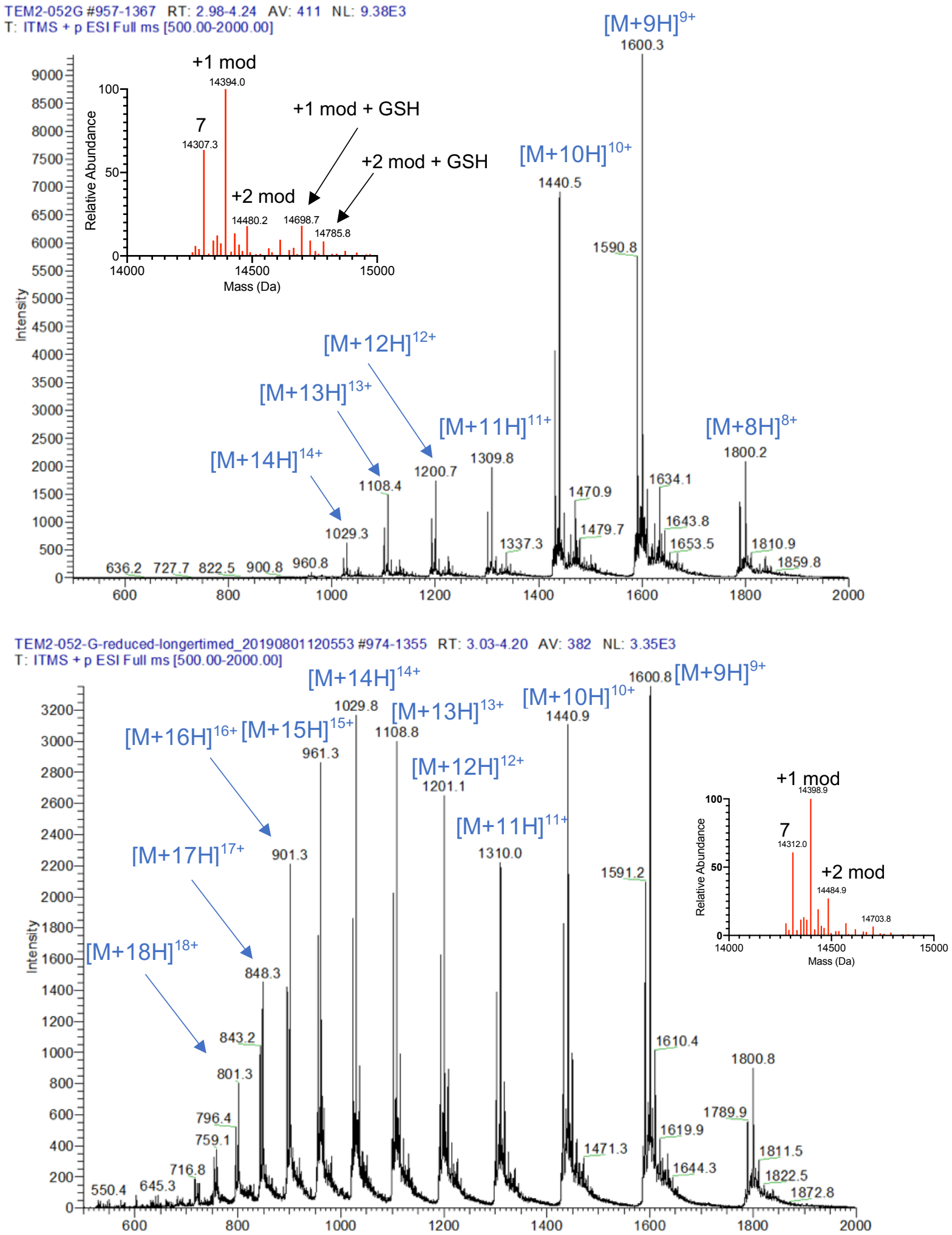

Figure 23. (A) Mass spectrum of conjugate 7a $\left(T_{r}=2.73-4.63 \mathrm{~min}\right)$. (B) Mass spectrum of reduced conjugate $7 \mathrm{a}\left(\mathrm{T}_{\mathrm{r}}=3.02-4.35 \mathrm{~min}\right)$. 


\section{Labeling of Lysozyme with pyridinium salt 1d}

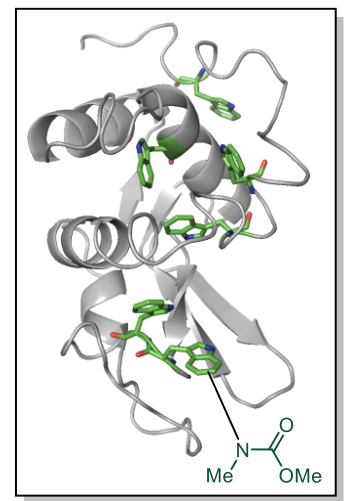

Labeling of lysozyme with salt $\mathbf{1 d}$ was performed by following general procedure B using $7(30 \mu \mathrm{L}, 1.0 \mathrm{mM}, 100 \mu \mathrm{M}$ final concentration), 1d (90 $\mu \mathrm{L}, 10 \mathrm{mM}, 3 \mathrm{mM}$ final concentration), glutathione $(90 \mu \mathrm{L}, 20 \mathrm{mM}, 6 \mathrm{mM}$ final concentration), $\mathrm{NH}_{4} \mathrm{OAc}(30 \mu \mathrm{L}, 200 \mathrm{mM}, \mathrm{pH} 6.9,20 \mathrm{mM}$ final concentration) and water $(60 \mu \mathrm{L})$ with a 60 minute sparge time followed by a 15 minute irradiation time. The reaction mixture was directly analyzed via LC/MS using method $B$ and was judged to have proceeded in $91 \%$ conversion with a 6:1 mono:di labelled ratio.

A replicate reaction using $7(30 \mu \mathrm{L}, 1.0 \mathrm{mM}, 100 \mu \mathrm{M}$ final concentration), $1 d(180 \mu \mathrm{L}, 5 \mathrm{mM}, 3 \mathrm{mM}$ final concentration), glutathione $(45 \mu \mathrm{L}, 40 \mathrm{mM}, 6$ $\mathrm{mM}$ final concentration), $\mathrm{NH}_{4} \mathrm{OAc}(30 \mu \mathrm{L}, 200 \mathrm{mM}, \mathrm{pH} 6.9,20 \mathrm{mM}$ final concentration) and water $(15 \mu \mathrm{L})$ proceeded with in $91 \%$ conversion, 6:1 mono:di labelled ratio.

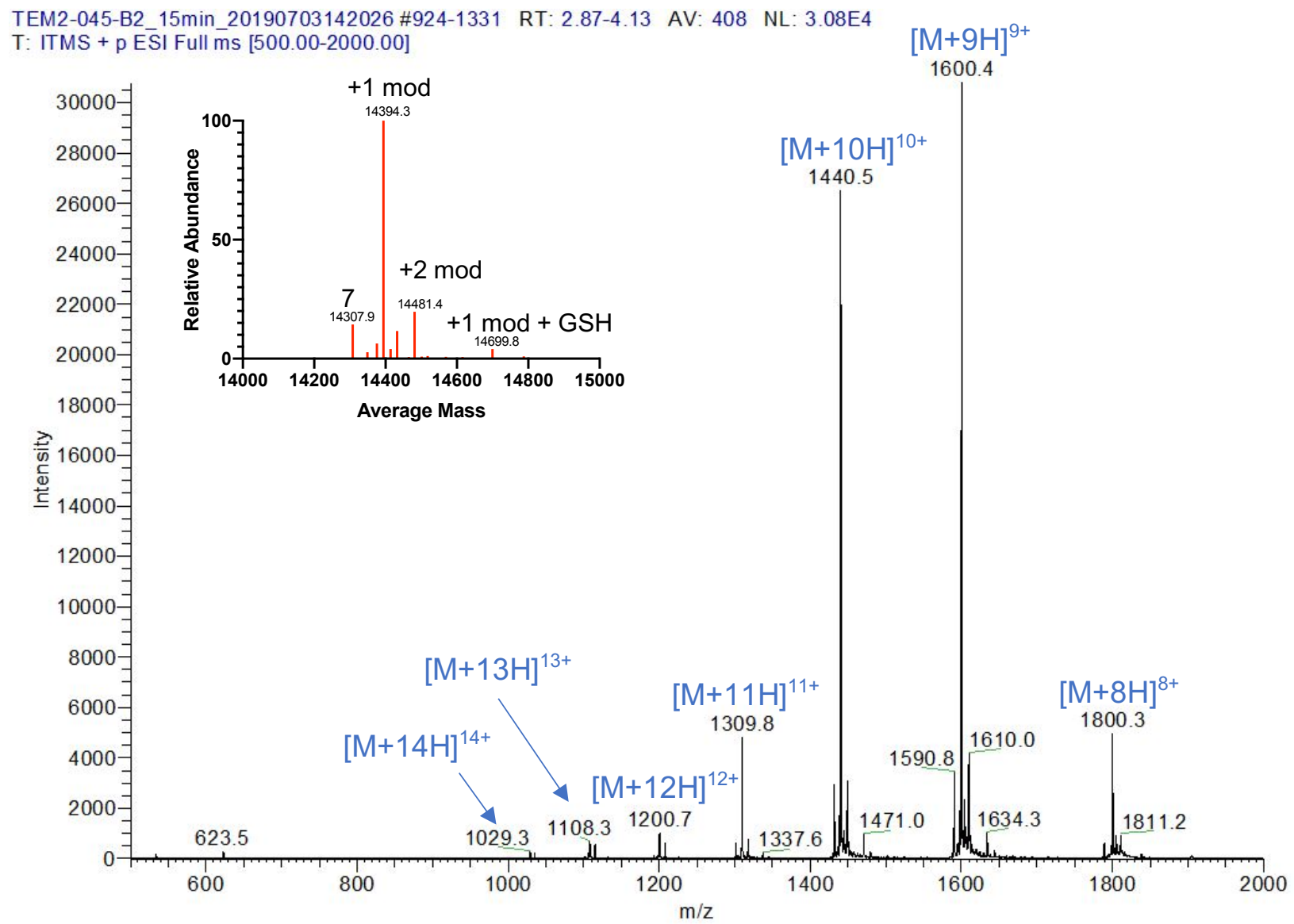

Figure 24. Mass spectrum of conjugate $7 a\left(T_{r}=2.87-4.13 \mathrm{~min}\right)$. 


\section{Labeling of lysozyme with pyridinium salt 1d using a $320 \mathrm{~nm}$ long-pass filter}

Labeling of lysozyme with salt $\mathbf{1 d}$ was performed by following general procedure $\mathrm{C}$ using 7 (30 $\mu \mathrm{L}, 1.0 \mathrm{mM}, 100 \mu \mathrm{M}$ final concentration), $1 \mathrm{~d}(180 \mu \mathrm{L}, 5 \mathrm{mM}, 3 \mathrm{mM}$ final concentration), glutathione (45 $\mu \mathrm{L}, 20 \mathrm{mM}, 3 \mathrm{mM}$ final concentration), $\mathrm{NH}_{4} \mathrm{OAc}(30 \mu \mathrm{L}, 200 \mathrm{mM}, \mathrm{pH} 6.9,20 \mathrm{mM}$ final concentration) and water $(15 \mu \mathrm{L})$ with a 60 minute sparge time followed by a 45 minute irradiation time. The reaction mixture was directly analyzed via LC/MS using method B and was judged to have proceeded in $>95 \%$ conversion with a 3:1 mono:di labelled ratio.

A replicate reaction using $7(30 \mu \mathrm{L}, 1.0 \mathrm{mM}, 100 \mu \mathrm{M}$ final concentration), 1d (180 $\mu \mathrm{L}, 5 \mathrm{mM}, 3$ $\mathrm{mM}$ final concentration), glutathione $\left(45 \mu \mathrm{L}, 20 \mathrm{mM}, 3 \mathrm{mM}\right.$ final concentration), $\mathrm{NH}_{4} \mathrm{OAc}(30 \mu \mathrm{L}$, $200 \mathrm{mM}$, pH 6.9, $20 \mathrm{mM}$ final concentration) and water (15 $\mu \mathrm{L}$ ) proceeded in 93\% conversion, 4:1 mono:di labelled ratio.

TEM2-046-A2 \#936-1365 RT: 2.91-4.23 AV: 430 NL: 4.36E4

T: ITMS + p ESI Full ms [500.00-2000.00]

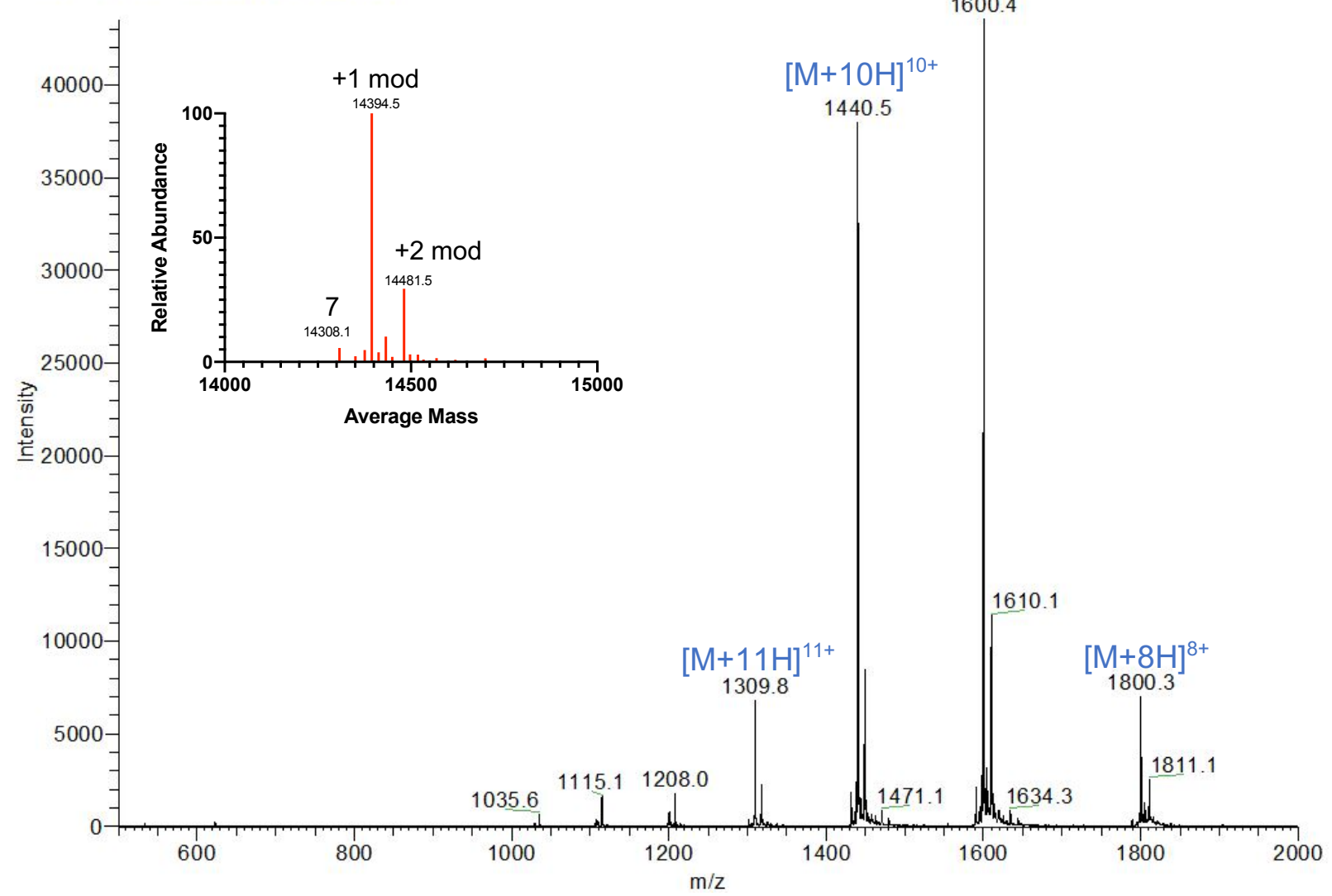

Figure 25. Mass spectrum of conjugate $7 a\left(T_{r}=2.91-4.23 \mathrm{~min}\right)$. 


\section{Lysozyme Activity Study}

\section{Sample Preparation for stock solutions of 7 and conjugate $7 \mathrm{a}$ :}

The standard lysozyme reaction solution, either post-irradiation to obtain modified 7 or preirradiation to obtain unmodified 7, was concentrated with an Amicon® Ultra $-0.5 \mathrm{~mL} 10 \mathrm{kDa}$ filter. A $20 \mu \mathrm{L}$ aliquot of the resulting concentrate was diluted to a total volume of $500 \mu \mathrm{L}$ with $50 \mathrm{mM}$ phosphate buffer (prepared using Optima ${ }^{\circledR}$ LC/MS water, $\mathrm{pH}=6.24$ ). The reconstituted lysozyme solution was concentrated using an Amicon® Ultra $-0.5 \mathrm{~mL} 10 \mathrm{kDa}$ filter. A $20 \mu \mathrm{L}$ portion of the resulting concentrate was diluted to $4.444 \mathrm{~mL}$ with $50 \mathrm{mM}$ phosphate buffer. A $175 \mu \mathrm{L}$ aliquot of the resulting solution was diluted to $1 \mathrm{~mL}$ with $50 \mathrm{mM}$ Phosphate Buffer to yield the desired lysozyme stock solution concentration.

The activity of Lysozyme was studied by adapting the procedure from Millipore Sigma ${ }^{13}$ as follows: using stock solutions that were prepared as described above: A solution of $7(0.1 \mathrm{~mL})$ was added to a solution of Micrococcus lysodeikticus Cells $(2.5 \mathrm{~mL}, 0.15 \mathrm{mg} / \mathrm{mL})$ and the decrease in the $\mathrm{Abs}_{450}$ was measured for 5 minutes. This experiment was performed in replicate for both conjugate $\mathbf{7 a}$ and unmodified 7 . Samples for each replicate were prepared individually as described above.

\begin{tabular}{|c|c|}
\hline & $\begin{array}{c}\text { Average Decrease in } \mathrm{A}_{450} \\
\text { (Abs/min) }\end{array}$ \\
\hline Control 7 & $0.009 \pm 0.001$ \\
\hline Conjugate 7a & $0.006 \pm 0.001$ \\
\hline
\end{tabular}

Table 2. A comparison of the average decrease in absorbance at $450 \mathrm{~nm}$ for the control and labeling reactions.

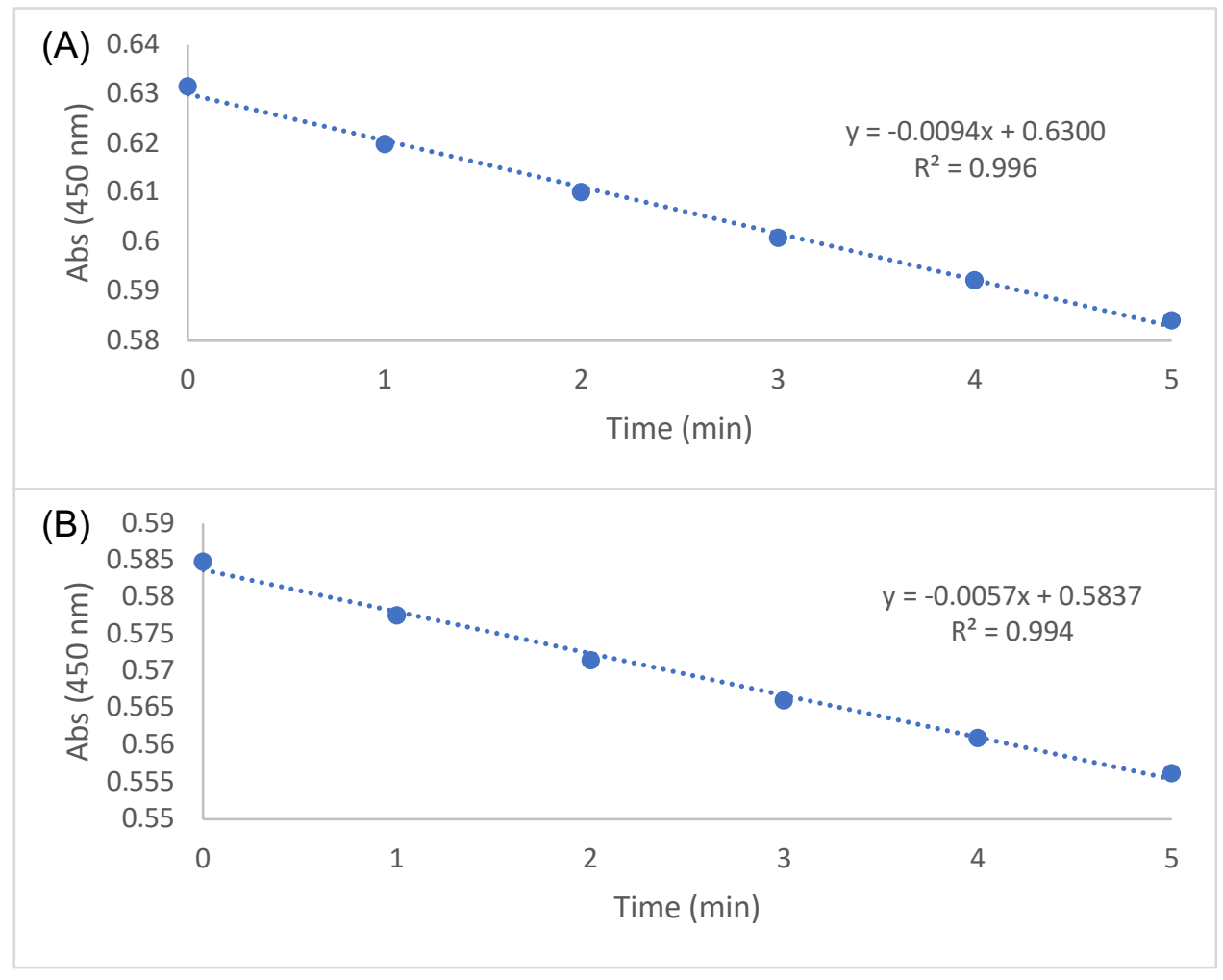

Figure 26. (A) Average $\Delta A_{450}$ for 7. (B) Average $\Delta A_{450}$ for $7 a$. 


\section{References}

1) Furuya, T.; Kaiser, H.M.; Ritter, T. Angew. Chem Int. Ed. 2008, 47, 5993.

2) Greulich, T.; Daniliuc, C.G.; Studer, A. Org. Lett. 2015, 17, 254.

3) Marzorati, L.; Di Vitta, P. B.; Wladislaw, B.; Schpector, J. Z.; Di Vitta, Claudio. Heterocycles. 2009, 78, 1223.

4) DiMauro, E.F.; Kozlowski, M.C. J. Chem. Soc. Perkin Trans. 2002, 3, 439.

5) Basch, C.H.; Liao, J.; Xu, J.; Paine, J. J.; Watson, M. P. J. Am. Chem. Soc. 2017, 139, 5313.

6) Holt, D.; Gaunt, M. J. Angew. Chem. Int. Ed. 2015, 54, 27, 7857-7861.

7) Dai, X.; Li, C. J. Am. Chem. Soc. 2016, 138, 16, 5433-5440.

8) Horatscheck, A.; Wagner, M. Sc. S.; Ortwein, D. I. J.; Kim, B. G.; Lisurek, M.; Beiligny, S.; Schutz, A.; Rademann, J. Angew. Chem. Int. Ed. 2012, 51, 37, 9441-9447.

9) Horatscheck, A.; Wagner, S.; Ortwein, J; Kim, B.G.; Lisurek, M.; Beligny, S.; Schütz, A.; Rademann, J. Angew. Chem. Int. Ed. 2012, 51, 37, 9441.

10) Jachmann, M.; Nokura, Y.; Ikegami, H. PCT, Int. Appl, 2008130021 , October 30, 2008.

11) Liardo, E.; Lombárdía, N. R.; Morís, F.; Rebolledo, F.; González-Sabín, J. ACS Catal. 2017, 7, 4768-4774.

12) QB3 Berkeley. Lys-C or Trypsin In-Solution Protein Digest Protocol. http://qb3.berkeley.edu/pmsl/wp-content/uploads/2016/06/Enzymatic-digestion-insolution.pdf

13) Heath, H. Proc. R. Soc. London. Ser. A. Math. Phys. Sci. 1956, 235, 518-536.

14) Parker, C. A., Photoluminescence of Solutions , Elsevier, Amsterdam, 1968

15) Millipore Sigma. Enzymatic Assay of Lysozyme (EC 3.2.1.17). https://www.sigmaaldrich.com/technical-documents/protocols/biology/enzymatic-assayof-lysozyme.html 

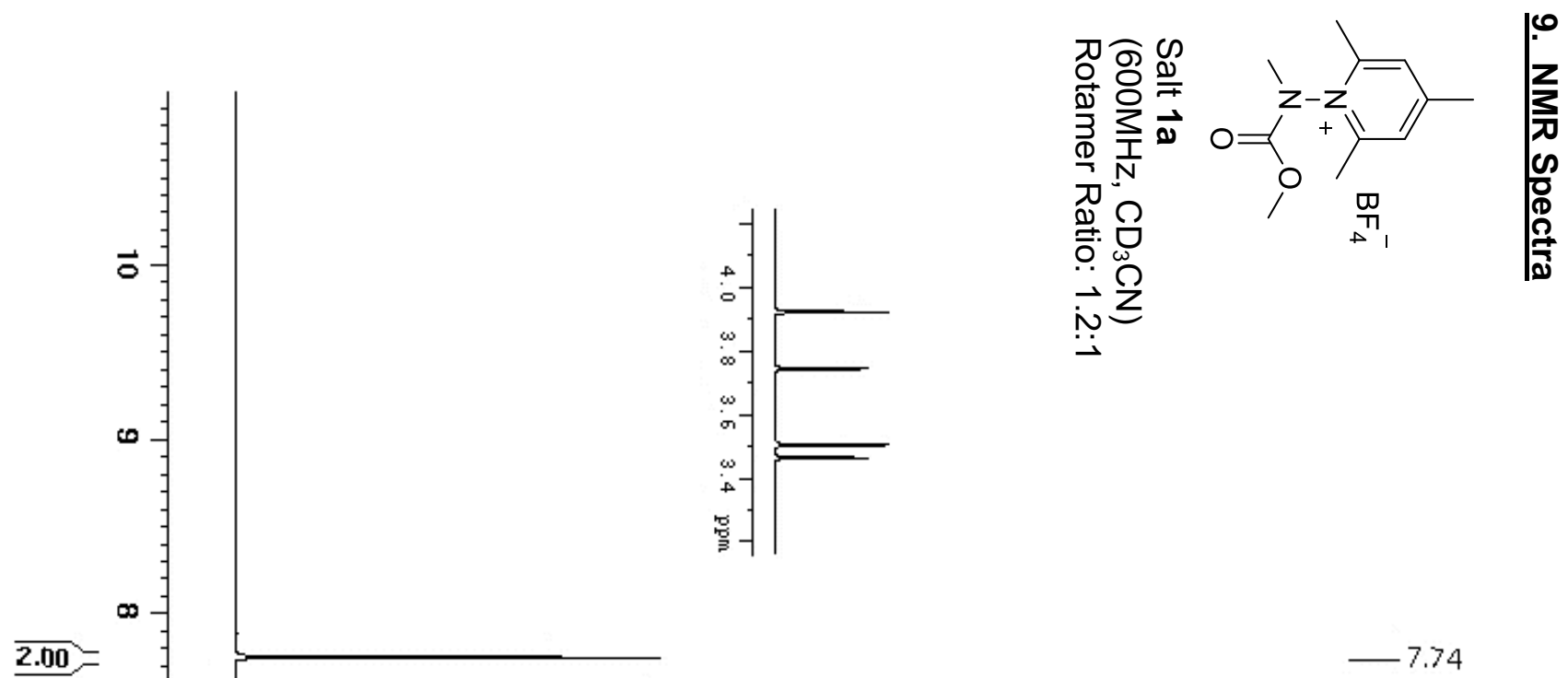

$\infty$
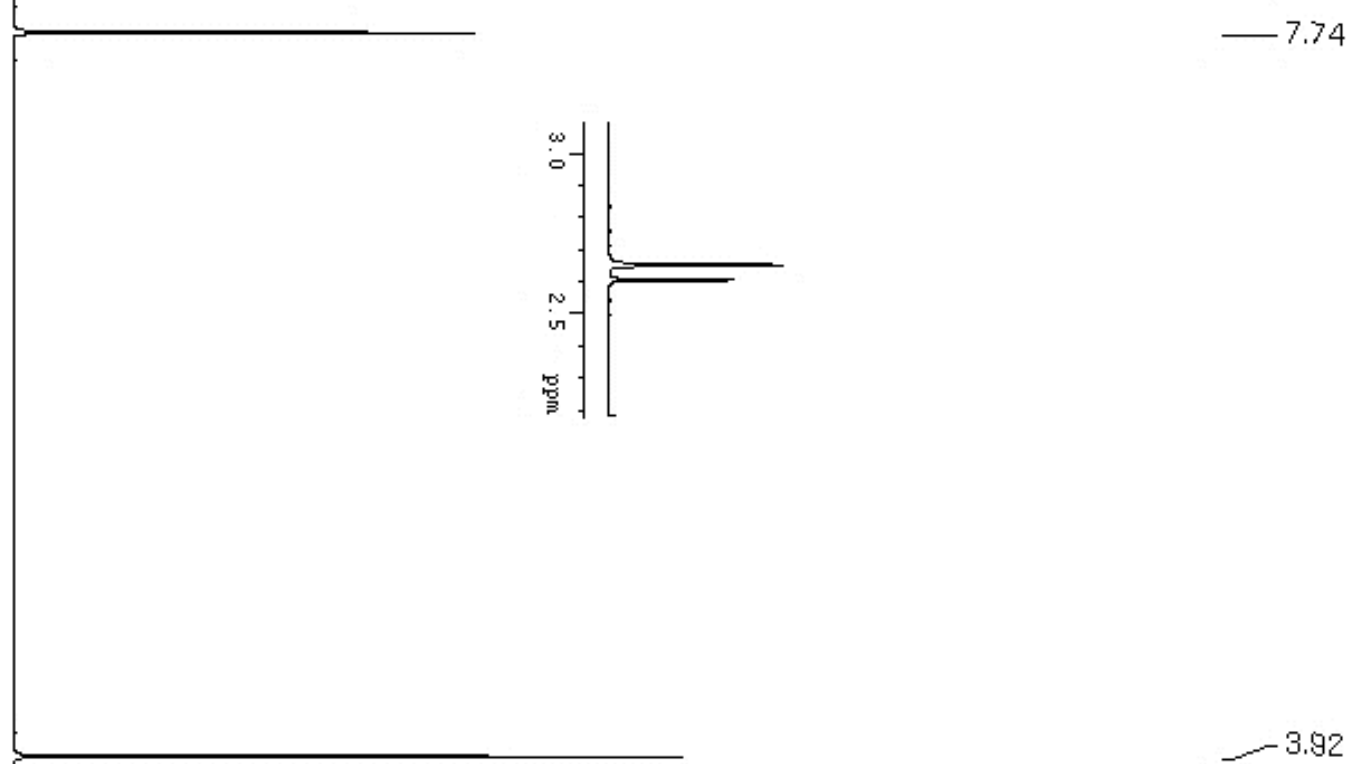

$\overline{1.72}=\Delta$

1.42

$\frac{1.72}{1.36}$

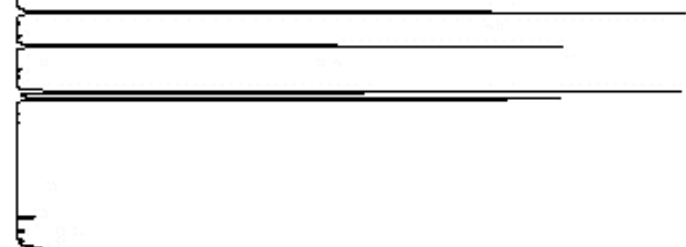

$--3.74$

$--3.74$

$\omega$

6.21

w-

2.98

$-2.65$

$-3.46$

N

E

등

$D$ 

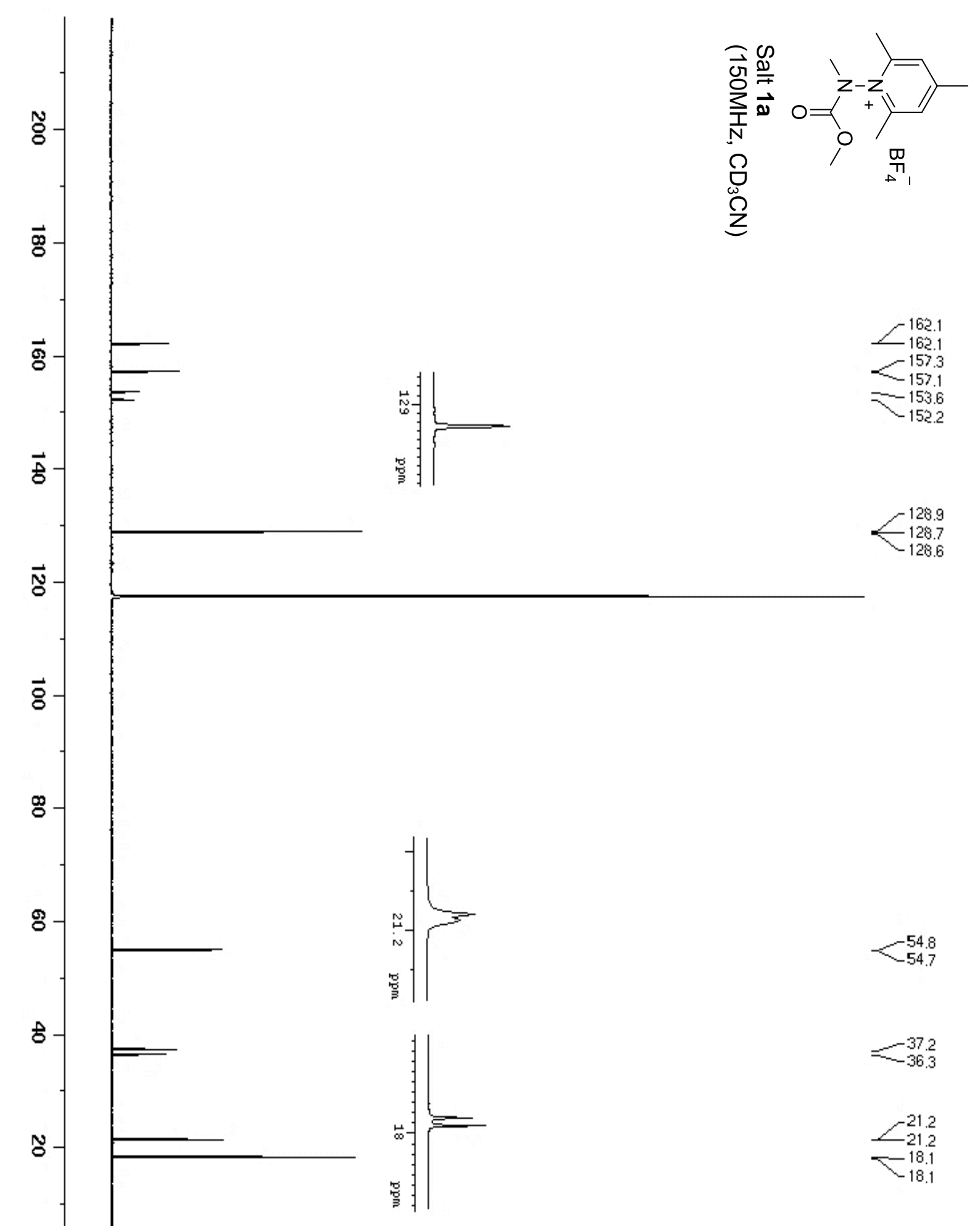


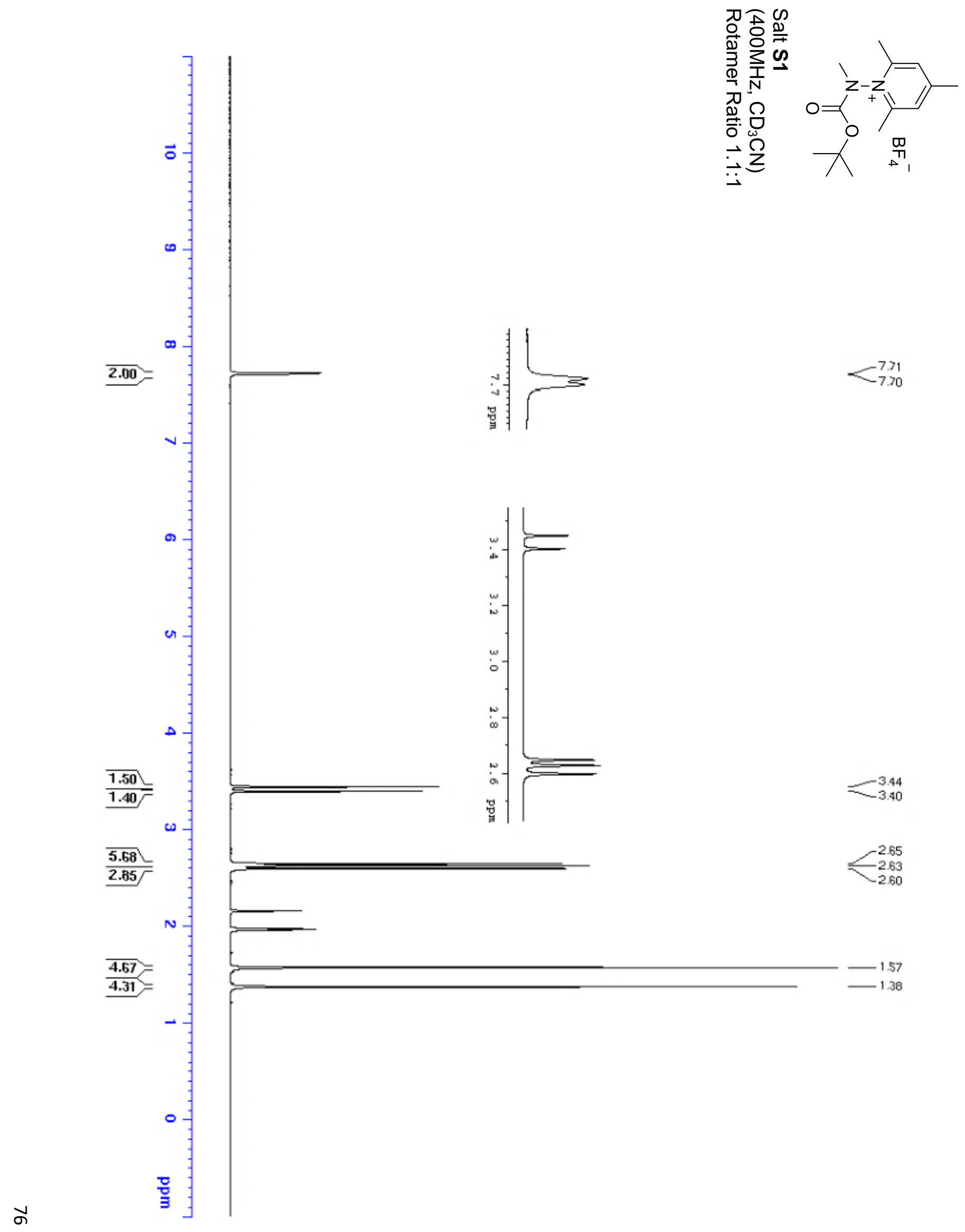




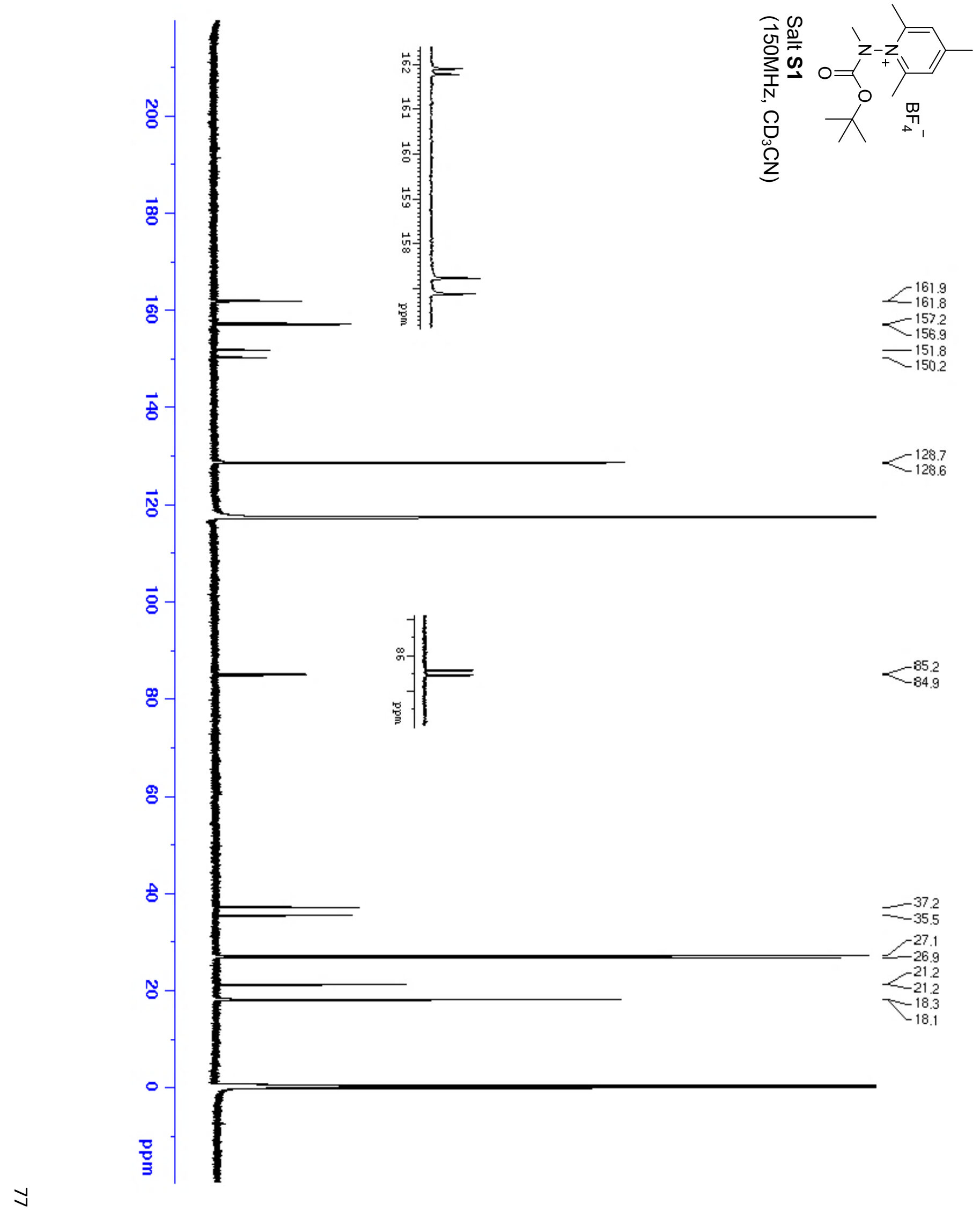




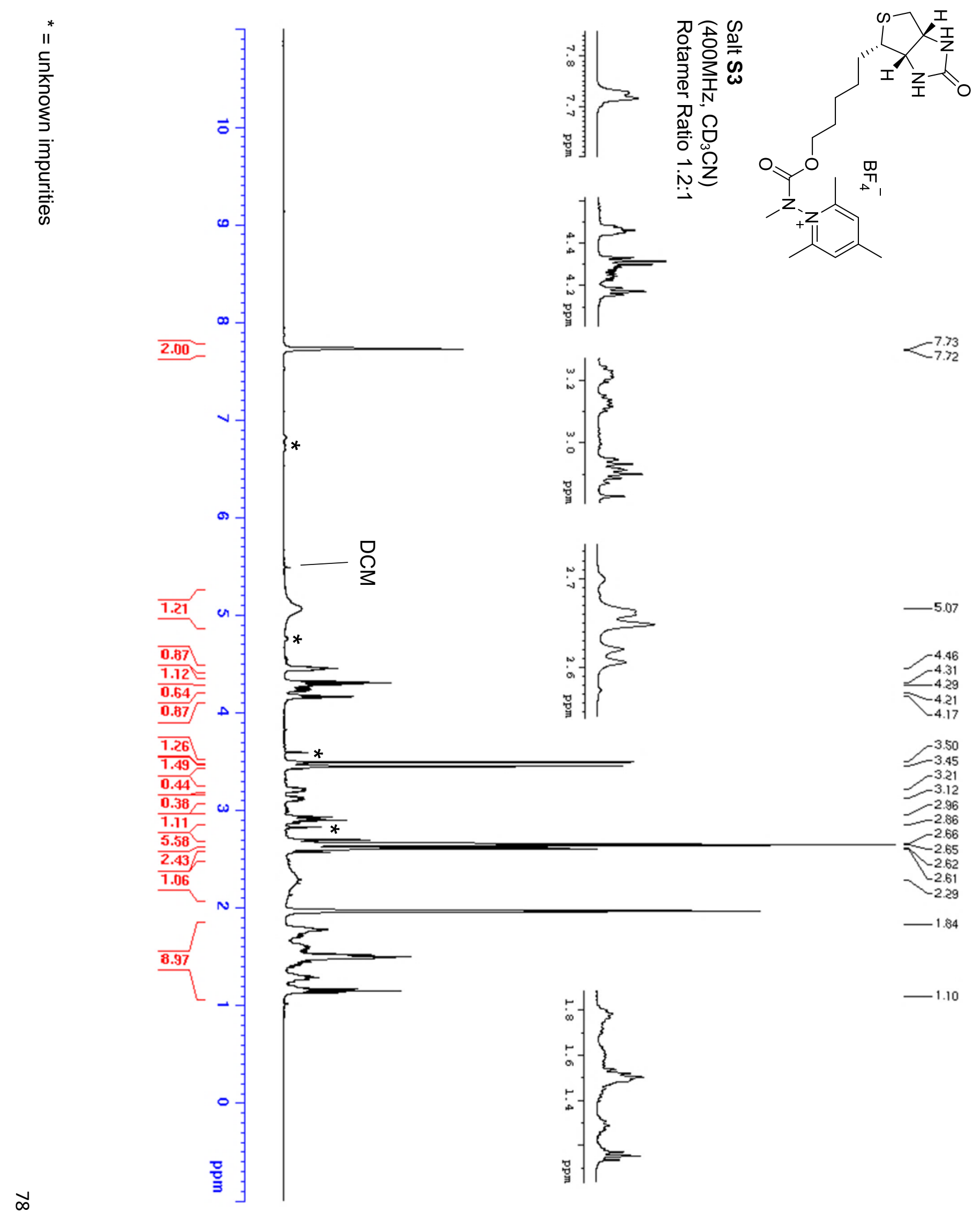




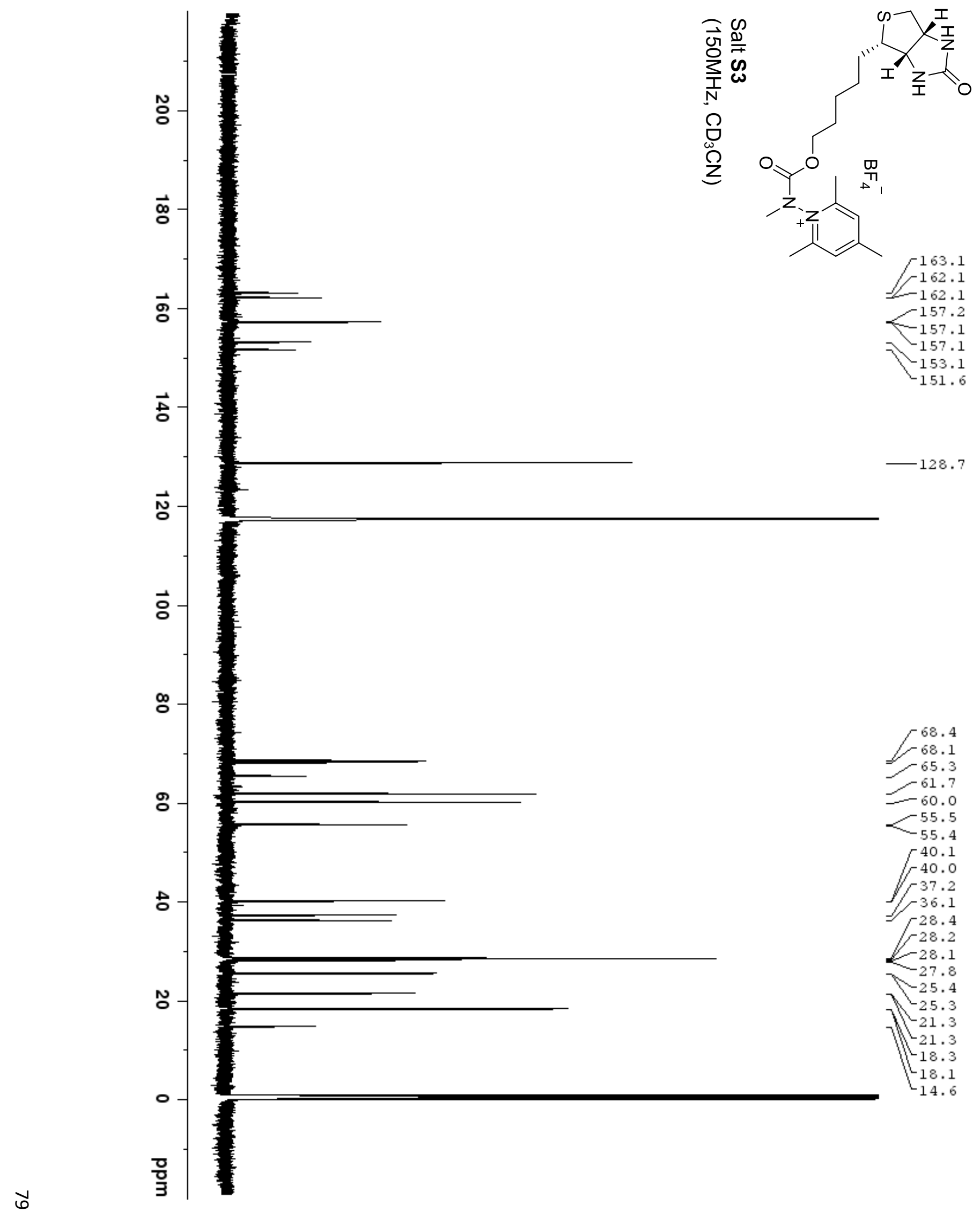




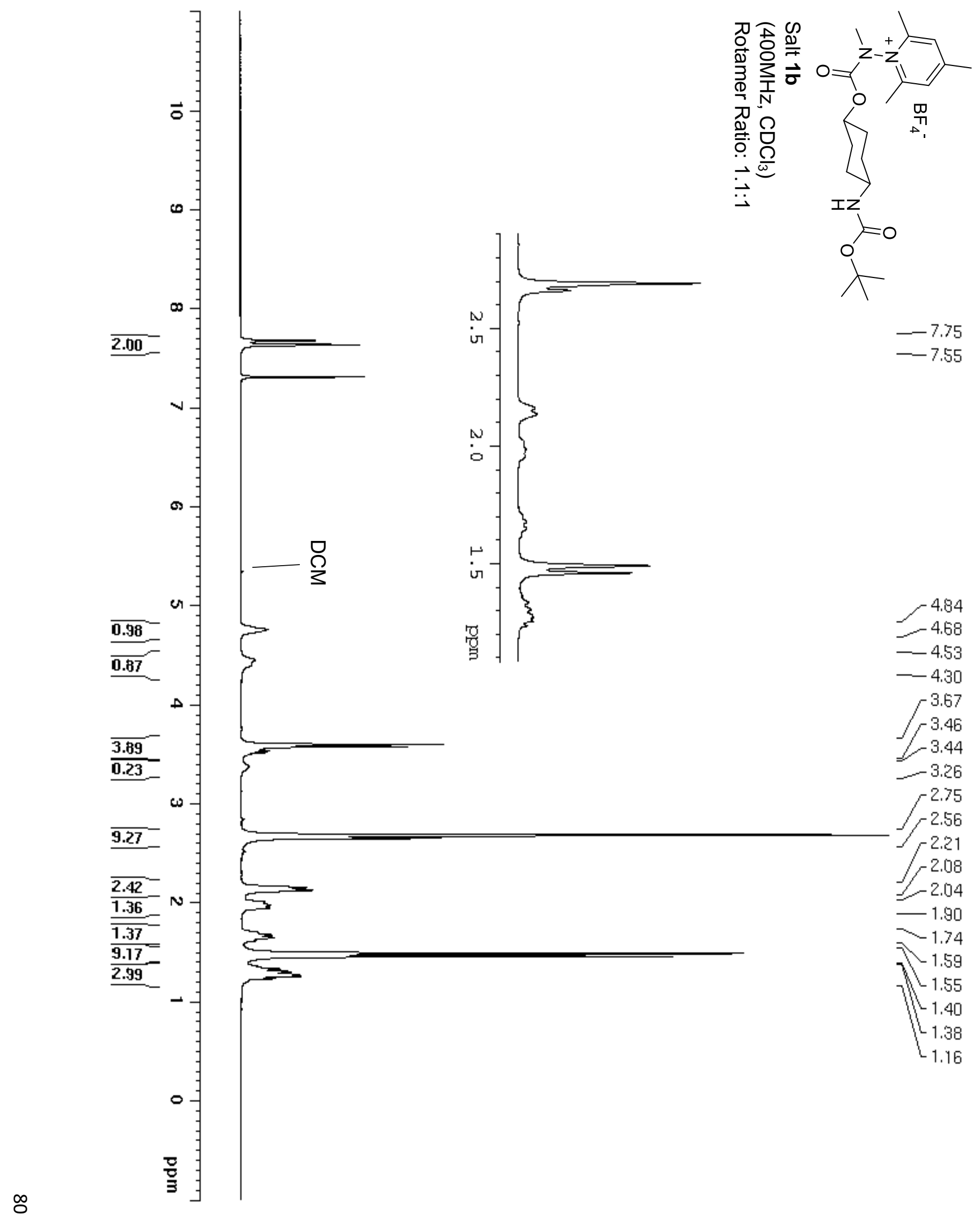




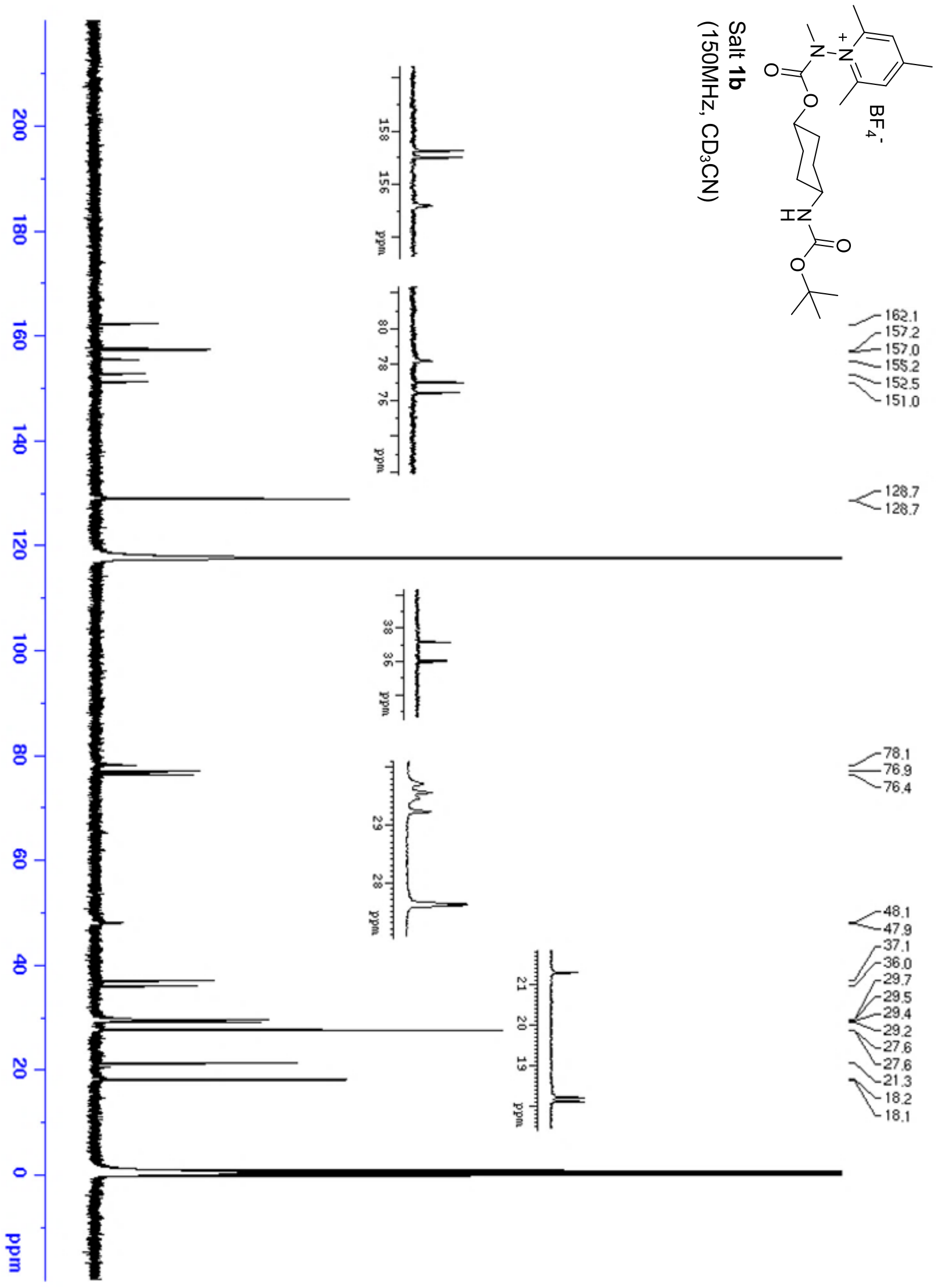




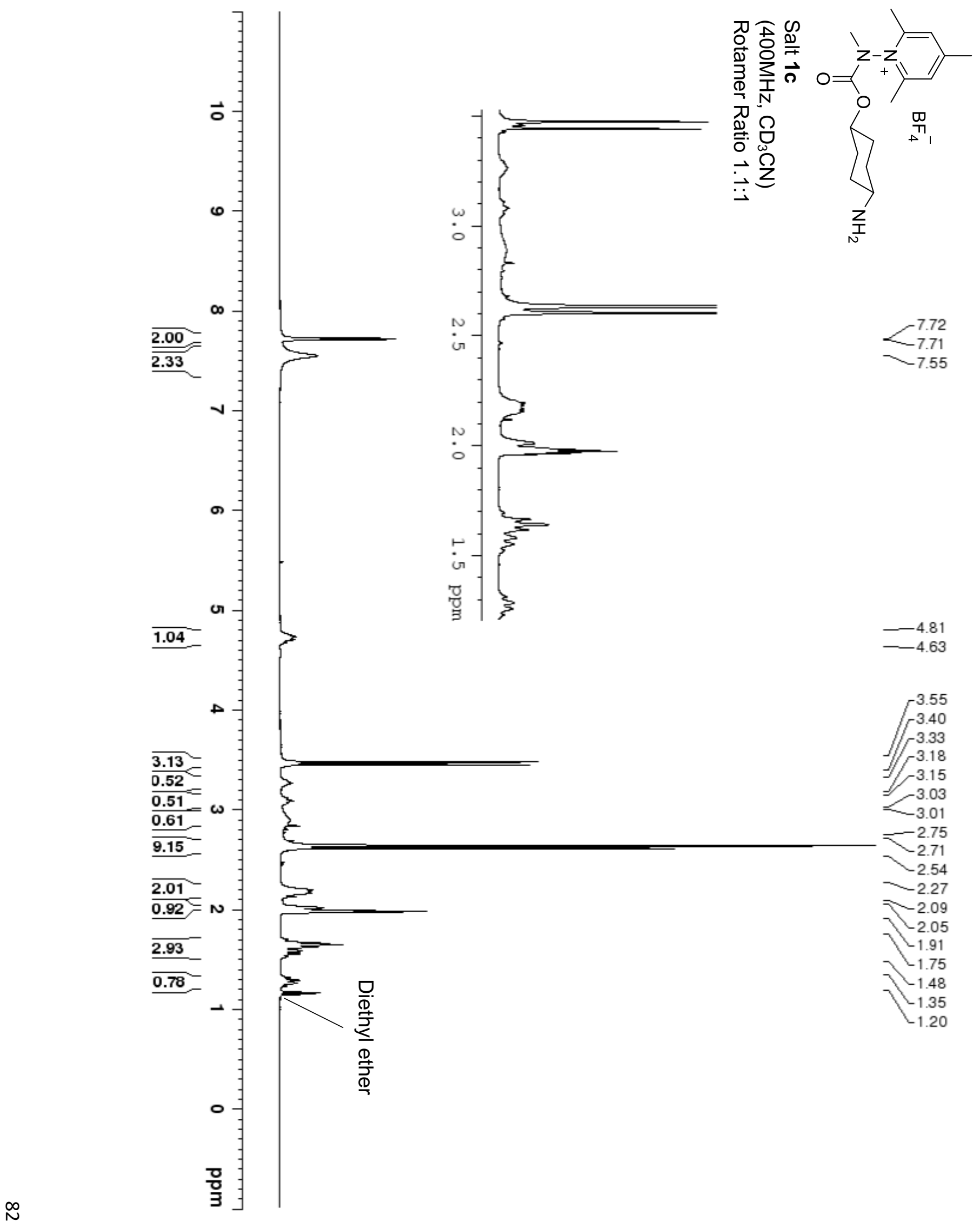




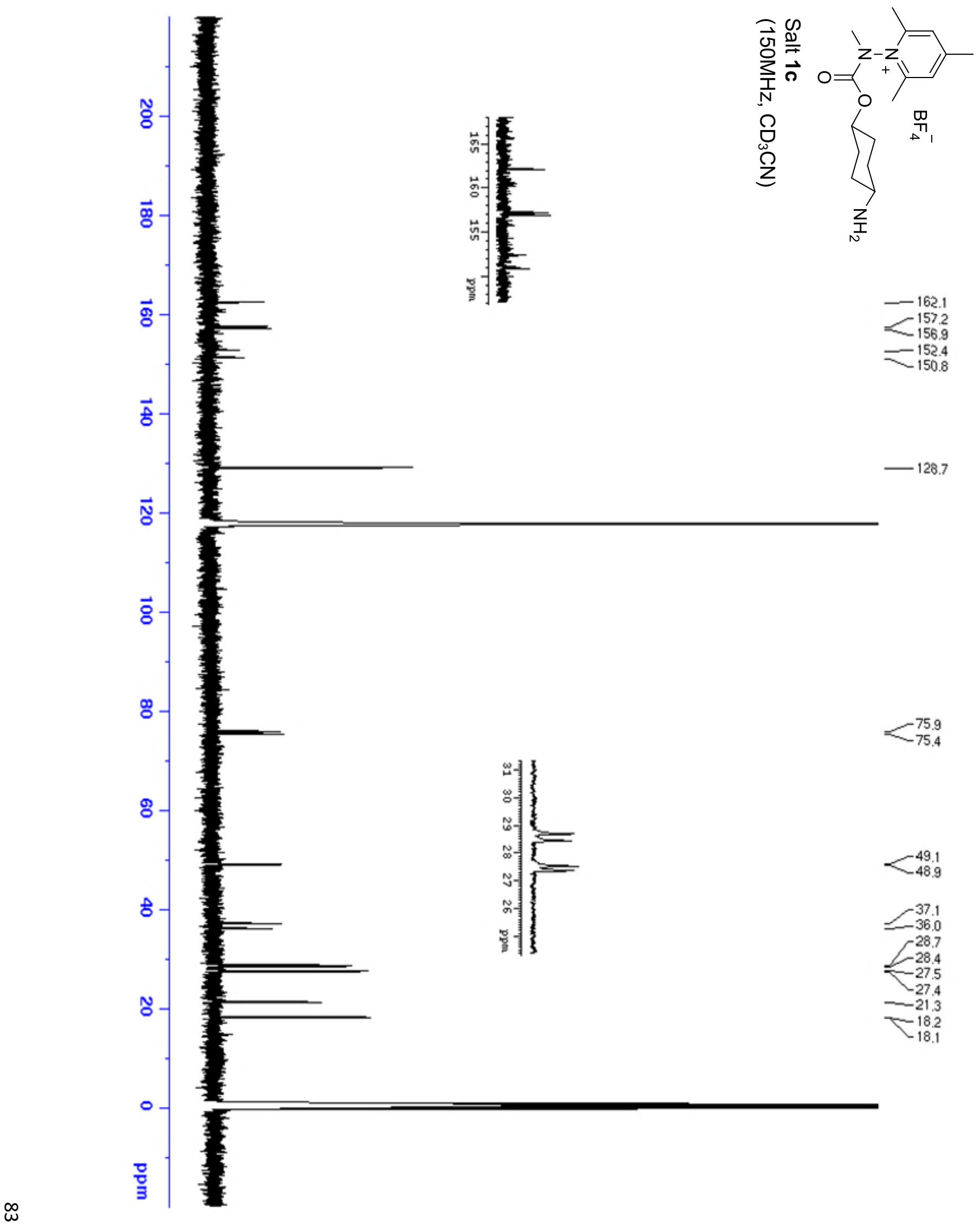




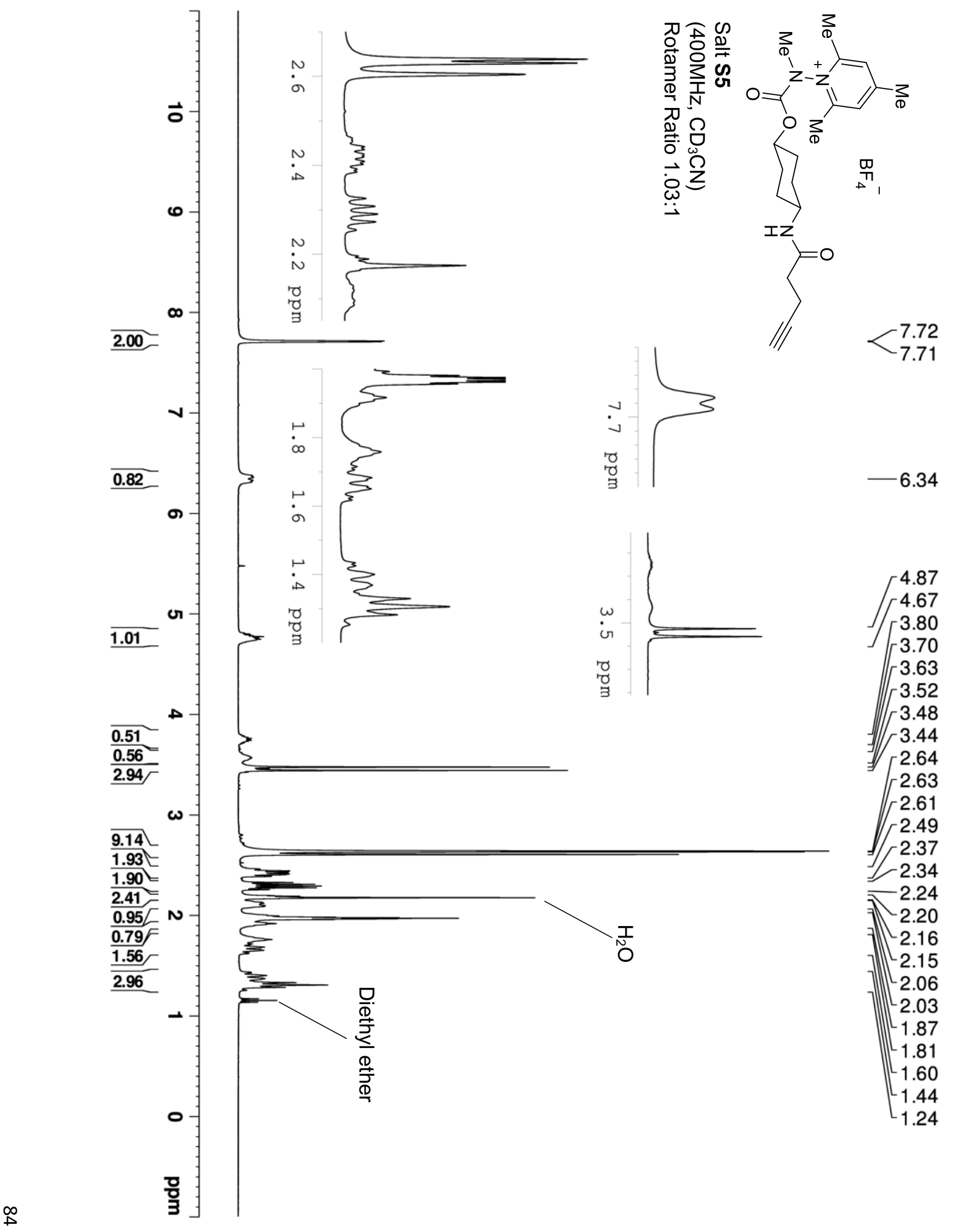




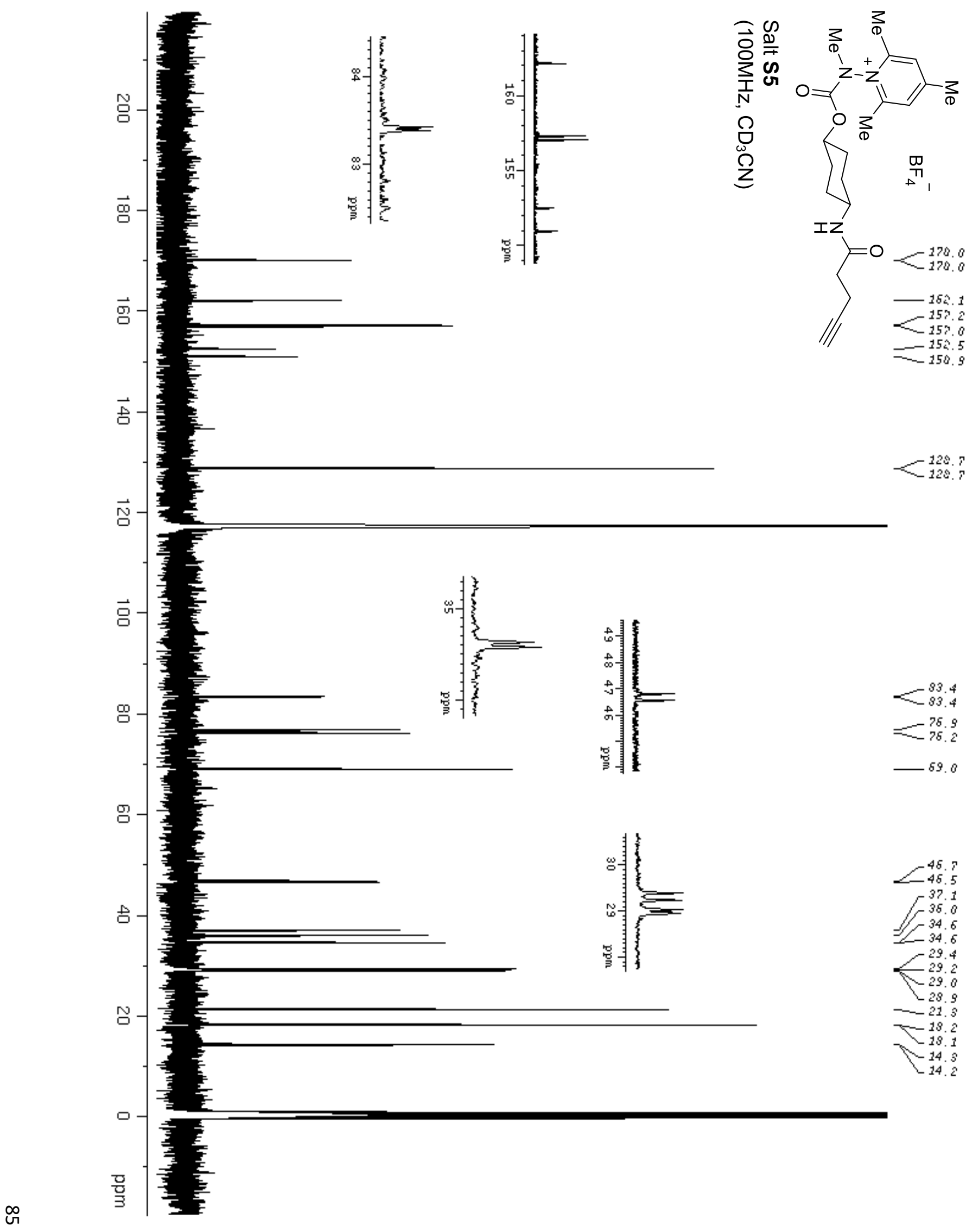




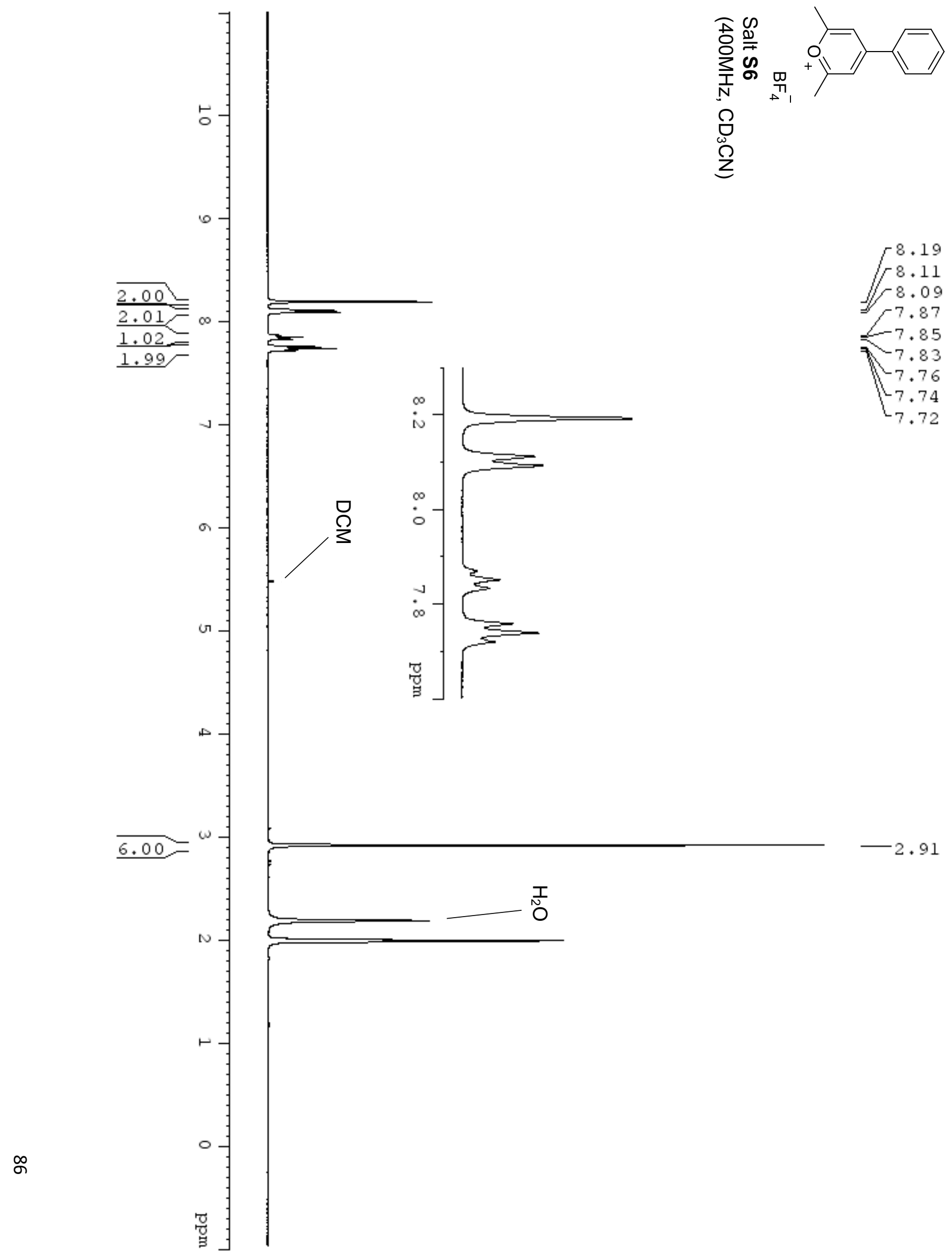




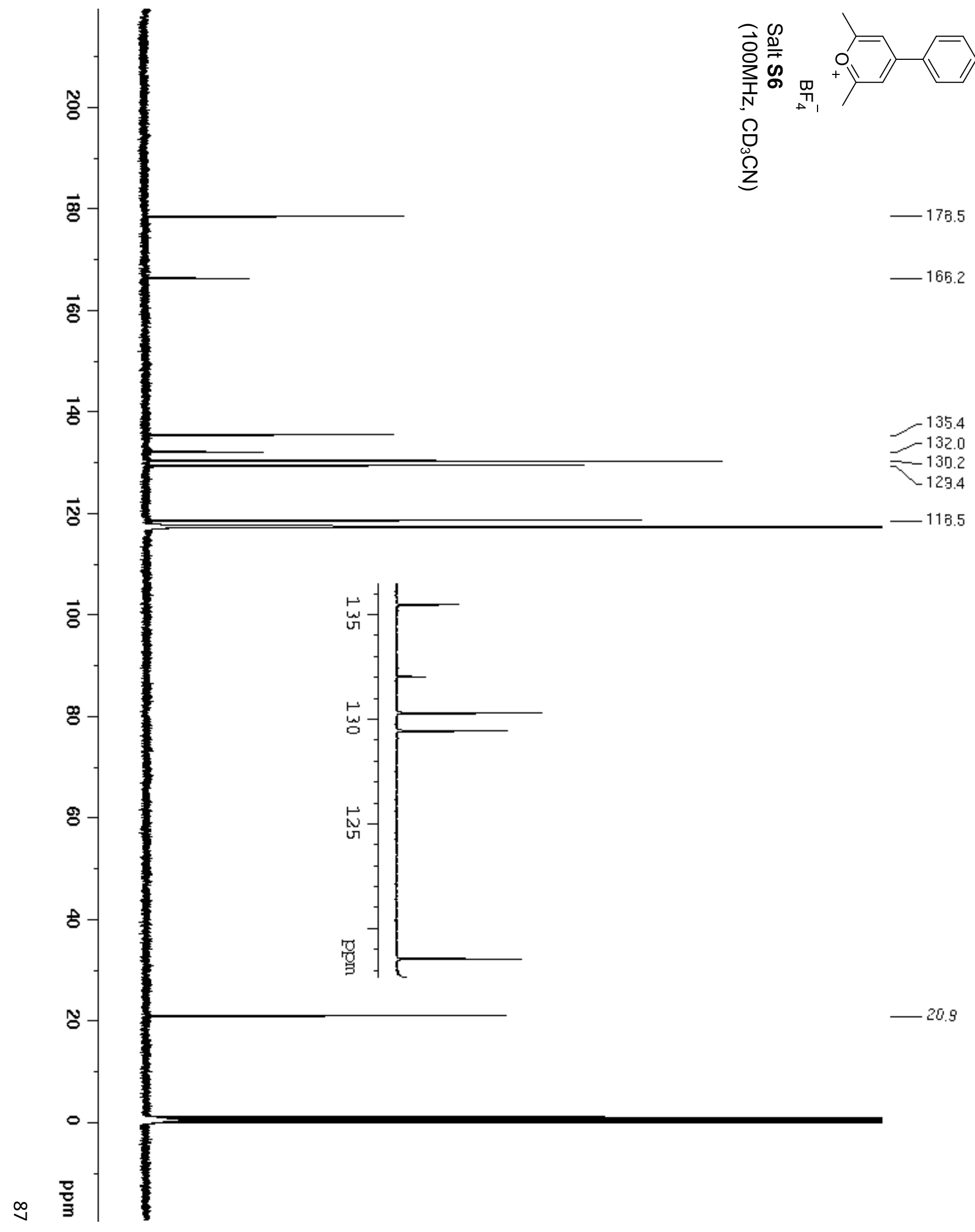




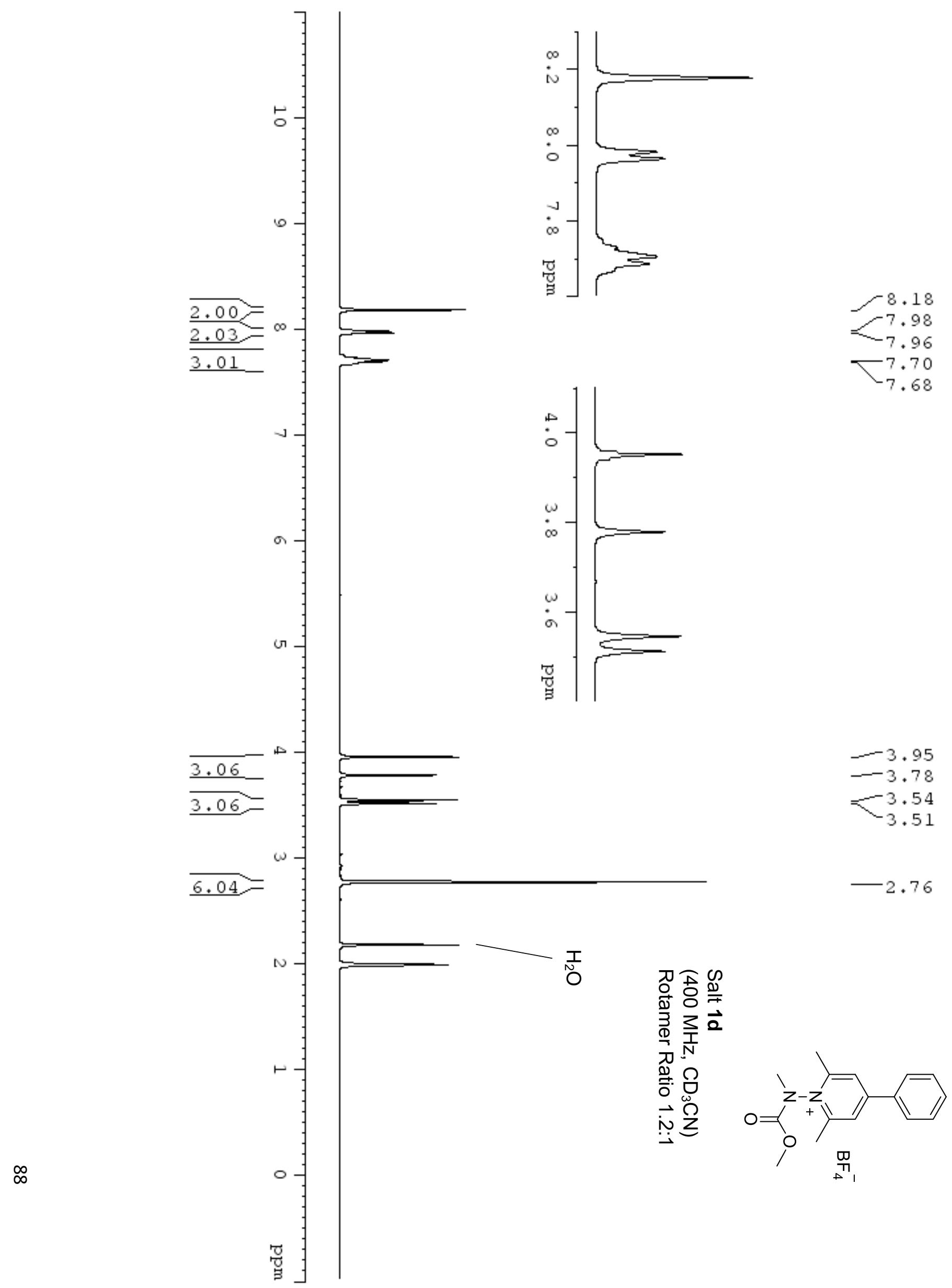




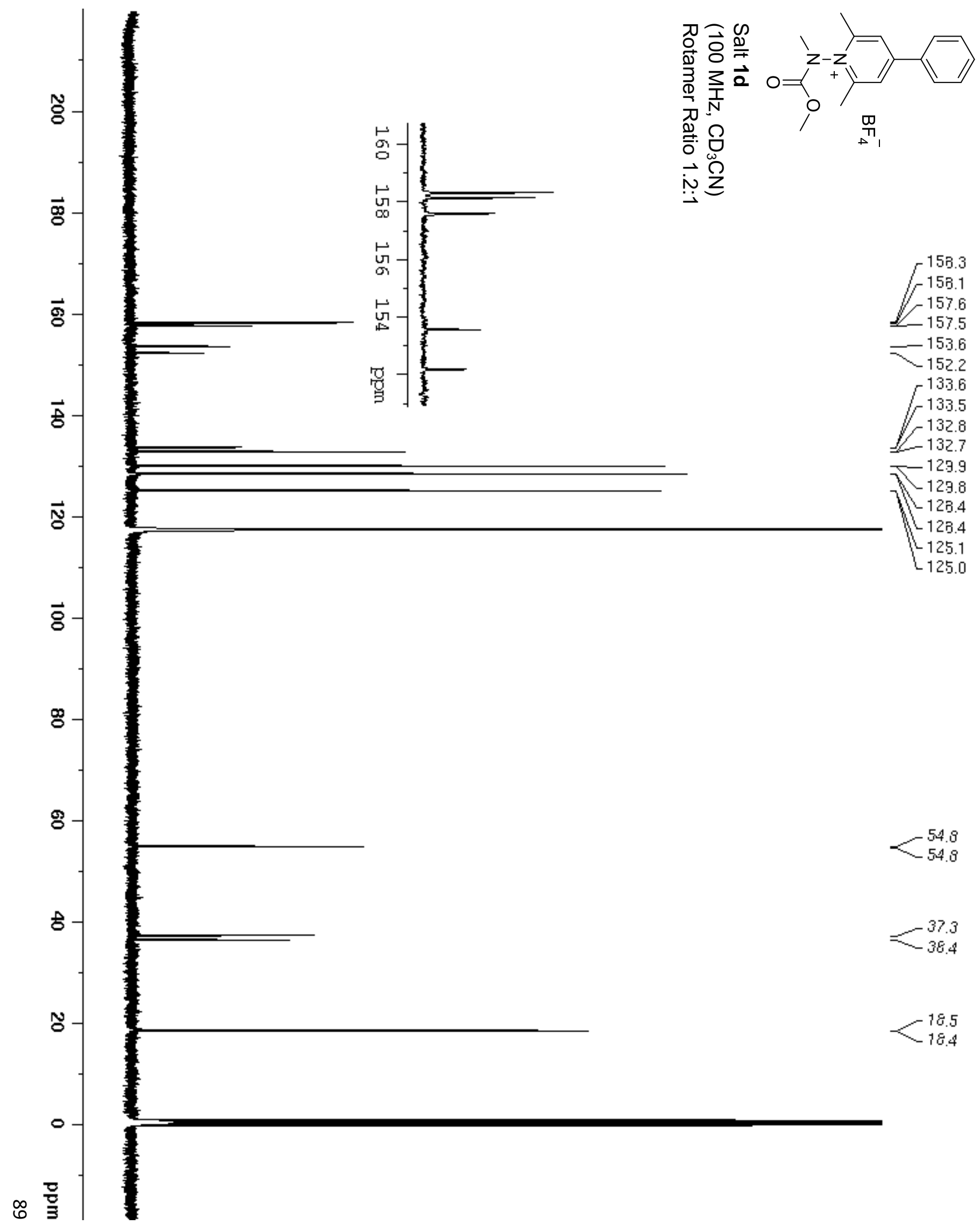

